\title{
Zgodność z Konstytucją niektórych przepisów ustawy o Krajowej Radzie Sądownictwa oraz ustawy Kodeks postępowania cywilnego ${ }^{1}$
}

\begin{abstract}
Conformity to the Constitution of some provisions of the Act on National Council of the Judiciary and the Code of Civil Procedure: The draft Sejm's position regards an application of the National Council of the Judiciary, addressed to Constitutional Tribunal, in which the Council applied for determination of conformity to the Constitution of some provisions of the Act on National Council of the Judiciary. It was stated that some provisions, indicated in the application, do not conform to the Constitution, inter alia regarding the possibility to appeal from some resolutions of the National Council of the Judiciary, or allowing to suspend the power of the President of the Republic of Poland to appoint a judge. Moreover it was claimed that the rule referring to appointing a judicial member of the National Council of the Judiciary by the Sejm conforms to the Constitution.
\end{abstract}

\footnotetext{
Keywords: National Council of the Judiciary, judges, Sejm, public civil, Constitutional Tribunal

Słowa kluczowe: Krajowa Rada Sądownictwa, sędziowie, Sejm, służba publiczna, Trybunał Konstytucyjny
}

Na podstawie art. 69 ust. 2 w związku z art. 42 pkt 3 ustawy z dnia 30 listopada 2016 r. o organizacji i trybie postępowania przed Trybunałem Konstytucyjnym (Dz. U. 19 grudnia 2016, poz. 2072), w imieniu Sejmu Rzeczypospolitej Polskiej przedkładam wyjaśnienia w sprawie wniosku Krajowej Rady Sądownictwa z 22 listopada 2018 r. (sygn. akt K 12/18), jednocześnie wnosząc o stwierdzenie, że:

1 Projekt stanowiska sporządzony 21 grudnia 2018 r., sygn. akt K 12/18; BAS-WAKU 2833/18. 
- art. 9a ust. 1 ustawy z dnia 12 maja 2011 r. o Krajowej Radzie Sądownictwa (Dz. U. 2018, poz. 389, ze zm.) jest zgodny z art. 186 ust. 1 oraz z art. 187 ust. 1 pkt 2 i ust. $4 \mathrm{w}$ związku z art. 2, art. 10 ust. 1 i art. 173 Konstytucji,

- art. 44 ust. 1 ustawy powołanej w punkcie pierwszym w zakresie, w jakim dopuszcza odwołanie od uchwał Krajowej Rady Sądownictwa w sprawach, o których mowa w art. 3 ust. 1 pkt 1 i 2 tej ustawy, jest niezgodny $z$ art. 2, art. 10, art. 144 ust. 3 pkt 17, art. 173, art. 178, art. 179 i art. 186 ust. 1 Konstytucji,

- $\quad$ art. 44 ust. 1a ustawy powołanej w punkcie pierwszym jest niezgodny z art. 2, art. 10, art. 60, art. 144 ust. 3 pkt 17, art. 173, art. 178, art. 179 i art. 184 Konstytucji,

- $\quad$ art. 44 ust. 3 ustawy powołanej w punkcie pierwszym w związku z art. $388 \$ 1$ ustawy z dnia 17 listopada 1964 r. - Kodeks postępowania cywilnego (Dz. U. 2018, poz. 1360, ze zm.) w zakresie, w jakim umożliwia wstrzymanie uprawnień Prezydenta Rzeczypospolitej Polskiej do powołania sędziego, jest niezgodny $\mathrm{z}$ art. 2, art. 7, art. 10, art. 144 ust. 3 pkt 17, art. 173, art. 178, art. 179 i art. 184 Konstytucji,

- art. 44 ust. 4 ustawy powołanej w punkcie pierwszym jest niezgodny z art. 2, art. 7, art. 10, art. 60, art. 173, art. 178, art. 179 i art. 186 ust. 1 Konstytucji.

Sejm wnosi także o umorzenie postępowania w pozostałym zakresie na podstawie art. 59 ust. 1 pkt 2 ustawy z dnia 30 listopada 2016 r. o organizacji i trybie postępowania przed Trybunałem Konstytucyjnym (Dz. U. poz. 2072) ze względu na niedopuszczalność wydania wyroku.

\section{Uzasadnienie}

\section{Przedmiot kontroli i zarzuty wnioskodawcy}

1. W dniu 30 listopada 2018 r. do Kancelarii Sejmu wpłynęło zawiadomienie Prezesa Trybunału Konstytucyjnego o wszczęciu postępowania przed Trybunałem Konstytucyjnym w sprawie wniosku Krajowej Rady Sądownictwa z 22 listopada 2018 r. (sygn. akt K 12/18).

Przedmiotem kontroli są następujące przepisy: art. 9a ustawy z dnia 12 maja 2011 r. o Krajowej Radzie Sądownictwa (Dz. U. 2018, poz. 389, ze zm., dalej: uKRS lub ustawa o KRS); art. 11a uKRS; art. 11b uKRS; art. 11c uKRS; art. 11d uKRS; art. 11e uKRS; art. 44 ust 1 uKRS w zakresie, w jakim dopuszcza odwołanie od uchwał Krajowej Rady Sądownictwa w sprawach, o których mowa w art. 3 ust. 1 pkt 1 i 2 uKRS; art. 44 ust. 1a uKRS; 44 ust. 3 uKRS, w zakresie, w jakim do postępowania przed Naczelnym Sądem Administracyjnym nakazuje stosowanie przepisów ustawy z dnia 17 listopada 1964 r - Kodeks postępowania cywilnego o skardze kasacyjnej; art. $388 \$ 1$ ustawy z dnia 17 listopada 1964 r. - Kodeks 
postępowania cywilnego (Dz. U. 2018, poz. 1360, ze zm., dalej: k.p.c.) w związku $\mathrm{z}$ art. 44 ust. 3 uKRS oraz art. 44 ust. 4 uKRS.

Sejm, będąc organem, który wydał zakwestionowane akty normatywne, jako uczestnik postępowania jest zobowiązany do złożenia wyjaśnień i przedstawienia stanowiska w sprawie (art. 69 ust. 2 w związku z art. 42 pkt 3 ustawy z dnia 30 listopada 2016 r. o organizacji i trybie postępowania przed Trybunałem Konstytucyjnym, Dz. U. poz. 2072, dalej: ustawa o TK).

2. Krajowa Rada Sądownictwa (dalej: wnioskodawca), na podstawie uchwały nr 577/2018 z 22 listopada 2018 r. wystąpiła z wnioskiem o stwierdzenie, że:

„1) art. 9a, art. 11a, art. 11b, art. 11c, art. 11d i art. 11e ustawy z dnia 12 maja 2011 r. o Krajowej Radzie Sądownictwa (Dz. U. 2018, poz. 389, ze zm.) są niezgodne z art. 187 ust. 1 pkt 2 i ust. 4 w zw. z art. 2, art. 10 ust. 1 i art. 173 Konstytucji oraz są niezgodne $\mathrm{z}$ art. 186 ust. 1 Konstytucji RP;

2) art. 44 ust. 1 ustawy z dnia 12 maja 2011 r. o Krajowej Radzie Sądownictwa (Dz. U. 2018, poz. 389, ze zm.) w zakresie, w jakim dopuszcza odwołanie od uchwał Krajowej Rady Sądownictwa w sprawach, o których mowa w art. 3 ust. 1 pkt 1 i 2 tej ustawy, jest niezgodny z art. 2, art. 10, art. 144 ust. 3 pkt 17, art. 173, art. 178, art. 179 i art. 186 ust. 1 Konstytucji RP;

3) art. 44 ust. 1a ustawy z dnia 12 maja 2011 r. o Krajowej Radzie Sądownictwa (Dz. U. 2018, poz. 389, ze zm.) jest niezgodny z art. 2, art. 10, art. 60, art. 144 ust. 3 pkt 17, art. 173, art. 178, art. 179 i art. 184 Konstytucji RP;

4) art. 44 ust. 3 ustawy z dnia 12 maja 2011 r. o Krajowej Radzie Sądownictwa (Dz. U. 2018, poz. 389, ze zm.) w zakresie, w jakim do postępowania przed Naczelnym Sądem Administracyjnym nakazuje stosowanie przepisów ustawy z dnia 17 listopada 1964 r. - Kodeks postępowania cywilnego (Dz. U. 2018, poz. 155; 2017, poz. 2491 oraz 2018, poz. 5 i 138) o skardze kasacyjnej, jest niezgodny z art. 2, art. 7, art. 10, art. 144 ust. 3 pkt 17, art. 173, art. 178, art. 179, art. 184 Konstytucji RP;

5) art. $388 \$ 1$ ustawy z dnia 17 listopada 1964 r. - Kodeks postępowania cywilnego (Dz. U. 2018, poz. 1360, ze zm.) w związku z art. 44 ust. 3 ustawy z dnia 12 maja 2011 r. o Krajowej Radzie Sądownictwa (Dz. U. 2018, poz. 389, ze zm.) w zakresie, w jakim umożliwia wstrzymanie uprawnień Prezydenta Rzeczypospolitej Polskiej do powołania sędziego, jest niezgodny z art. 2, art. 7, art. 10, art. 144 ust. 3 pkt 17, art. 173, art. 178 oraz art. 179 Konstytucji RP, art. 184 Konstytucji RP;

6) art. 44 ust. 4 ustawy z dnia 12 maja 2011 r. o Krajowej Radzie Sądownictwa (Dz. U. 2018, poz. 389, ze zm.) jest niezgodny z art. 2, art. 7, art. 10, art. 60, art. 173, art. 178, art. 179 i art. 186 ust. 1 Konstytucji RP” (wniosek zawarty w uchwale nr 577/2018 Krajowej Rady Sądownictwa z dnia 22 listopada 2018 r. w sprawie skierowania wniosku do Trybunału Konstytucyjnego o zbadanie zgodności z Konstytucją Rzeczypospolitej Polskiej ustawy z dnia 12 maja 2011 r. o Krajowej Radzie Sądownictwa (Dz. U. 2018, poz. 389, ze zm.) oraz art. 388 
$\$ 1$ ustawy z dnia 17 listopada 1964 r. - Kodeks postępowania cywilnego (Dz. U. 2018, poz. 1360, ze zm.), dalej: wniosek.

3. Kwestionowane przepisy mają następujące brzmienie:

Artykuł 9a uKRS stanowi: „1. Sejm wybiera spośród sędziów Sądu Najwyższego, sądów powszechnych, sądów administracyjnych i sądów wojskowych piętnastu członków Rady na wspólną czteroletnią kadencję.

2. Dokonując wyboru, o którym mowa w ust. 1, Sejm, w miarę możliwości, uwzględnia potrzebę reprezentacji w Radzie sędziów poszczególnych rodzajów i szczebli sądów.

3. Wspólna kadencja nowych członków Rady wybranych spośród sędziów rozpoczyna się z dniem następującym po dniu, w którym dokonano ich wyboru. Członkowie Rady poprzedniej kadencji pełnią swoje funkcje do dnia rozpoczęcia wspólnej kadencji nowych członków Rady".

Artykuł 11a uKRS stanowi: „1. Marszałek Sejmu, nie wcześniej niż na sto dwadzieścia i nie później niż na dziewięćdziesiąt dni przed upływem kadencji członków Rady wybranych spośród sędziów obwieszcza w Dzienniku Urzędowym Rzeczypospolitej Polskiej «Monitor Polski» o rozpoczęciu procedury zgłaszania kandydatów na członków Rady.

2. Podmiotami uprawnionymi do zgłoszenia kandydata na członka Rady jest grupa co najmniej:

1) dwóch tysięcy obywateli Rzeczypospolitej Polskiej, którzy ukończyli osiemnaście lat, mają pełną zdolność do czynności prawnych i korzystają z pełni praw publicznych;

2) dwudziestu pięciu sędziów, $z$ wyłączeniem sędziów w stanie spoczynku.

3. Jedno zgłoszenie może dotyczyć wyłącznie jednego kandydata na członka Rady. Podmioty, o których mowa w ust. 2, mogą złożyć więcej niż jedno zgłoszenie.

4. Kandydata na członka Rady zgłasza się Marszałkowi Sejmu, w terminie trzydziestu dni od dnia obwieszczenia, o którym mowa w ust. 1.

5. Zgłoszenie kandydata obejmuje informacje o kandydacie, pełnionych dotychczas funkcjach i działalności społecznej oraz innych istotnych zdarzeniach mających miejsce w trakcie pełnienia przez kandydata urzędu sędziego. Do zgłoszenia dołącza się zgodę sędziego na kandydowanie.

6. Marszałek Sejmu, w terminie trzech dni od dnia otrzymania zgłoszenia kandydata, zwraca się na piśmie do prezesa sądu właściwego dla zgłoszonego kandydata, a w przypadku gdy zgłoszenie dotyczy prezesa:

1) sądu rejonowego, sądu okręgowego albo wojskowego sądu garnizonowego do prezesa sądu wyższej instancji,

2) sądu apelacyjnego, wojewódzkiego sądu administracyjnego albo wojskowego sądu okręgowego - do wiceprezesa albo zastępcy prezesa tego sądu

- z wnioskiem o sporządzenie i przekazanie, w terminie siedmiu dni od dnia otrzymania wniosku, informacji obejmującej dorobek orzeczniczy kandydata, 
w tym doniosłe społecznie lub precedensowe orzeczenia, i istotne informacje dotyczące kultury urzędowania, przede wszystkim ujawnione podczas wizytacji i lustracji.

7. W przypadku, gdy informacja, o której mowa w ust. 6, nie zostanie sporządzona w terminie, o którym mowa w ust. 6, Marszałek Sejmu zwraca się na piśmie do kandydata na członka Rady o sporządzenie przez niego tej informacji, w terminie siedmiu dni od dnia otrzymania wniosku Marszałka Sejmu. Kopię sporządzonej przez siebie informacji kandydat na członka Rady przekazuje, odpowiednio, prezesowi sądu właściwego dla zgłoszonego kandydata, prezesowi sądu wyższej instancji albo wiceprezesowi albo zastępcy prezesa sądu apelacyjnego, wojewódzkiego sądu administracyjnego albo wojskowego sądu okręgowego.

8. W przypadku niesporządzenia informacji, o której mowa w ust. 6, przez kandydata na członka Rady w terminie, o którym mowa w ust. 7, Marszałek Sej$\mathrm{mu}$ odmawia przyjęcia zgłoszenia. Postanowienie w tej sprawie wraz z uzasadnieniem doręcza się niezwłocznie pełnomocnikowi oraz kandydatowi na członka Rady.

9. Informację, o której mowa w ust. 6, Marszałek Sejmu załącza do zgłoszenia kandydata".

Artykuł 11b uKRS stanowi: „1. Zgłoszenia kandydata dokonuje na piśmie pełnomocnik. Pełnomocnikiem jest osoba wskazana w pisemnym oświadczeniu pierwszych piętnastu osób z wykazu.

2. Do zgłoszenia kandydata przez podmiot, o którym mowa w art. 11a ust. 2 pkt 1, załącza się wykaz obywateli popierających zgłoszenie, zawierający ich imiona, nazwiska, adresy zamieszkania, numery ewidencyjne PESEL i własnoręcznie złożone podpisy.

3. W przypadku wątpliwości, co do prawidłowości złożenia wymaganej liczby podpisów Marszałek Sejmu, w terminie trzech dni od dnia otrzymania zgłoszenia, zwraca się na piśmie do Państwowej Komisji Wyborczej o stwierdzenie, czy złożono wymaganą liczbę podpisów.

4. Państwowa Komisja Wyborcza w postępowaniu stwierdza, czy złożono wymaganą liczbę podpisów w terminie czternastu dni od dnia otrzymania pisma Marszałka Sejmu.

5. Jeżeli po przeprowadzeniu postępowania, o którym mowa w ust. 4, okaże się, że liczba prawidłowo złożonych podpisów przez obywateli popierających zgłoszenie jest mniejsza niż wymagana, Marszałek Sejmu odmawia przyjęcia zgłoszenia. Postanowienie $\mathrm{w}$ tej sprawie wraz z uzasadnieniem doręcza się niezwłocznie pełnomocnikowi.

6. Postanowienie może być zaskarżone przez pełnomocnika do Sądu Najwyższego w terminie trzech dni od dnia doręczenia. Sąd Najwyższy rozpoznaje skargę w terminie trzech dni w postępowaniu nieprocesowym, w składzie trzech sędziów. W wyniku rozpoznania skargi Sąd Najwyższy zaskarżone postano- 
wienie zmienia albo utrzymuje w mocy. Od postanowienia Sądu Najwyższego nie przysługuje środek prawny. W przypadku nierozpoznania skargi przez Sąd Najwyższy w terminie trzech dni postępowanie przed Sądem Najwyższym umarza się z mocy prawa, a postanowienie Marszałka Sejmu odmawiające przyjęcia zgłoszenia jest wiążące.

7. Do zgłoszenia kandydata przez podmiot, o którym mowa w art. 11a ust. 2 pkt 2, załącza się wykaz sędziów popierających zgłoszenie, zawierający ich imiona, nazwiska, miejsca służbowe, numery ewidencyjne PESEL i własnoręcznie złożone podpisy.

8. Marszałek Sejmu, w terminie trzech dni od dnia otrzymania zgłoszenia kandydata przez podmiot, o którym mowa w art. 11a ust. 2 pkt 2, zwraca się na piśmie do Ministra Sprawiedliwości o potwierdzenie posiadania przez osoby popierające zgłoszenie statusu sędziego. Minister Sprawiedliwości potwierdza posiadanie przez osoby popierające zgłoszenie statusu sędziego w terminie trzech dni od dnia otrzymania pisma Marszałka Sejmu. Przepisy ust. 5 i 6 stosuje się odpowiednio.

9. Wzór zgłoszenia kandydata oraz wzory wykazu obywateli i wykazu sędziów popierających zgłoszenie kandydata na członka Rady ustala, w drodze zarządzenia, Marszałek Sejmu. Zarządzenie Marszałka Sejmu podlega obwieszczeniu w Dzienniku Urzędowym Rzeczypospolitej Polskiej »Monitor Polski«”.

Artykuł 11c uKRS stanowi: „Zgłoszenia kandydatów dokonane zgodnie $\mathrm{z}$ art. 11a i art. 11b Marszałek Sejmu niezwłocznie przekazuje posłom i podaje do publicznej wiadomości, z wyłączeniem załączników”.

Artykuł 11d uKRS stanowi: „1. Marszałek Sejmu zwraca się do klubów poselskich o wskazanie, w terminie siedmiu dni, kandydatów na członków Rady.

2. Klub poselski wskazuje, spośród sędziów, których kandydatury zostały zgłoszone w trybie art. 11a, nie więcej niż dziewięciu kandydatów na członków Rady.

3. Jeżeli łączna liczba kandydatów wskazanych przez kluby poselskie jest mniejsza niż piętnaście, Prezydium Sejmu wskazuje, spośród kandydatów zgłoszonych w trybie art. 11a, kandydatów w liczbie brakującej do piętnastu.

4. Właściwa komisja sejmowa ustala listę kandydatów wybierając, spośród kandydatów wskazanych w trybie ust. 2 i 3, piętnastu kandydatów na członków Rady, z zastrzeżeniem, że na liście uwzględnia się co najmniej jednego kandydata wskazanego przez każdy klub poselski, który działał w terminie sześćdziesięciu dni od dnia pierwszego posiedzenia Sejmu kadencji w trakcie której jest dokonywany wybór, o ile kandydat ten został wskazany przez klub w ramach wskazania, o którym mowa w ust. 2.

5. Sejm wybiera członków Rady na wspólną czteroletnią kadencję, na najbliższym posiedzeniu Sejmu, większością $3 / 5$ głosów w obecności co najmniej połowy ustawowej liczby posłów, głosując na listę kandydatów, o której mowa w ust. 4.

6. W przypadku niedokonania wyboru członków Rady w trybie określonym w ust. 5, Sejm wybiera członków Rady bezwzględną większością głosów w obec- 
ności co najmniej połowy ustawowej liczby posłów, głosując na listę kandydatów, o której mowa w ust. 4.

7. Jeżeli w wyniku zastosowania trybu, o którym mowa w ust. 1-6, nie zostanie wybranych piętnastu członków Rady, stosuje się odpowiednio przepisy art. 11a-11d".

Artykuł 11e uKRS stanowi: „1. Jeżeli przed upływem kadencji członka Rady wybranego spośród sędziów zajdzie potrzeba ponownego obsadzenia mandatu członka Rady, Marszałek Sejmu niezwłocznie obwieszcza w Dzienniku Urzędowym Rzeczypospolitej Polskiej »Monitor Polski« o rozpoczęciu procedury zgłaszania kandydatów na członka Rady w związku z potrzebą ponownego obsadzenia mandatu. Przepisy art. 11a ust. 2-9, art. 11b i art. 11c stosuje się odpowiednio.

2. W przypadku, o którym mowa w ust. 1, do wyboru członka Rady stosuje się przepisy art. 9a ust. 1 i 2 oraz art. 11d.

3. Kadencja członka Rady wybranego w związku z potrzebą ponownego obsadzenia mandatu upływa $\mathrm{z}$ dniem zakończenia kadencji członków Rady wybranych spośród sędziów”.

Artykuł 44 uKRS stanowi: „1. Uczestnik postępowania może odwołać się do Sądu Najwyższego z powodu sprzeczności uchwały Rady z prawem, o ile przepisy odrębne nie stanowią inaczej. Odwołanie nie przysługuje w sprawach określonych w art. 3 ust. 2 pkt 2 niniejszej ustawy.

1a. W sprawach indywidualnych dotyczących powołania do pełnienia urzędu na stanowisku sędziego Sądu Najwyższego odwołanie przysługuje do Naczelnego Sądu Administracyjnego. W sprawach tych odwołanie do Sądu Najwyższego nie przysługuje. Odwołanie do Naczelnego Sądu Administracyjnego nie może być oparte na zarzucie niewłaściwej oceny spełniania przez kandydatów kryteriów uwzględnianych przy podejmowaniu rozstrzygnięcia w przedmiocie przedstawienia wniosku o powołanie do pełnienia urzędu sędziego na stanowisku sędziego Sądu Najwyższego.

[...]

3. Do postępowania przed Sądem Najwyższym i Naczelnym Sądem Administracyjnym stosuje się przepisy ustawy z dnia 17 listopada 1964 r. - Kodeks postępowania cywilnego (Dz. U. z 2018 r. poz. 155, z 2017 r. poz. 2491 oraz z 2018 r. poz. 5 i 138) o skardze kasacyjnej. Przepisu art. $87^{1}$ tej ustawy nie stosuje się.

4. W sprawach indywidualnych dotyczących powołania do pełnienia urzędu na stanowisku sędziego Sądu Najwyższego uchylenie przez Naczelny Sąd Administracyjny uchwały Krajowej Rady Sądownictwa o nieprzedstawieniu wniosku o powołanie do pełnienia urzędu sędziego Sądu Najwyższego jest równoznaczne z przyjęciem zgłoszenia uczestnika postępowania, który wniósł odwołanie, kandydatury na wolne stanowisko sędziowskie w Sądzie Najwyższym, co do którego w dniu wydania orzeczenia przez Naczelny Sąd Administracyjny postępowanie przed Krajową Radą Sądownictwa nie zostało zakończone, a w przypadku braku 
takiego postępowania, na kolejne wolne stanowisko sędziowskie w Sądzie Najwyższym objęte obwieszczeniem".

Artykuł $388 \$ 1$ k.p.c. stanowi: „W razie wniesienia skargi kasacyjnej, gdyby na skutek wykonania orzeczenia stronie mogła być wyrządzona niepowetowana szkoda, sąd drugiej instancji może wstrzymać wykonanie zaskarżonego orzeczenia do czasu ukończenia postępowania kasacyjnego lub uzależnić wykonanie tego orzeczenia - a w razie oddalenia apelacji także orzeczenia sądu pierwszej instancji - od złożenia przez powoda stosownego zabezpieczenia. Postanowienie może być wydane na posiedzeniu niejawnym".

4. Wnioskodawca wskazał problem konstytucyjny w odniesieniu do zarzutów zawartych w każdym z sześciu punktów petitum wniosku, a następnie przedstawił zarzuty wraz z uzasadnieniem.

4.1. Uzasadniając zarzuty wyartykułowane w punkcie pierwszym petitum wniosku, wnioskodawca podkreśla, że „budzącym największe wątpliwości natury konstytucyjnej, a przez to kluczowym zagadnieniem podnoszonym w wypowiedziach kontestujących obecnie obowiązujące rozwiązania ustawy o KRS, jest sposób ukształtowania przez ustawodawcę sposobu powoływania sędziów-członków Krajowej Rady Sądownictwa, dlatego też Rada zdecydowała się na zainicjowanie kontroli przepisów regulujących te właśnie zagadnienia. W ocenie KRS, rysuje się w przedmiotowej sprawie problem konstytucyjny, którego istota sprowadza się do oceny, czy w świetle normatywnych treści zawartych w powołanych w przedmiotowej sprawie jako wzorce kontroli art. 187 ust. 1 pkt 2 i ust. 4 W ZW. z art. 2, art. 10 ust. 1 i art. 173 Konstytucji oraz art. 186 ust. 1 Konstytucji RP dopuszczalne jest unormowanie przewidujące powoływanie sędziów wchodzących w skład KRS przez inny podmiot niż samo środowisko sędziowskie. [...] W ocenie KRS zachodzi więc konieczność uzyskania rozstrzygnięcia Trybunału Konstytucyjnego, bowiem nie można a limine odrzucić argumentacji przedstawianej przez tę część doktryny, która opowiada się za przyjęciem, że w świetle Konstytucji RP jedynie dopuszczalne jest ustawowe unormowanie przewidujące powoływanie sędziów wchodzących w skład KRS przez samo środowisko sędziowskie" (wniosek, s. 28).

4.2. Uzasadniając zarzuty wyartykułowane w punkcie drugim petitum wniosku, wnioskodawca wskazuje na problemy konstytucyjne wynikające z zaskarżonej normy zrekonstruowanej z art. 44 ust. 1 uKRS, które „obejmują dysfunkcjonalność stworzonej instytucji, ingerencję w zasadę podziału i równowagi władzy poprzez dopuszczenie niedozwolonego wpływu władzy sądowniczej na proces nominacji sędziów, a przez to naruszenie zasady niezależności sądów i niezależności sędziów" (ibidem, s. 35).

Wnioskodawca podnosi, że w obowiązującej ustawie o KRS, w przeciwieństwie do nieobowiązującego już art. 13 ust. 5 uKRS, „nie uregulowano kwestii związanych z orzeczeniami, które wydaje Sąd Najwyższy po rozpoznaniu sprawy w wyniku odwołania od uchwały Rady. W związku z tym odpowiednie zastoso- 
wanie będą miały art. $398^{14}$ k.p.c., stanowiący podstawę oddalenia skargi kasacyjnej oraz art. $398^{15}$ k.p.c., dotyczący uchylenia zaskarżonego orzeczenia i przekazania sprawy do ponownego rozpoznania, w tym przypadku Krajowej Radzie Sądownictwa. Wyłączone jest stosowanie art. $398^{16}$ k.p.c., dającego Sądowi Najwyższemu podstawę do wydania wyroku reformatoryjnego" (ibidem, s. 34).

W przypadku uwzględnienia odwołania, Sąd Najwyższy uchyla zaskarżoną uchwałę w całości lub w części i przekazuje sprawę do ponownego rozpoznania Krajowej Radzie Sądownictwa.

W orzecznictwie Sądu Najwyższego przyjmuje się, że przedmiotem kontroli jest formalny aspekt dostępu do służby, dotyczący przestrzegania przez KRS przyjętych kryteriów i procedur postępowania, nie zaś sama ocena kwalifikacji czy predyspozycji danej osoby, ponieważ mogłoby to naruszać uprawnienia i kompetencje KRS wynikające $\mathrm{z}$ art. 179 Konstytucji i $\mathrm{z}$ art. 3 ust. 1 pkt 1 i 2 uKRS (wyroki SN z: 13 lipca 2017 r., sygn. akt III KRS 17/17; 7 marca 2017 r., sygn. akt III KRS 3/17; 26 stycznia 2017 r., sygn. akt III KRS 37/16).

Jak wskazuje wnioskodawca, „Sąd Najwyższy zastrzega, że ocena doboru kryteriów oraz znaczenie przywiązywane do poszczególnych kryteriów przy ocenie kandydatów na stanowiska sędziowskie pozostają poza zakresem kompetencji Sądu Najwyższego do kontroli zgodności uchwał Rady z prawem (art. 44 ust. 1 ustawy o Krajowej Radzie Sądownictwa), chyba że naruszają podstawowe zasady prawne lub opierają się na zastosowaniu niedozwolonych kryteriów oceny. [...] Kierunek rozwoju poglądu Sądu Najwyższego świadczy o tym, że nie wyklucza on, że w określonych przypadkach mógłby ocenić zasadność i sposób wyznaczenia kryteriów dla kandydatów na urząd sędziego, a takie działanie zbliża się niebezpiecznie do ingerencji w konstytucyjnie ukształtowany status Krajowej Rady Sądownictwa w zakresie dotyczącym procedury powoływania sędziów" (ibidem, s. 35).

Wnioskodawca wskazuje na problemy konstytucyjne wynikające z zaskarżonego art. 44 ust. 1 uKRS, w zakresie, w jakim dopuszcza odwołanie od uchwał Krajowej Rady Sądownictwa w sprawach, o których mowa w art. 3 ust. 1 pkt 1 i 2 uKRS. Chodzi mianowicie o „dysfunkcjonalność stworzonej instytucji, ingerencję w zasadę podziału i równowagi władz poprzez dopuszczenie niedozwolonego wpływu władzy sądowniczej na proces nominacji sędziów, a przez to naruszenie zasady niezależności sądów i niezależności sędziów" (ibidem, s. 35).

Wnioskodawca zarzuca, że analizowana instytucja odwołania od uchwał KRS do Sądu Najwyższego, „mimo że została ukształtowana w wyniku wyroku TK zobowiązującego do zapewnienia kontroli procedur dostępu do służby publicznej na jednakowych zasadach, jest rozwiązaniem dysfunkcjonalnym, przez co utrudnia realizację konstytucyjnych uprawnień organów władzy publicznej. Praktyka pokazuje, że w znakomitej większości przypadków odwołania są oddalane, a Sąd nie dysponuje normatywnymi narzędziami do dokonania właściwej weryfikacji tylko pod względem dopełnienia kwestii formalnych bez wchodzenia 
w kwestie merytoryczne dotyczące kryteriów oceny sędziów. W ten sposób orzekanie w sprawie może być daleko uznaniowe, a nawet arbitralne. Również zakres kognicji Sądu Najwyższego, zakreślony przez TK w wyroku o sygn. SK 57/05, ogranicza w sposób znaczący skuteczność i celowość weryfikacji realizacji prawa dostępu do służby publicznej. Oznacza to, że w istocie - mimo istnienia formalnej procedury - mamy do czynienia z instytucją dysfunkcjonalną i pozorną, a taki stan rzeczy jest niezgodny z art. 2 i art. 7 Konstytucji RP” (ibidem, s. 36).

Zdaniem wnioskodawcy, „część aktualnych wypowiedzi SN świadczy o tym, że w pewnych przypadkach sąd ten - w ramach kontroli spełnienia wymogów konstytucyjnych - byłby zdolny do weryfikacji kryteriów oceny kandydatów na sędziów oraz sposobu ich przypisania w konkretnej sprawie. Wejście w ocenę merytoryczną decyzji Krajowej Rady Sądownictwa bez wyraźnej podstawy prawnej jest naruszeniem zasady legalizmu (art. 7 Konstytucji RP), a także ingeruje w konstytucyjnie ukształtowane kompetencje KRS do wnioskowania o powołanie sędziów, a przez to wpływa na realizację kompetencji do powoływania sędziów przez Prezydenta RP. Dzięki odwołaniu Sąd Najwyższy w pewnych wypadkach może bowiem narzucić określony sposób działania KRS, gdyż w orzecznictwie SN pojawia się nierzadko stanowisko, że gdy Sąd ten przekaże Radzie sprawę do ponownego rozpoznania, Rada jest związana stanowiskiem sądu, zgodnie z przepisami Kodeksu postępowania cywilnego. To oznacza, że możliwość odwołania od uchwał KRS w zakwestionowanym zakresie stanowi nieadekwatną i nieproporcjonalną ingerencję $\mathrm{w}$ konstytucyjne kompetencje Prezydenta RP i Krajowej Rady Sądownictwa. Przez to naruszona jest nie tylko wynikająca $\mathrm{z}$ art. 2 Konstytucji zasada proporcjonalności, ale także zasada podziału i równowagi władzy (art. 10 Konstytucji RP) i konstytucyjne przepisy o powoływaniu sędziów (art. 179 i art. 144 ust. 3 pkt 17 Konstytucji RP)" (ibidem, s. 36-37).

Wnioskodawca podkreśla, że przyznanie prawa do analizowanego odwołania od uchwały KRS „zostało oparte na przekonaniu, że uchwała KRS powoduje, że mamy do czynienia ze sprawą z zakresu administracji publicznej. Tymczasem, nie można o postępowaniu przed Krajową Radą Sądownictwa mówić jako o postępowaniu przed organem administracji publicznej. KRS nie jest organem administracji publicznej, ale jest konstytucyjnym organem państwa nienależącym do władzy wykonawczej i niewykonującym zadań z zakresu administracji publicznej. Stąd wprowadzenie uproszczenia w tym zakresie, przez które uzasadnia się określone działania legislacyjne, stoi w sprzeczności z konstytucyjną pozycją Krajowej Rady Sądownictwa. Sprowadzenie tego organu do organu administracyjnego, a postępowania przed nim do postępowania administracyjnego (mimo że ustawa wyraźnie wskazuje, że przepisów Kodeksu postępowania administracyjnego się w tym przypadku nie stosuje) narusza konstytucyjne przepisy o ustroju KRS i powoduje, że ogranicza się jej możliwość działania w ramach stania na straży niezależności sądów i niezawisłości sędziów” (ibidem, s. 37). 
4.3. Uzasadniając zarzuty wyartykułowane w punkcie trzecim petitum wniosku, wnioskodawca wskazuje na problemy konstytucyjne wynikające z art. 44 ust. 1a uKRS, które „obejmują dysfunkcjonalność stworzonej instytucji, naruszenie określoności prawa, a także są związane z ingerencją w zasadę podziału i równowagi władzy poprzez dopuszczenie niedozwolonego wpływu władzy sądowniczej na proces nominacji sędziów, a przez to naruszenie zasady niezależności sądów i niezależności sędziów. Dodatkowo przepisy budzą wątpliwość co do ich zgodności z konstytucyjną pozycją Naczelnego Sądu Administracyjnego i jego kompetencjami” (ibidem, s. 39).

Wnioskodawca argumentuje, że jeśli ustawodawca konstytucyjny powierzył daną kompetencję określonym podmiotom, a mianowicie kompetencję KRS do przedstawienia wniosku oraz kompetencję Prezydentowi RP do dokonania aktu powołania, to należy z tej perspektywy oceniać dopuszczalny zakres regulacji ustawowej tej materii. Stworzenie procedury odwoławczej do NSA włącza ten sąd w proces decyzyjny związany z powoływaniem sędziów. Ponieważ zakres odwołania jest sformułowany w sposób nieostry, co powoduje, że może być doprecyzowany w procesie stosowania prawa, w rezultacie sprawia, że taka regulacja stanowi nieproporcjonalną ingerencję w konstytucyjną prerogatywę Prezydenta RP i w uprawnienia KRS do przedkładania wniosku w sprawie powołania na urząd sędziowski.

Wnioskodawca powołuje się na pierwsze postanowienia NSA o zawieszeniu wykonania uchwał, które „pokazują, że w praktyce przepis ten może mieć charakter hamujący konstytucyjne procedury powoływania sędziów, przez co dochodzi do dysfunkcji systemu organów władzy publicznej. Wskazane działanie nie jest proporcjonalne i nie realizuje założonego celu, którym miała być ochrona prawa dostępu do służby publicznej na równych zasadach" (ibidem, s. 40).

Wnioskodawca podnosi, że „sposób sformułowania przepisu nie daje odpowiedzi, w jaki sposób powinna być przez Naczelny Sąd Administracyjny badana uchwała KRS, aby nie naruszać konstytucyjnego podziału kompetencji organów. To wprowadza poczucie niepewności prawnej i brak stabilności systemu prawa. Daje też szeroki margines swobody sądowi administracyjnemu do działania, co powoduje ryzyko, że w pewnych przypadkach będzie on podejmował rozstrzygnięcia bez podstawy prawnej. Z tego względu wskazane przepisy należy ocenić jako naruszające art. 2 i art. 7 Konstytucji RP” (ibidem).

Wnioskodawca zarzuca, że włączenie NSA w proces powoływania sędziów sprawia, że art. 44 ust. la uKRS stanowi nadmierną ingerencję w zasadę podziału i równowagi władzy, a także niewspółmiernie ingeruje w zasadę niezależności sądów, które zostają włączone, bez podstawy konstytucyjnej, w ustrojowy proces powoływania sędziów.

Ponadto wnioskodawca zarzuca, że art. 44 ust. 1a uKRS „różnicuje środki weryfikacji uchwał KRS dotyczących przedstawiania kandydatów na stanowisko sędziego w zależności od tego, czy mamy do czynienia z kandydatem do Sądu 
Najwyższego, czy do innego sądu. W przypadku kandydatów do SN właściwy jest Naczelny Sąd Administracyjny, w pozostałych przypadkach odwołania rozpoznaje Sąd Najwyższy. Wprowadzanie różnych reżimów w tym zakresie stoi w sprzeczności z prawem dostępu do służby publicznej na jednakowych zasadach w kontekście jednakowych procedur weryfikacji aktów KRS. Przez to ustawodawca wprowadza różne standardy gwarancji proceduralnych w procesie powoływania sędziów, co stoi w sprzeczności z prawami konstytucyjnymi” (ibidem, s. 41).

Wnioskodawca twierdzi, że powierzenie weryfikacji uchwał KRS w zakresie wynikającym z art. 44 ust. 1a uKRS sądowi administracyjnemu czyni z postępowania przed KRS, dotyczącego wyłaniania kandydatów na sędziego, sui generis postępowanie administracyjne. Wnioskodawca nie zgadza się z przyjętą przez TK w sprawie o sygn. akt SK 57/06 wykładnią, że postępowanie to dotyczy spraw z zakresu administracji publicznej, a kwestia przedstawienia albo nieprzedstawienia kandydata na stanowisko sędziego Prezydentowi RP jest sprawą z zakresu administracji publicznej. W przeciwieństwie do tego poglądu wnioskodawca stwierdza, że kompetencje KRS w zakresie oceny kandydatów i ich przedstawiania Prezydentowi RP mają charakter ustrojowy, wobec czego art. 44 ust. 1a uKRS narusza przypisane sądom administracyjnym zadania, które wynikają z art. 184 Konstytucji.

4.4. Uzasadniając zarzuty wyartykułowane w punkcie czwartym petitum wniosku, wnioskodawca wskazuje na problemy konstytucyjne wynikające $\mathrm{z}$ art. 44 ust. 3 uKRS w zakresie, w jakim do postępowania przed Naczelnym Sądem Administracyjnym nakazuje stosowanie przepisów ustawy z dnia 17 listopada 1964 r. - Kodeks postępowania cywilnego (Dz. U. 2018, poz. 155; 2017, poz. 2491 oraz 2018, poz. 5 i 138) o skardze kasacyjnej. Wnioskodawca stwierdził mianowicie, że „upoważnienie Naczelnego Sądu Administracyjnego do stosowania w sprawach odwołań od uchwał KRS przepisów Kodeksu postępowania cywilnego o skardze kasacyjnej budzi wątpliwości konstytucyjne, jeśli chodzi o racjonalność ustawodawcy i zapewnienie spójności systemu prawnego, a zatem wątpliwości w kontekście realizacji zasad wynikających z demokratycznego państwa prawnego. Ponadto, przyznane kompetencje oddziałują na zasadę podziału i równowagi władzy w zakresie rozdziału kompetencji w ramach jednego segmentu władzy - tj. władzy sądowniczej. To powoduje ingerencje w konstytucyjnie wyznaczone kompetencje Naczelnego Sądu Administracyjnego. Wadliwe ukształtowanie procedury odwoławczej od uchwał Krajowej Rady Sądownictwa powoduje, że cała instytucja odwołań jest dysfunkcjonalna i jednocześnie nieproporcjonalnie ogranicza konstytucyjne kompetencje Prezydenta RP i KRS w procesie powoływania sędziów" (ibidem, s. 43-44).

Wnioskodawca podnosi, że odesłanie (i to w całości, a nie odpowiednio) do stosowania przepisów Kodeksu postępowania cywilnego w postępowaniu przed NSA w sprawach dotyczących uchwał KRS, które dotyczą jednego z etapów pro- 
cedury powoływania na stanowisko sędziego, ingeruje w istotę konstytucyjnych zadań powierzonych NSA wynikających z art. 184 Konstytucji. Kwestionowana regulacja, zdaniem wnioskodawcy, wprowadza stan niepewności prawnej, dając jednocześnie NSA możliwość korzystania z Kodeksu postępowania cywilnego „w bardzo szerokim zakresie, co nie jest konieczne dla realizacji przyznanej mu kompetencji. Taki stan rzeczy narusza zasady wynikające z art. 2 i art. 7 Konstytucji RP w kontekście związanym z zasadami tworzenia prawa oraz zasadą proporcjonalności. Ustawodawca przekroczył w danym przypadku granice swobody regulacyjnej" (ibidem, s. 44).

Kolejny argument przemawiający za sprzecznością z Konstytucją art. 44 ust. 3 uKRS dotyczy tego, że „wprowadzone rozwiązanie daje możliwość podejmowania rozstrzygnięć w oparciu o procedurę cywilną w sprawach ustrojowych, podczas gdy powoływanie sędziów nie jest sprawą w rozumieniu art. 1 Kodeksu postępowania cywilnego. Powoduje to naruszenie podstawowych zasad państwa prawnego polegających na odpowiednim przypisaniu kompetencji organom władzy publicznej, w tym kompetencji o charakterze nadzorczym i kontrolnym. [...] wskazany przepis powoduje, że postępowanie przed Krajową Radą Sądownictwa w zakresie dotyczącym uchwał zawierających wnioski przedstawiające Prezydentowi RP kandydatów na sędziów staje się swoistym postępowaniem administracyjnym, podlegającym weryfikacji NSA. W ten sposób dochodzi do ingerencji w konstytucyjne uprawnienie Prezydenta RP, który ma ograniczone prawo do skorzystania ze swojej prerogatywy wobec postępowania $\mathrm{w}$ sprawie uchwały KRS, toczącego się przed sądem" (ibidem, s. 44-45).

4.5. Uzasadniając zarzuty wyartykułowane w punkcie piątym petitum wniosku, wnioskodawca wskazuje na problemy konstytucyjne wynikające $\mathrm{z}$ art. 388 $\$ 1$ k.p.c. w związku $\mathrm{z}$ art. 44 ust. 3 uKRS w zakresie, w jakim umożliwia wstrzymanie uprawnień Prezydenta Rzeczypospolitej Polskiej do powołania sędziego. Zdaniem wnioskodawcy, „problem konstytucyjny wynikający ze skarżonej normy polega w pierwszym rzędzie na tym, że przy jej pomocy Naczelny Sąd Administracyjny może władczo oddziaływać na procedurę powoływania sędziów, co stoi w sprzeczności z konstytucyjnymi przepisami dotyczącymi tego zagadnienia. Ponadto regulacja ta stanowi naruszenie zasad państwa prawnego związanych z zasadami racjonalności ustawodawcy oraz spójności i określoności prawa. Wreszcie oddziałuje ona na pozycję ustrojową tak NSA, jak i Krajowej Rady Sądownictwa w kontekście koncepcji podziału i równowagi władzy. $Z$ tego względu zarysowana kompetencja budzi też wątpliwość co do jej zgodności z zasadą niezależności sądów, a w konsekwencji, jako że dotyczy powoływania sędziów, także z niezależnością sędziów" (ibidem, s. 46). Wnioskodawca sformułował szczegółowe argumenty uzasadniające zarzuty niezgodności zaskarżonej normy ze wskazanymi wzorcami kontroli.

4.6. Uzasadniając zarzuty wyartykułowane w punkcie szóstym petitum wniosku, wnioskodawca wskazuje na problemy konstytucyjne wynikające $\mathrm{z}$ art. 44 
ust. 4 uKRS. Zdaniem wnioskodawcy art. 44 ust. 4 uKRS „budzi wątpliwość co do zgodności z podstawowymi zasadami ustroju państwa, takimi jak zasada demokratycznego państwa prawnego, podziału i równowagi władzy, w tym zasada niezależności sądów i niezawisłości sędziów. Ponadto regulacja jest sprzeczna z konstytucyjnymi przepisami dotyczącymi powoływania sędziów, pozycją Krajowej Rady Sądownictwa oraz Naczelnego Sądu Administracyjnego. Przepis ten narusza też prawo dostępu obywateli do służby publicznej na jednakowych zasadach" (ibidem, s. 49). Wnioskodawca sformułował szczegółowe argumenty uzasadniające zarzuty niezgodności zaskarżonej normy ze wskazanymi wzorcami kontroli.

\section{Analiza formalnoprawna}

1. Wniosek, z którym wystąpiła Krajowa Rada Sądownictwa, ma podstawę prawną w art. 191 ust. 1 pkt 2 Konstytucji, zgodnie z którym: „Z wnioskiem w sprawach, o których mowa w art. 188, do Trybunału Konstytucyjnego wystąpić mogą: [... 2) Krajowa Rada Sądownictwa w zakresie, o którym mowa w art. 186 ust. 2".

Zgodnie z art. 186 ust. 2 Konstytucji: „Krajowa Rada Sądownictwa może wystąpić do Trybunału Konstytucyjnego z wnioskiem w sprawie zgodności z Konstytucją aktów normatywnych w zakresie, w jakim dotyczą one niezależności sądów i niezawisłości sędziów”.

W odniesieniu do legitymacji procesowej Krajowej Rady Sądownictwa w doktrynie wyrażony został pogląd, że „zgodnie z art. 186 ust. 2 Konstytucji RP KRS może wystąpić do TK z wnioskiem w sprawie zgodności z Konstytucją RP aktów normatywnych w zakresie, w jakim dotyczą one niezależności sądów i niezawisłości sędziów. Wydaje się, że zawarte w tym przepisie pojęcia niezależności sądów i niezawisłości sędziów powinny być poddane wykładni dynamicznej. Istotna dla przeprowadzenia tego typu rozumowania jest również ta część regulacji konstytucyjnej, która ustanawia dla KRS rolę »strażnika« tych wartości, a więc podmiotu zobowiązanego do ich optymalizacji (dążenia do osiągnięcia możliwe najpełniejszego celu), a nie tylko zwykłego ich wykonywania. Należy ponadto zauważyć, że z punktu widzenia ich instrumentalnego charakteru wobec realizacji prawa do sądu powinny być one umiejscawiane w kontekście nie tylko narzędzi umożliwiających przestrzeganie zasady separacji sądów oraz sposobu zapewnienia niezależności samych sędziów, ale przede wszystkim jako instrumenty gwarantujące możliwość zapewnienia uczestnikom obrotu prawnego właściwie ukształtowanego prawa do sądu. Określona w art. 186 ust. 2 Konstytucji RP legitymacja szczególna KRS zdaje się zatem odnosić do tych wszystkich przypadków, w których są rozpatrywane nie tylko kwestie samej niezależności sądów i niezawisłości sędziowskiej, lecz także takie instytucje prawa, które z punktu widzenia naruszenia tych dwóch instrumentów mogą budzić wątpliwości w sferze zapewnienia należycie ukształtowanego prawa do sądu” (K. Kozłowski, P. Tuleja, Ewolucja ustrojowej pozycji sądów a konstytucyjne zadania Krajowej Rady Sądownictwa, „Krajowa Rada Sądownictwa” 2015, nr 1, s. 20). 
Ze względu na fakt, że wnioskodawca kwestionuje przepisy ustawy o KRS, należy rozważyć problem dopuszczalności występowania Krajowej Rady Sądownictwa $\mathrm{z}$ wnioskiem o zbadanie konstytucyjności przepisów ustawy regulującej jej działalność.

W doktrynie pojawił się pogląd kwestionujący tę dopuszczalność (zob. P. Tuleja, Konstytucyjny status Krajowej Rady Sadownictwa [w:] Krajowa Rada Sadownictwa. XX-lecie działalności, red. P. Tuleja, Warszawa 2010, s. 82). Natomiast w innym miejscu powołany autor stwierdził, że: „Inaczej przebiega badanie dopuszczalności wniosków składanych przez podmioty mające ograniczoną legitymację procesową. Szczególną pozycję wśród tych podmiotów zajmuje Krajowa Rada Sądownictwa. W myśl art. 191 ust. 1 pkt 2 Konstytucji KRS może występować $\mathrm{z}$ wnioskiem w sprawie hierarchicznej kontroli norm w sprawach, o których mowa w art. 186 ust. 2 Konstytucji. Ustawa o TK nie przewiduje jednak wstępnej kontroli spełnienia tego wymogu. W praktyce wniosek KRS od razu kierowany jest do wyznaczonego składu orzekającego w celu jego rozpoznania. W razie wykroczenia wniosku poza zakres przedmiotowy art. 186 ust. 2 Konstytucji Trybunał powinien umorzyć postępowanie. Kontrola ta nie jest jednak rygorystyczna i można wskazać sprawy, w których dopuszczalność rozpoznania wniosku KRS budziła wątpliwości [Autor odsyła do zdania odrębnego W. Hermelińskiego do wyroku TK z 16 kwietnia 2008 r., sygn. akt K 40/07 - uwaga J.P.]. Rozwiązanie, w myśl którego ograniczona zostaje legitymacja podmiotu do składania wniosków przy równoczesnym braku wstępnej ich kontroli, jest niespójne. Skutkować może przekazywaniem do merytorycznego rozpoznania wniosków, które wykraczają poza zakres art. 186 ust. 2 Konstytucji” (P. Tuleja, Postępowanie przed Trybunałem Konstytucyjnym w sprawie hierarchicznej kontroli norm, „Przegląd Sejmowy" 2009, nr 5, s. 39).

Natomiast inni przedstawiciele doktryny wprost przyznają rację poglądowi o dopuszczalności występowania KRS z wnioskiem o zbadanie przepisów ustawy o KRS: „Wydaje się to o tyle uzasadnione, że niezgodne z Konstytucją zmiany w ustawie regulującej działalność Rady mogą uniemożliwić jej skuteczną realizację zadania określonego w art. 186 ust. 1 Konstytucji RP. Możliwość złożenia przez Radę wniosku do TK o zbadanie ustawy regulującej działalność KRS expressis verbis wskazał sam Trybunał [...]. Zdaniem TK, KRS może wystąpić do TK z wnioskiem o zbadanie zgodności z Konstytucją ustawy regulującej działalność TK w zakresie, w jakim niezależność TK i niezawisłość jego sędziów mają przełożenie na niezależność sądów i niezawisłość sędziów (wyr. TK z 9.12.2015 r., K 35/15, Legalis)" (K. Szczucki, Art. 186 [w:] Konstytucja RP, t. II, Komentarz. Art. 87-243, red. M. Safjan, L. Bosek, Warszawa 2016, nb. 22-23).

Kwestia dopuszczalności występowania Krajowej Rady Sądownictwa z wnioskiem o zbadanie przepisów ustawy o KRS została jednoznacznie pozytywnie rozstrzygnięta w orzecznictwie Trybunału Konstytucyjnego. Mianowicie rozpatrując sprawę o sygn. akt K 40/07 Trybunał Konstytucyjny stwierdził, że „sprawa 
rozpatrywana obecnie dotyczy objętych wnioskiem Krajowej Rady Sądownictwa kolejnych przepisów ustawy o KRS [...] Trybunał Konstytucyjny stwierdza, że stanie na straży niezależności sądów i niezawisłości sędziów i wynikająca stąd zdolność wnioskowa Rady przed Trybunałem obejmuje w efekcie nie tylko czuwanie nad formalnym przebiegiem postępowania nominacyjnego oraz procesu legislacyjnego w sprawach ustrojowo dotyczących tych dziedzin, ale również obronę pozycji ustrojowej samej Rady jako ustanowionej w Konstytucji instytucji o charakterze gwarancyjnym zabezpieczającej rzeczywistą ich niezależność i niezawisłość" (wyrok TK z 16 kwietnia 2008 r., sygn. akt K 40/07).

Powyższy pogląd został potwierdzony w wyroku o sygn. akt K 62/07, w którym Trybunał Konstytucyjny stwierdził, że „Krajowa Rada Sądownictwa (dalej: KRS) jest centralnym organem konstytucyjnym stojącym na straży niezależności sądów i niezawisłości sędziów. Zdolność wnioskowa KRS wynika z art. 186 ust. 2 Konstytucji. Należy przy tym zwrócić uwagę, że kwestia legitymacji KRS do skutecznego inicjowania postępowania przed Trybunałem Konstytucyjnym była już niejednokrotnie przedmiotem badania Trybunału. Ostateczne swoje stanowisko w tej kwestii Trybunał Konstytucyjny wyraził, orzekając w pełnym składzie 16 kwietnia 2008 r.: »Trybunał Konstytucyjny stwierdza, że stanie na straży niezależności sądów i niezawisłości sędziów i wynikająca stąd zdolność wnioskowa Rady przed Trybunałem obejmuje w efekcie nie tylko czuwanie nad formalnym przebiegiem postępowania nominacyjnego oraz procesu legislacyjnego w sprawach ustrojowo dotyczących tych dziedzin, ale również obronę pozycji ustrojowej samej Rady jako ustanowionej w Konstytucji instytucji o charakterze gwarancyjnym zabezpieczającej rzeczywistą ich niezależność i niezawisłość « (wyrok o sygn. K 40/07, OTK ZU nr 3/A/2008, poz. 44)" (wyrok TK z 19 listopada 2009 r., sygn. akt K 62/07).

W kontekście dotychczasowego orzecznictwa Trybunału Konstytucyjnego legitymacja Krajowej Rady Sądownictwa do występowania z wnioskiem o zbadanie zgodności z Konstytucją przepisów ustawy o KRS nie budzi wątpliwości.

2. Wniosek złożony został przez Krajową Radę Sądownictwa w dniu 22 listopada 2018 r., a więc pod rządami ustawy z dnia 30 listopada 2016 r. o organizacji i trybie postępowania przed Trybunałem Konstytucyjnym. Do wniosku mają zatem zastosowanie przepisy ustawy o TK, a w szczególności art. 46 i art. 47 tej ustawy. Zgodnie z art. 46 ustawy o TK: „Pismami procesowymi są wnioski, pytania prawne i skargi konstytucyjne, a także inne wnioski i oświadczenia uczestników postępowania, wnoszone do Trybunału w toku postępowania poza rozprawą”. Artykuł 47 ustawy o TK stanowi: „1. Wniosek złożony przez podmiot, o którym mowa w art. 191 ust. 1 pkt 1-5 Konstytucji, zawiera: 1) oznaczenie podmiotu uprawnionego do złożenia wniosku; 2) podanie podstawy prawnej działania podmiotu uprawnionego do złożenia wniosku; 3) oznaczenie rodzaju pisma procesowego; 4) określenie kwestionowanego aktu normatywnego lub jego części; 5) wskazanie wzorca kontroli; 6) uzasadnienie. 2. Uzasadnienie, 
o którym mowa w ust. 1 pkt 6, zawiera: 1) przywołanie treści kwestionowanego wnioskiem przepisu wraz z jego wykładnią; 2) przywołanie treści wzorców kontroli wraz z ich wykładnią; 3) określenie problemu konstytucyjnego i zarzutu niekonstytucyjności; 4) wskazanie argumentów lub dowodów na poparcie zarzutu niekonstytucyjności. [...]”.

3. Konieczność uzasadnienia zarzutu sformułowanego we wniosku związana jest $\mathrm{z}$ domniemaniem konstytucyjności norm prawnych oraz z zasadą skargowości. Zgodnie z wypowiedziami Trybunału Konstytucyjnego: „Kontrola konstytucyjności ustaw przebiega w oparciu o domniemanie, że badane normy są zgodne z konstytucją. Ciężar dowodu spoczywa na podmiocie kwestionującym zgodność ustawy z konstytucją i dopóki nie powoła on konkretnych i przekonywających argumentów prawnych na rzecz swojej tezy, dopóty Trybunał Konstytucyjny uznawać będzie kontrolowane przepisy za konstytucyjne. W przeciwnym razie naruszeniu uległaby zasada kontradyktoryjności postępowania przed Trybunałem Konstytucyjnym, a Trybunał przekształciłby się w organ orzekający z inicjatywy własnej" (zob. np. orzeczenia TK z: 26 kwietnia 1995 r., sygn. akt K 11/94; 31 stycznia 1996 r., sygn. akt K 9/95; wyrok TK z 27 czerwca 2008 r., sygn. akt $\mathrm{K}$ 51/07).

W orzecznictwie trybunalskim konsekwentnie podkreśla się, że prawidłowe pismo inicjujące postępowanie przed TK powinno zawierać szczegółową i precyzyjną jurydyczną argumentację uprawdopodobniającą stawiane zarzuty (zob. np. postanowienia TK z: 17 listopada 2011 r., sygn. akt Ts 40/11; 2 lutego 2012 r., sygn. akt Ts 93/11). Wymogu tego nie spełniają uwagi nazbyt ogólne, niejasne czy też czynione jedynie na marginesie innych rozważań (zob. np. wyrok TK z 5 czerwca 2014 r., sygn. akt K 35/11; postanowienie TK z 13 stycznia 2015 r., sygn. akt K 44/13). „Wobec respektowania generalnej zasady, jaką jest domniemanie konstytucyjności aktu normatywnego, samo wskazanie w petitum wzorca kontroli, bez szczegółowego odniesienia się w uzasadnieniu do kwestionowanej regulacji prawnej lub lakoniczne sformułowanie zarzutu niekonstytucyjności nie może zostać uznane za »uzasadnienie postawionego zarzutu, z powołaniem dowodów na jego poparcie« w rozumieniu przepisów regulujących postępowanie przed Trybunałem Konstytucyjnym. W świetle utrwalonej praktyki orzeczniczej wymóg ten należy rozumieć jako nakaz odpowiedniego udowodnienia zarzutów stawianych w kontekście każdego wskazanego wzorca kontroli” (postanowienie TK z 21 stycznia 2015 r., sygn. akt K 13/13). Jak stwierdził Trybunał Konstytucyjny w wyroku z 8 września 2005 r. (sygn. akt P 17/04): ,Zarzut niezgodności przepisu stanowiącego przedmiot zaskarżenia z Konstytucją, ratyfikowaną umową międzynarodową lub ustawą powinien być poparty przytoczeniem argumentów podważających domniemanie konstytucyjności przepisu" (zob. także postanowienie TK z 26 maja 2015 r., sygn. akt SK 6/13). W wyroku z 19 października 2010 r. (sygn. akt P 10/10) Trybunał wskazał, że: „[p]rzesłanka odpowiedniego uzasadnienia zarzutów nie powinna być traktowana powierzchownie i instru- 
mentalnie. Przytaczane w piśmie procesowym argumenty mogą być mniej lub bardziej przekonujące [...], lecz zawsze muszą być argumentami »nadającymi się« do rozpoznania przez Trybunał Konstytucyjny”. Oznacza to, że nie wystarczy sformułowanie samej tezy o niekonstytucyjności zaskarżonego przepisu. Uzasadnienie musi wskazywać precyzyjnie co najmniej jeden argument przemawiający za naruszeniem danego wzorca kontroli. Wymogu tego nie spełniają uwagi nazbyt ogólne, niejasne czy też czynione jedynie na marginesie innych rozważań (zob. np. wyrok TK z 5 czerwca 2014 r., sygn. akt K 35/11; postanowienie TK z 13 stycznia 2015 r., sygn. akt K 44/13). Jak wskazywał Trybunał: „Wobec respektowania generalnej zasady, jaką jest domniemanie konstytucyjności aktu normatywnego, samo wskazanie w petitum wzorca kontroli, bez szczegółowego odniesienia się w uzasadnieniu do kwestionowanej regulacji prawnej lub lakoniczne sformułowanie zarzutu niekonstytucyjności nie może zostać uznane za »uzasadnienie postawionego zarzutu, z powołaniem dowodów na jego poparcie« w rozumieniu przepisów regulujących postępowanie przed Trybunałem Konstytucyjnym. W świetle utrwalonej praktyki orzeczniczej wymóg ten należy rozumieć jako nakaz odpowiedniego udowodnienia zarzutów stawianych w kontekście każdego wskazanego wzorca kontroli” (postanowienie TK z 21 stycznia 2015 r., sygn. akt K 13/13).

4. Biorąc pod uwagę wymogi formalne dotyczące obowiązku sformułowania zarzutu niekonstytucyjności oraz wskazania argumentów lub dowodów na poparcie tego zarzutu, wniosek Krajowej Rady Sądownictwa w niektórych miejscach budzi zastrzeżenia.

4.1. W odniesieniu do żądania wnioskodawcy wyrażonego w punkcie pierwszym petitum wniosku zastrzeżenia budzi fakt, że wnioskodawca zaskarżył grupę przepisów dotyczących wyborów członków KRS, lecz zarówno problem konstytucyjny (którego istotę określił jako kwestię oceny, czy w kontekście powołanych wzorców konstytucyjnych dopuszczalne jest unormowanie przewidujące powoływanie sędziów-członków KRS przez inny podmiot niż samo środowisko sędziowskie), jak i sformułowane zarzuty wraz z uzasadnieniem dotyczą kwestii podmiotu dokonującego wyboru sędziów-członków KRS. W istocie zatem odnoszą się do przepisu art. 9a ust. 1 uKRS. Brak natomiast sformułowania zarzutów w odniesieniu do pozostałych zaskarżonych w tym punkcie przepisów oraz brak ich uzasadnienia. Przedmiotem merytorycznego rozpoznania będzie zatem zarzut niezgodności z powołanymi wzorcami art. 9a ust. 1 uKRS.

Wobec powyższego Sejm wnosi o umorzenie postępowania ze względu na niedopuszczalność wydania wyroku w zakresie zaskarżenia następujących przepisów: art. 9a ust. 2 i ust. 3, art. 11a, art. 11b, art. 11c, art. 11d i art. 11e uKRS).

4.2. W punkcie czwartym petitum wniosku wnioskodawca zarzucił, że art. 44 ust. 3 uKRS w zakresie, w jakim do postępowania przed Naczelnym Sądem Administracyjnym nakazuje stosowanie przepisów ustawy z dnia 17 listopada 1964 r. - Kodeks postępowania cywilnego (Dz. U. 2018, poz. 155; 2017, poz. 2491 
oraz 2018, poz. 5 i 138) o skardze kasacyjnej, jest niezgodny z art. 2, art. 7, art. 10, art. 144 ust. 3 pkt 17, art. 173, art. 178, art. 179 i art. 184 Konstytucji.

Wnioskodawca nie przedstawił adekwatnych zarzutów, które spełniałyby wymogi ustawowe. Przyjął założenie, że wątpliwa jest możliwość stosowania w postępowaniu przed NSA przepisów Kodeksu postępowania cywilnego o skardze kasacyjnej.

Wnioskodawca upatruje niekonstytucyjności w tym, że sąd administracyjny orzeka w przypadku odwołań od uchwał KRS z zastosowaniem procedury cywilnej, a nie administracyjnej. Wobec tego należy rozważyć, w jaki sposób kwestia rodzaju procedury stosowanej w postępowaniu sądowym jest adekwatna do zakresu legitymacji wnioskowej KRS, a więc czy jest to związane ze staniem na straży niezależności sądów i niezawisłości sędziów. W odniesieniu do tej kwestii należy stwierdzić, że KRS nie przysługuje legitymacja wnioskowa do kwestionowania rodzaju procedury stosowanej w postępowaniu sądowym.

Ponadto Konstytucja nie przesądza, że postępowanie przed sądem administracyjnym może toczyć się wyłącznie z zastosowaniem procedury administracyjnej, a nie procedury cywilnej. Z całą pewnością żaden z przepisów wskazanych przez wnioskodawcę w charakterze wzorców kontroli kwestii tej nie przesądza.

Wobec powyższego Sejm wnosi o umorzenie postępowania w odniesieniu do zarzutu, że art. 44 ust. 3 uKRS w zakresie, w jakim do postępowania przed Naczelnym Sądem Administracyjnym nakazuje stosowanie przepisów o skardze kasacyjnej, jest niezgodny z art. 2, art. 7, art. 10, art. 144 ust. 3 pkt 17, art. 173, art. 178, art. 179 i art. 184 Konstytucji.

\section{Wzorce kontroli}

\section{Artykuł 2 Konstytucji}

Artykuł 2 Konstytucji stanowi: „Rzeczpospolita Polska jest demokratycznym państwem prawnym, urzeczywistniającym zasady sprawiedliwości społecznej”.

1.1. Zgodnie z poglądem doktryny: „Wyrażona w art. 2 Konstytucji RP klauzula demokratycznego państwa prawnego stanowi podstawę do wyprowadzenia $\mathrm{z}$ niej katalogu zasad konstytucyjnych niesformułowanych wprost w przepisach. Zasady te dotyczą przede wszystkim stanowienia prawa. Istnieje stały katalog tych zasad wywodzony przede wszystkim z zasady zaufania osoby do państwa i stanowionego przez nie prawa. Katalog ten nie ma jednak charakteru zamkniętego i może zostać poszerzony, o ile doktryna, sądy oraz TK »odnajdą « w klauzuli państwa prawnego takie zasady, które są konieczne dla prawidłowego określenia relacji władzy publicznej i osoby. Klauzula państwa prawnego i zawarte w niej zasady wywierają istotny wpływ na wiele innych postanowień Konstytucji RP. Normatywna treść wielu przepisów ustrojowych oraz przepisów gwarantujących prawa człowieka jest ustalana przez odwołanie do klauzuli państwa prawnego. Klauzula ta stanowi również podstawę dokonywania wykładni ustaw w zgodzie 
z Konstytucją RP w procesie sądowego stosowania prawa. Warto podkreślić, że rola klauzuli państwa prawnego przy dokonywaniu wykładni ustaw w zgodzie z Konstytucją RP ma charakter szczególny. Niejednokrotnie przedmiotem takiej wykładni są bowiem przepisy ustaw stanowiące podstawę danej gałęzi prawa.

W związku z rolą, jaką odgrywa klauzula państwa prawnego dla ustrojowej charakterystyki państwa polskiego, jej wpływ na normatywną treść Konstytucji RP oraz oddziaływanie na płaszczyznę stanowienia i stosowania prawa można postawić pytanie: czy jest ona konstytucyjną klauzulą wiodącą, »zasadą-kluczem «, klauzulą, z której należy wyprowadzać cały porządek konstytucyjny? Wydaje się, że taką rolę klauzula państwa prawnego spełniała do 1997 r. Obecnie pełni ona nadal tę rolę w odniesieniu do formalnego aspektu państwa prawnego, w szczególności do płaszczyzny stanowienia prawa. W odniesieniu do aspektu materialnego należy stwierdzić, że obecnie ani doktryna, ani TK nie wywodzą nowych praw konstytucyjnych z art. 2 Konstytucji RP. Dla normatywnej treści wolności i praw człowieka kluczowe znaczenie ma natomiast obecnie art. 30 Konstytucji RP. To w zasadzie nienaruszalnej i niezbywalnej godności człowieka tkwi największy potencjał dla wydobywania z Konstytucji RP praw człowieka, dookreślania treści praw w ustawie zasadniczej wyrażonych oraz interpretowania konstytucyjnych klauzul limitacyjnych (L. Garlicki, Wolności i prawa jednostki, [Wolności i prawa jednostki w Konstytucji Rzeczypospolitej Polskiej z 1997 r. [w:] Pięć lat Konstytucji Rzeczypospolitej Polskiej. Materiały z konferencji na Zamku Królewskim w Warszawie, 17 października 2002, red. H. Jerzmański, Warszawa 2002 - uzupełnienie J.P.] s. 63 i n.)” (P. Tuleja, Art. 2 [w:] Konstytucja RP, t. I, Komentarz. Art. 1-86, red. M. Safjan, L. Bosek, Warszawa 2016, nb. 47).

Rozumienie zasady demokratycznego państwa prawa ukształtowane w orzecznictwie TK przed wejściem w życie Konstytucji RP z 1997 r. zostało podtrzymane pod rządami nowej Konstytucji, bowiem - jak twierdzi TK - „identyczności językowej towarzyszy [...] bliskość aksjologiczna - zespół wartości, który legł u podstaw nowelizacji grudniowej z 1989 r. znalazł potwierdzenie i rozwinięcie w Konstytucji z 2 kwietnia 1997 r. Tym samym, podstawowa treść zasady demokratycznego państwa prawnego wyrażona w art. 2 konstytucji, może i powinna być rozumiana w taki sam sposób, jak rozumiano treść tej zasady w poprzednim porządku konstytucyjnym” (wyrok z 25 listopada 1997 r., sygn. akt K 26/97). Jedyną różnicę stanowi - zdaniem TK - uwzględnienie faktu, że wiele zasad i reguł, które dotychczas funkcjonowały w polskim porządku konstytucyjnym tylko z racji ich „odnalezienia” w ogólnej klauzuli demokratycznego państwa prawa, pod rządami Konstytucji RP z 1997 r. znalazły bezpośredni wyraz w jej szczegółowych postanowieniach. TK uważa, że „obecnie pewne zasady i reguły znajdują wyraz zarówno w ogólnej klauzuli art. 2 konstytucji, jak też - niekiedy w sposób znacznie konkretniejszy - w dalszych szczegółowych postanowieniach tego aktu. Inne zasady i reguły, których nie powtórzono w dalszym tekście konstytucji, wynikają - tak, jak poprzednio - z ogólnej treści klauzuli demokratycznego pań- 
stwa prawnego i art. 2 konstytucji stał się ich jedyną i samoistną podstawą prawną" (wyrok TK z 25 listopada 1997 r., sygn. akt K. 26/97; zob. także wyroki TK z: 23 listopada 1998 r., sygn. akt SK 7/98; 13 kwietnia 1999 r., sygn. akt K 36/98; 12 kwietnia 2000 r., sygn. akt K 8/98; 8 marca 2004 r., sygn. akt SK 23/03).

Szeroko i w sposób syntetyczny na temat zasad wynikających z ogólnej zasady demokratycznego państwa prawa TK wypowiedział się w jednym z orzeczeń, stwierdzając, że „z zasady tej w orzecznictwie konstytucyjnym i w doktrynie wyprowadza się daleko idące konsekwencje, zarówno gdy chodzi o same wymagania co do techniki legislacyjnej (zasada przyzwoitej legislacji, określoności przepisów), jak i co do bezpieczeństwa prawnego (zasada ochrony zaufania do państwa i stanowionego przezeń prawa, zasada ochrony praw nabytych)" (wyrok z 20 listopada 2002 r., sygn. akt K 41/02; podobnie wyrok z 7 stycznia 2004 r., sygn. akt K 14/03; wyrok z 28 lipca 2004 r., sygn. akt P 2/04). W dalszej wypowiedzi TK sformułowana została bardzo istotna uwaga, że „teoretycznie wyróżnione i nazwane zasady na tle konkretnych stanów faktycznych splatają się ze sobą; niejasność przepisu w praktyce zwykle oznacza niepewność sytuacji prawnej adresata normy i pozostawienie jej ukształtowania organom stosującym prawo; z kolei zróżnicowanie indywidualnych rozstrzygnięć pociąga za sobą postrzeganie prawa jako niesprawiedliwego i utratę zaufania obywateli do państwa" (wyrok TK z 20 listopada 2002 r., sygn. akt K 41/02).

1.2. W kontekście zarzutu podniesionego przez wnioskodawcę, jak sam zaznacza, „należy przy ocenie konstytucyjności wziąć pod uwagę te treści art. 2 Konstytucji RP, które dotyczą wadliwej legislacji i nieproporcjonalnej ingerencji w konstytucyjnie ustalony mechanizm (zasady) powoływania sędziów, w którym ustawa zasadnicza przypisała określone role Prezydentowi RP i Krajowej Radzie Sądownictwa i nie przewidziała procedur kontroli tego postępowania, które nie ma charakteru administracyjnego, ale ustrojowy" (wniosek, s. 6).

1.3. Rozumienie zasady proporcjonalności wywodzonej z art. 2 Konstytucji Trybunał Konstytucyjny rozważał wielokrotnie. W szczególności szeroko na ten temat wypowiedział się w uzasadnieniu wyroku z 12 lutego 2014 r., sygn. akt K 23/10, mianowicie wyraził pogląd, że „wskazując na podstawy obowiązywania analizowanej zasady w Konstytucji oraz na rolę, jaką odgrywa ona w procesie kontroli konstytucyjności prawa, Trybunał stwierdził, że »konstytucjonalizacja zasady proporcjonalności oraz jej współczesne rozumienie wynika z materialnej koncepcji państwa prawnego, w tę bowiem koncepcję wpisane było założenie zagwarantowania określonego stopnia ochrony praw i wolności człowieka«. To sprawia, że na gruncie obecnej Konstytucji Trybunał wyróżnił trzy podstawy jej obowiązywania.

Po pierwsze, zasada proporcjonalności wynika z samej struktury norm konstytucyjnych określających sytuację jednostki względem władzy publicznej: "Zważywszy, że część norm konstytucyjnych ma charakter zasad, wyrażających zakazy bądź nakazy optymalizacyjne, oraz że kolizje między tymi zasadami mogą 
być rozstrzygane wyłącznie na podstawie zasady proporcjonalności, należy przyjąć, że zasada ta ma charakter obowiązujący. Wyznaczona przez zasady konstytucyjne sytuacja prawna jednostki nie może być w sposób definitywny ustalana in abstracto bez odwołania się do zasady proporcjonalności«. Trybunał podkreślił jednak, że ustrojodawca w art. 31 ust. 3 Konstytucji wyraźnie zastrzegł, że taką rolę na gruncie Konstytucji zasada proporcjonalności odgrywa wyłącznie przy limitowaniu wolności i praw jednostki. Art. 31 ust. 3 Konstytucji koncentruje się na wskazaniu przesłanek wprowadzania ograniczeń konstytucyjnych wolności i praw, zaś zawarta w nim zasada proporcjonalności wyznacza maksymalne granice owych ograniczeń.

Po drugie, w wypadku prawa do ochrony danych osobowych i wolności uzewnętrzniania religii, zasada proporcjonalności jest wyprowadzana także z dwóch szczegółowych przepisów rozdziału II, tj. art. 51 ust. 2 i art. 53 ust. 5 Konstytucji.

Po trzecie wreszcie, pod rządami Konstytucji z 1997 r., jedną z podstaw obowiązywania zasady proporcjonalności wciąż pozostaje art. 2 i wyrażona w nim zasada demokratycznego państwa prawnego. Stanowisko to nie było jednak w orzecznictwie Trybunału od początku oczywiste. [...] Z czasem w orzecznictwie Trybunału zaczął jednak przeważać pogląd, że w sytuacji gdy nie jest możliwe przeprowadzenie testu proporcjonalności w oparciu o art. 31 ust. 3 Konstytucji, dopuszczalne jest przywołanie jako bezpośredniej podstawy zasady proporcjonalności art. 2 Konstytucji. Brak możliwości przeprowadzenia testu proporcjonalności na podstawie art. 31 ust. 3 Konstytucji Trybunał dostrzegał na przykład wtedy, gdy zakwestionowana regulacja ingerowała w prawa lub wolności jednostki (osoby fizycznej lub osoby prawa prywatnego) zagwarantowane jedynie na poziomie ustawowym, a nie konstytucyjnym, albo gdy ograniczenie dotyczyło praw podmiotów publicznych (np. jednostek samorządu terytorialnego). W wyroku z 25 listopada 2003 r., sygn. K 37/02 (OTK ZU nr 9/A/2003, poz. 96), Trybunał stwierdził, że »[z]akres ingerencji dopuszczalnej dla ochrony ogólnego interesu publicznego wyznaczać powinien [...] każdorazowo postulat proporcjonalności, który nie znajdując wprost oparcia w art. 31 ust. 3 Konstytucji (odnoszącym się ze względu na usytuowanie tego przepisu w rozdziale II do osób fizycznych i innych podmiotów prywatnoprawnych) może być poszukiwany w art. 2 Konstytucji, ponieważ stanowi istotny komponent zasad, które składają się na pojęcie demokratycznego państwa prawa«.

Znaczący dla ugruntowania tego poglądu był wyrok Trybunału z 13 marca 2007 r., sygn. K 8/07 (OTK ZU nr 3/A/2007, poz. 26), w którym Trybunał wskazał, że zarzut nieproporcjonalności uregulowania może być oparty wyłącznie na naruszeniu art. 2 Konstytucji jako "zarzut nierzetelnego, niezrozumiale intensywnego działania ustawodawcy, korzystającego ze swej swobody regulacyjnej«, jednak wtedy będzie oceniany bez nawiązania do wkroczenia w podmiotowe prawa konstytucyjne. Stanowisko to zostało podtrzymane i rozwinięte w wyroku z 16 lipca 2009 r., sygn. Kp 4/08 (OTK ZU nr 7/A/2009, poz. 112), 
wydanym w pełnym składzie, w którym Trybunał stwierdził, że »[w]ywiedziona $\mathrm{z}$ art. 2 Konstytucji zasada proporcjonalności szczególny nacisk kładzie na adekwatność celu legislacyjnego i środka użytego do jego osiągnięcia. To znaczy, że spośród możliwych (i zarazem legalnych) środków oddziaływania należałoby wybrać środki skuteczne dla osiągnięcia celów założonych, a zarazem najmniej uciążliwe dla podmiotów, wobec których mają być zastosowane, lub dolegliwe w stopniu nie większym niż jest to niezbędne dla osiągnięcia założonego celu. Rozpatrując zgodność zakwestionowanej regulacji z zasadą proporcjonalności (z art. 2 Konstytucji) należy zbadać trzy istotne zagadnienia: 1) czy ta regulacja jest niezbędna dla ochrony i realizacji interesu publicznego, z którym jest związana, 2) czy jest efektywna, umożliwiając osiągnięcie zamierzonych celów, 3) czy jej efekty pozostają w odpowiedniej proporcji do ciężarów nakładanych na obywatela lub inny podmiot prawny«. Stanowisko to zostało potwierdzone w kolejnych orzeczeniach Trybunału (zob. np. wyroki z: 9 lipca 2012 r., sygn. P 8/10, OTK ZU nr 7/A/2012, poz. 75; 18 lipca 2013 r., sygn. SK 18/09, OTK ZU nr 6/A/2013, poz. 80).

Istotny dla ustalania treści zasady proporcjonalności wywodzonej z art. 2 Konstytucji był także wyrok TK z 9 lipca 2012 r., sygn. P 8/10, w którym Trybunał:

- uznał art. 2 Konstytucji, po pierwsze, za źródło zasady proporcjonalności, a po drugie, za wzorzec, który może być wskazany jako wyłączna podstawa kontroli konstytucyjności (zasada adekwatności rozwiązań ustawodawczych do zakładanego celu regulacji jest bowiem jednym z elementów zasady demokratycznego państwa prawnego; ze względu jednak na swoją treść stanowi odrębną zasadę $\mathrm{w}$ stosunku do zasad tradycyjnie wywodzonych $\mathrm{z}$ art. 2 Konstytucji: zasady zaufania obywatela do państwa i stanowionego przez nie prawa, zasady poprawnej legislacji, zakazu retroakcji czy zasady sprawiedliwości społecznej);

- wskazał, że wyprowadzana z art. 2 Konstytucji zasada adekwatności (proporcjonalności) rozwiązań ustawodawczych do zakładanego celu dotyczy formalnego sposobu korzystania przez ustawodawcę ze swobody regulacyjnej, $\mathrm{w}$ oderwaniu od oceny wkraczania $\mathrm{w}$ konkretne podmiotowe prawa konstytucyjne;

- uznał, że ocena naruszenia zasady adekwatności (proporcjonalności) rozwiązań ustawodawczych do zakładanego celu powinna być badana z perspektywy efektywności regulacji, konieczności oraz stopnia jej dolegliwości;

- stwierdził, że charakter zarzutu niezgodności z Konstytucją (brak proporcjonalności ze względu na cel ustawy) "przemawia za daleko idącą wstrzemięźliwością Trybunału Konstytucyjnego w ocenie celowości i efektywności posunięć ustawodawcy «, co wiąże się z tym, że Trybunał nie jest powołany do kontrolowania celowości i trafności rozwiązań przyjmowanych przez ustawodawcę, punktem wyjścia przy ocenie zgodności kwestionowanych przepisów z Konstytucją jest założenie racjonalności ustawodawcy i domniemanie zgodności ustawy z Konstytucją. Trybunał bowiem »interweniuje dopiero w tych przypadkach, gdy 
ustawodawca przekracza zakres przyznanej mu swobody regulacyjnej w sposób na tyle drastyczny, że ewidentne stało się naruszenie konstytucyjnych generalnych zasad .

- w konsekwencji przyjął za konieczne przedstawienie »w postępowaniu przed Trybunałem takich argumentów przemawiających za obaleniem konstytucyjności rozwiązania przyjętego przez ustawodawcę, by móc stwierdzić przede wszystkim brak osiągnięcia zakładanych przez ustawodawcę celów « oraz wykazanie drastycznego naruszenia tych celów przez kwestionowane przepisy lub występowania rażących skutków ubocznych wprowadzonej regulacji w związku z wartością celu, do którego ta regulacja zmierza" (wyrok TK z 12 lutego 2014 r., sygn. akt K 23/10).

\section{Artykuł 7 Konstytucji}

Artykuł 7 Konstytucji stanowi: „Organy władzy publicznej działają na podstawie i w granicach prawa”.

2.1. W doktrynie podkreśla się, że unormowanie zawarte w art. 7 Konstytucji „to jedno z najbardziej nieprecyzyjnych postanowień Konstytucji. W art. 7 sformułowano zasadę powstałą w czasach, w których konstytucji przypisywano rolę niewiążącej ogólnej deklaracji politycznej. W tym okresie francuska nauka prawa publicznego wypracowała zasadę legalności. Oznaczała ona oparcie działalności państwa na ustawie. Jeśli w warunkach dziewiętnastowiecznej Francji (i też przez większość XX w.) miała ona sens, to $\mathrm{z}$ chwilą przypisania konstytucji najwyższej mocy normatywnej zwierzchnictwo ustawy zostało poważnie nadwerężone. [...] Postanowienia omawianego artykułu nakazują organom władzy publicznej działać na podstawie i w granicach prawa. Powstaje pytanie, o jakie prawo tutaj chodzi. [...] coraz częstsze odchodzenie w praktyce sądowej od ścisłej wykładni literalnej, której wymaga art. 7 Konstytucji - na pewno w odniesieniu do norm kompetencyjnych - każe się zastanowić nad jego dalszą przydatnością. Trybunał Konstytucyjny pozwolił sobie na uwagę, że wzbogacenie podstaw kontroli, między innymi o zasadę legalizmu, gdy w grę wchodzi konstytucyjna regulacja bardziej szczegółowa, "nie zawsze jest racjonalne« (z uzasadnienia wyroku TK z 25 maja 1998 r., U 19/97, Lexis.pl nr 348450) Do tej uwagi można dodać niemal całkowite pozostawienie na uboczu przez Trybunał Konstytucyjny drugiej części formuły »w granicach prawa« - będącej wyrazem tzw. praworządności materialnej" (K. Complak, Art. 7. Działanie na podstawie i $w$ granicach prawa [w:] Konstytucja Rzeczypospolitej Polskiej. Komentarz, red. M. Haczkowska, Warszawa 2014, s. 20).

W odniesieniu do genezy art. 7 Konstytucji doktryna stwierdza także, iż „sformułowanie nakazu działania na podstawie i w granicach prawa stanowiło cezurę przekształcenia monarchii absolutnej w monarchię konstytucyjną. Uznanie, że prawem jest przede wszystkim ustawa, było z kolei podstawą nadania monarchii konstytucyjnej charakteru państwa demokratycznego. Wreszcie przyjęcie, że 
działanie na podstawie prawa oznacza również wymóg działania na podstawie Konstytucji, stało się podstawą funkcjonowania współczesnego demokratycznego państwa prawnego" (P. Tuleja, Art. 7 [w:] Konstytucja RP, t. I, Komentarz. Art. 1-86, red. M. Safjan, L. Bosek, Warszawa 2016, nb. 1).

2.2. W odniesieniu do wynikającej $\mathrm{z}$ art. 7 Konstytucji zasady legalizmu Trybunał Konstytucyjny wyraził pogląd, że „zasada praworządności (legalizmu) została przewidziana $\mathrm{w}$ art. 7 Konstytucji, zgodnie $\mathrm{z}$ którym »organy władzy publicznej działają na podstawie i w granicach prawa«. Legalizm działalności organów administracji publicznej polega m.in. na wydawaniu przez nie rozstrzygnięć w przepisanej prawem formie, na należytej podstawie prawnej i w zgodności $\mathrm{z}$ wiążącymi dany organ przepisami materialnymi. Zasada ta dotyczy nie tylko organów publicznych tworzących prawo, ale też stosujących je organów. Naruszenie przez organy państwa obowiązku działania na podstawie i w granicach prawa sprawia, że działanie takie traci cechę legalności. W dotychczasowym orzecznictwie Trybunał podkreślał, że istotą art. 7 Konstytucji jest nakaz działania organów władzy publicznej w granicach wyznaczonych przez prawo, w którym winna być zawarta podstawa działania, jak też zakreślone granice jej działania (zob. postanowienie z 9 maja 2005 r., sygn. Ts 216/04, OTK ZU nr 2/B/2006, poz. 87).

Zasada wyrażona $w$ art. 7 Konstytucji nie ma charakteru wyłącznie formalnego, który by powodował, że konstytucyjne uwarunkowania dotyczące treści przepisów prawnych nie wynikają z art. 7, ale z klauzuli wyrażonej w art. 2 Konstytucji i pozostałych zasad ustrojowych. Takie uwarunkowania wynikają bowiem również z samego art. 7 Konstytucji (zob. W. Sokolewicz, komentarz do art. 7 Konstytucji, [w:] Konstytucja Rzeczypospolitej Polskiej. Komentarz, red. L. Garlicki, Warszawa 2007, s. 3). Trybunał podkreśla, że art. 7 Konstytucji nakłada przede wszystkim na organy państwowe obowiązek działania zgodnie z obowiązującymi przepisami kompetencyjnymi, a nie wypływają z niego dodatkowe uprawnienia względem tych, które wynikają $\mathrm{z}$ innych norm prawnych. Art. 7 Konstytucji ma jednak też samoistne znaczenie, bo jest dyrektywą »interpretacji przepisów kompetencyjnych w sposób ścisły i z odrzuceniem w odniesieniu do organów władzy publicznej zasady: co nie jest zakazane, jest dozwolone« (wyrok TK z 27 maja 2002 r., sygn. K 20/01, OTK ZU nr 3/A/2002, poz. 34)" (wyrok z 12 maja 2015 r., sygn. akt $P$ 46/13).

2.3. „W najbardziej ogólnym ujęciu nakaz działania organów władzy publicznej na podstawie i w granicach prawa ma szeroki zakres przedmiotowy. Wyraża on zarówno zasadę legalizmu w wąskim znaczeniu, nakaz działania na podstawie prawa, jak i obowiązek przestrzegania prawa (zob. W. Sokolewicz, Artykut 7, w: Garlicki, Konstytucja, t. 5, s. 3 [Konstytucja Rzeczypospolitej Polskiej. Komentarz, t. V, red. L. Garlicki, Warszawa 2007 - uzupełnienie J.P.]" (P. Tuleja, Art. 7 [w:] Konstytucja RP, op. cit., nb. 7).

„Z Konstytucji RP wynika, że podstawowym aktem normatywnym na podstawie, którego działają organy władzy publicznej, jest ustawa. Potwierdza to kształt 
zasady wyłączności ustawy. Zasada ta ma z jednej strony legitymizować działanie organów władzy publicznej, z drugiej określać granicę ingerencji w prawa człowieka przez te organy. Stąd wynika zakaz domniemania kompetencji przez organy władzy publicznej. Prawem w rozumieniu art. 7 Konstytucji RP są również wszystkie akty powszechnie obowiązujące, o których mówi Rozdział III Konstytucji RP - Źródła prawa: »Zgodnie z art. 7 Konstytucji, organy władzy publicznej działają na podstawie i w granicach prawa. Oznacza to powinność organu władzy publicznej przestrzegania wszystkich przepisów, niezależnie od usytuowania ich w systemie źródeł prawa, które określają jego uprawnienia lub obowiązki. Organy muszą zatem znać przepisy regulujące ich kompetencje i stosować się do wynikających z nich nakazów i zakazów. Z konstytucyjnej zasady legalizmu wynika zatem, że nie mogą podejmować działań bez podstawy prawnej czy unikać wykonania kompetencji, jeżeli wiążące normy prawne nakładają na te organy określone obowiązki (por. wyrok TK z 21 lutego 2001 r., sygn. P 12/00, OTK ZU nr 3/2001, poz. 47, pkt III.6 i cytowana tam literatura) (post. TK z 4.10.2011 r., P 9/11, OTK-A 2011, Nr 8, poz. 86)” (P. Tuleja, Art. 7 [w:] Konstytucja RP, op. cit., nb. 11,).

Zgodnie z poglądem wyrażonym w doktrynie, „nakaz działania na podstawie i w granicach prawa ma charakter reguły nieprzewidującej żadnych wyjątków. Statuuje on też domniemanie takiego działania. Domniemywa się, że organy władzy publicznej działają na podstawie i w granicach prawa. Domniemanie to jest jednak obalalne. W formach prawem przewidzianych może dojść do stwierdzenia, że organ władzy publicznej naruszył art. 7 Konstytucji RP. Należy jednak podkreślić, że przesłanki obalenia tego domniemania oraz jego skutki kształtowane są nie tylko przez art. 7 , ale również przez inne zasady konstytucyjne. Przede wszystkim przez zasadę zaufania obywateli do państwa. Powyższa konstatacja dotyczy działalności ustawodawcy, sądów, organów władzy wykonawczej i wszystkich pozostałych organów władzy publicznej. W odniesieniu do ustawodawcy TK stwierdził m.in.: »W myśl art. 2 Konstytucji Rzeczpospolita Polska jest państwem prawnym, a w świetle art. 7 Konstytucji, organy władzy publicznej działają na podstawie i w granicach prawa. Jedną z fundamentalnych wartości prawa w ogóle i państwa prawnego w szczególności jest bezpieczeństwo prawne i pewność prawa. [...] W pewnych sytuacjach nawet rażące naruszenie prawa nie musi prowadzić do uchylenia aktu naruszającego. Zależne jest to od wyważenia racji leżących u podstaw nakazu przestrzegania prawa oraz zasady pewności prawa«. Konstytucyjną niedopuszczalność stwierdzenia nieważności decyzji rażąco naruszającej prawo w pewnych okolicznościach wskazał TK przy okazji kontroli konstytucyjności art. $156 \$ 2$ KPA [Kodeksu postępowania administracyjnego - uzupełnienie J.P.]: »Zasada praworządności jest zasadą instrumentalną względem zasady pewności prawa i zaufania obywatela do państwa, $\mathrm{w}$ tym sensie, że działanie na podstawie i w granicach prawa jest warunkiem koniecznym realizacji zasad pewności i zaufania«. Co do zasady działanie na 
podstawie i w granicach prawa jest instytucjonalnie realizowane w ten sposób, że ustawa określa kompetencje, prawne formy działania i materialne podstawy rozstrzygnięcia organu władzy publicznej. Wydanie decyzji zgodnej z prawem gwarantowane jest przez odpowiednie procedury, w tym prawo do zaskarżania orzeczeń i ich sądową kontrolę. Konsekwencją powyższych rozwiązań jest trwałość decyzji, co do której domniemywa się, że jest zgodna z prawem. Trwałość (prawomocność) jest więc elementem wzmacniającym zasadę praworządności. Powyższa relacja jest bardziej złożona w sytuacji, gdy organ władzy publicznej, mimo wskazanych wyżej gwarancji instytucjonalnych i proceduralnych, narusza prawo (zasadę praworządności), jednak jego decyzja wchodzi do obrotu, korzysta $\mathrm{z}$ cechy trwałości i kształtuje sytuację prawną (w szczególności przez długi okres). Wtedy występuje kolizja zasad, ponieważ reguła trwałości decyzji realizuje zasadę pewności prawa (bezpieczeństwa prawnego) i w ograniczonym zakresie zasadę zaufania (mając na względzie ukształtowane prawa adresatów decyzji), a instytucje służące wzruszaniu trwałości decyzji ze względu na naruszenie prawa służą zasadzie praworządności (wyr. z 12.5.2015 r., P 46/13, OTK-A 2015, Nr 5, poz. 62)” (P. Tuleja, Art. 7 [w:] Konstytucja RP, op. cit., nb. 15).

Rozważając relacje pomiędzy zasadą demokratycznego państwa prawa a zasadą legalizmu w doktrynie, podkreśla się, że „wyrażona w art. 7 Konstytucji RP zasada jest elementem składowym zasady państwa prawnego. Związek zasady praworządności z zasadą państwa prawnego ma charakter wielopłaszczyznowy: po pierwsze - zasada państwa prawnego stanowi uzasadnienie obowiązywania zasady praworządności, w szczególności wskazuje wartości stanowiące ratio art. 7, po drugie - stanowi podstawę określenia skutków naruszenia art. 7 przez organy władzy publicznej. Zasada praworządności wiąże się z zasadą nadrzędności Konstytucji RP (art. 8) oraz zasadą przychylności prawa polskiego prawu międzynarodowemu (art. 9)" (ibidem, nb. 17).

2.4. Określając relacje zasad konstytucyjnych związanych z zasadą demokratycznego państwa prawa, TK stwierdził m.in., że „zasada demokratycznego państwa prawnego, wyrażona w art. 2 Konstytucji, ma pierwszoplanowe znaczenie i szeroki zakres, a zasada praworządności, przewidziana w art. 7, z niej wynika i stanowi jej konsekwencję (zob. W. Sokolewicz, komentarz do art. 7 Konstytucji, w: Konstytucja..., s. 3-4). Zasada praworządności »stanowi jądro zasady państwa prawnego «, choć formalnie na tle Konstytucji jest zasadą równoległą do klauzuli państwa prawnego (tenże, komentarz do art. 2 Konstytucji, tamże, s. 16). W trakcie prac nad projektem Konstytucji pojawiały się nawet głosy, że art. 7 jest superfluum względem art. 2. Ostatecznie jednak zwyciężyło stanowisko, mówiące, że artykuł ten jest potrzebny, bowiem powiela treść poprzedniej Konstytucji, na tle której zrodziło się bogate orzecznictwo, a ponadto spełnia on funkcję edukacyjną.

Jednocześnie $\mathrm{z}$ art. 2 Konstytucji wywodzone są w orzecznictwie Trybunału zasady pochodne, w tym jest on źródłem zasady zaufania obywatela do państwa 
i zasady bezpieczeństwa prawnego (pewności prawa). Zasady konstytucyjne, istotne dla rozpoznania niniejszej sprawy, mają więc wspólne źródło w szeroko rozumianej klauzuli demokratycznego państwa prawnego. [...] Żadna z powyższych zasad nie ma charakteru bezwzględnego, bowiem od obu dopuszczalne są wyjątki” (wyrok z 12 maja 2015 r., sygn. akt P 46/13).

\section{- 3. Artykuł 10 Konstytucji}

Artykuł 10 Konstytucji stanowi: „1. Ustrój Rzeczypospolitej Polskiej opiera się na podziale i równowadze władzy ustawodawczej, władzy wykonawczej i władzy sądowniczej. 2. Władzę ustawodawczą sprawują Sejm i Senat, władzę wykonawczą Prezydent Rzeczypospolitej Polskiej i Rada Ministrów, a władzę sądowniczą sądy i trybunały".

3.1. Idea podziału władz leży u podstaw współczesnego konstytucjonalizmu demokratycznego. Nawiązuje do niej Konstytucja w art. 10. „Działalność państwa zostaje $\mathrm{w}$ art. 10 ust. 1 podzielona na trzy rodzajowo różne sfery działania, funkcje. Sprzyja to zachowaniu jedności władzy państwowej w rękach suwerena (narodu, ludu), ale równocześnie emanacja tej władzy zostaje rozdzielona między funkcje i wypełniające te funkcje organy. Poszczególne władze nie mają w tym ujęciu charakteru samodzielnego, ale wypełniają swoje funkcje na podstawie kompetencji przyznanych im przez Konstytucję uchwaloną przez suwerena stojącego nad nimi. Do funkcji tych należą: 1) prawodawstwo polegające na wydawaniu ogólnie obowiązujących norm prawnych; 2) wykonawstwo stanowiące realizację zadań państwa w odniesieniu do konkretnych przypadków, Z wyjątkiem sytuacji spornych; 3) sądownictwo polegające na rozstrzyganiu sporów prawnych" (B. Banaszak, Konstytucja Rzeczypospolitej Polskiej. Komentarz, Warszawa 2009, s. 82).

W doktrynie podkreśla się, że „Trybunał Konstytucyjny interpretował zasadę podziału i równoważenia władzy w odniesieniu do wszystkich władz wymienionych w art. 10 ust. 2 Konstytucji RP. Największa liczba orzeczeń dotyczy władzy sądowniczej oraz jej relacji z organami władzy ustawodawczej i wykonawczej. W odniesieniu do władzy ustawodawczej art. 10 był stosowany dla wyznaczenia dopuszczalnego zakresu ustawodawstwa. Zdaniem TK ograniczenia takie są immanentną cechą zasady podziału władzy: »Poza dyskusją pozostaje okoliczność, że w demokratycznym państwie prawnym, którego ustrój oparty jest na podziale władz, stanowienie prawa należy do władzy ustawodawczej. Granice swobody ustawodawczej określają normy konstytucyjne. W orzecznictwie Trybunału Konstytucyjnego wyrażany był pogląd, że ustawodawca jest uprawniony do stanowienia prawa odpowiadającego założonym celom politycznym i gospodarczym« (wyr. z 20.2.2002 r., K 39/00, OTK-A 2002, Nr 1, poz. 4). Demokratycznie legitymowany ustawodawca stanowi prawo w oparciu o zasadę swobodnej kompetencji prawodawczej oraz zasadę wyłączności ustawy. Konstytucyjne granice władzy ustawodawczej mają aspekt negatywny i pozytywny. Pierwszy 
oznacza zakaz stanowienia norm niezgodnych z Konstytucją RP, drugi - nakaz stanowienia norm konkretyzujących postanowienia Konstytucji RP. Aspekt pozytywny oznacza również regulowani[e] materii ustawowej przez Sejm i Senat: »W porządku prawnym proklamującym zasadę podziału władz, opartym na prymacie ustawy jako podstawowego źródła prawa wewnętrznego, parlament nie może w dowolnym zakresie cedować funkcji prawodawczych na organy władzy wykonawczej. Zasadnicza regulacja nie może być domeną przepisów wykonawczych, wydawanych przez organy nienależące do władzy ustawodawczej. Nie jest bowiem dopuszczalne, aby prawodawczym decyzjom organu władzy wykonawczej pozostawić kształtowanie zasadniczych elementów regulacji prawnej (zob. wyr. z 26.3.2013 r., K 11/12, OTK-A 2013, Nr 3, poz. 28 i cyt. tam orzeczenia)" (M. Pach, P. Tuleja, Art. 10 [w:] Konstytucja RP, t. I, Komentarz. Art. 1-86, red. M. Safjan, L. Bosek, Warszawa 2016, nb. 49).

3.2. Istotną kwestię w odniesieniu do art. 10 Konstytucji podniósł P. Sarnecki, który postawił pytanie, czy artykuł ten jest normą kompetencyjną, „co oznaczałoby że, zgodnie z zasadą legalizmu (art. 7 konstytucji), stanowiłby on podstawę prawną do podejmowania działań (także władczych), zwłaszcza przez wymienione w nim expressis verbis organy, a chodziłoby tu o działania, które swym charakterem stanowiłyby wyraz wykonywania jednej z trzech, wymienionych w tym przepisie, »władz« (w znaczeniu funkcjonalnym), a które nie byłyby ujęte $\mathrm{w}$ jakimkolwiek innym, konkretnym przepisie prawnym.

W dotychczasowym rozumieniu zasady podziału władzy w doktrynie wskazywano, że na płaszczyźnie określania kompetencji rozmaitych organów, ogólne sformułowanie zasady trójpodziału władzy oznacza jedynie stworzenie trojakiego rodzaju domniemania kompetencyjnego, przypisującego parlamentowi - możliwość tworzenia norm prawnych o podstawowym znaczeniu tudzież sprawowania ogólnej kontroli politycznej, głowie państwa (lub głowie państwa i rządowi) - sprawowanie przede wszystkim rządzenia państwem i zarządzania procesem realizacji ustaw, sądom - sprawowanie wymiaru sprawiedliwości. To domniemanie, zgodnie ze swą naturą, ustępowałoby tylko wobec jednoznacznych, szczegółowych przepisów konstytucyjnych i ustawowych, wskazujących na inne organy: czy to na organy innej władzy, czy też nawet na organy spoza zasadniczej triady władz, jako właściwych do podejmowania pewnych działań ustawodawczych, wykonawczych czy sądowniczych. Jak pisał W. Komarnicki »dla przeprowadzenia zasady podziału władz w znaczeniu właściwym, tj. względnym, wystarczy taki podział funkcji państwowych, przy którym zasadniczo do właściwej władzy należą funkcje materialnie jej przynależne, wyjątkowo zaś mogą być one sprawowane przez inną władzę, czyli że zasada ta polega na istnieniu domniemania kompetencyjnego na rzecz odpowiedniej władzy, które jedynie przez wyraźny przepis może być uchylone« (Polskie prawo polityczne, Warszawa 1922, s. 219 i powołana tam literatura oraz W. Maliniak, Zagadnienie podziału władz w prawie państwowym nowoczesnym, Warszawa 1937; przedrukowane w zbiorze 
Przeciw fetyszyzmowi konstytucyjnemu, Kraków 2012, s. 425: »istota podziału władz polega na istnieniu domniemania kompetencyjnego na rzecz organu normalnego $\ll)$.

W odpowiedzi na postawione tu pytanie należy odwołać się przede wszystkim do obfitego orzecznictwa TK, dotyczącego kwestii podstaw kompetencyjnych do działania władz publicznych. W syntetyczny sposób odniósł się on do tego zagadnienia w uchwale wykładniczej z 10 maja 1994 r., W 7/94, stwierdzając: »zdaniem TK z konstytucyjnej zasady legalności, jak również zasady demokratycznego państwa prawa wynika jednoznaczny wniosek, że w przypadku, gdy normy prawne nie przewidują wyraźnie kompetencji organu państwowego, kompetencji tej nie wolno domniemywać i w oparciu o inną rodzajowo kompetencję przypisywać ustawodawcy zamiar, którego nie wyraził «. W ramach obecnej konstytucji teza ta wydaje się jeszcze w wyższym stopniu uzasadniona, gdyż zasada legalności (art. 7) jest ujęta w niej bardziej kompleksowo niż w art. 3 ust. 2 przepisów konstytucji z 1952 r. (»Wszystkie organy władzy i administracji państwowej działają na podstawie przepisów prawa«), utrzymanego w mocy przez m.k. z 17 października 1992 r. Jak stwierdza J. Oniszczuk, »Trybunał w swoim orzecznictwie zajmował w sprawie przepisów kompetencyjnych stanowisko zdecydowane, stwierdzając wielokrotnie, iż przepis kompetencyjny podlega zawsze wykładni literalnej, domniemanie objęcia upoważnieniem materii w nim niewymienionych w drodze na przykład wykładni celowościowej nie może wchodzić w rachubę« [...] [J. Oniszczuk, Konstytucja Rzeczypospolitej Polskiej w orzecznictwie Trybunału Konstytucyjnego, Kraków 2000, s. 914 - uzupełnienie J.P.].

Należy w tym względzie, jak się wydaje, przyjąć stanowisko, że wymaganą w art. 7 konstytucji podstawą prawną może być również komentowany artykuł, ale jedynie w zakresie obejmującym »istotę« danej władzy. Każde domniemanie kompetencyjne, a więc i to $\mathrm{z}$ art. 10 konstytucji, jest bowiem także sui generis normą kompetencyjną i musi prowadzić do widzenia w nim możliwości (podstawy prawnej) oparcia pewnego działania publicznego (władczego), w braku norm kompetencyjnych niejako sensu stricto. Odmowa uznania w art. 10 tego rodzaju normy kompetencyjnej oznaczałaby sprowadzenie go do rangi jedynie pewnej wartości konstytucyjnej, gdyż w strukturze konstytucji z 1997 r. nie odgrywa on nawet roli systematyzującej. Natomiast możliwości podejmowania działań, leżących na «obrzeżach» danej władzy, należy już wykluczyć, gdyż mogą one być realizowane przez różne władze (w rozumieniu organizacyjnym) i w takich sytuacjach wymóg wyraźnego i jednoznacznego określenia kompetencji występuje w całej rozciągłości” (P. Sarnecki, Komentarz do art. 10 [w:] Konstytucja Rzeczypospolitej Polskiej. Komentarz, red. L. Garlicki, M. Zubik, t. I, Warszawa 2016, s. 348-349).

3.3. Trybunał Konstytucyjny wielokrotnie wypowiadał się na temat zasady podziału i równowagi władz. Zgodnie z poglądem TK, „art. 10 Konstytucji, statuujący zasadę podziału i równowagi władz, jest zasadą ustrojową odnoszącą się do relacji pomiędzy organami władzy ustawodawczej, władzy wykonawczej oraz 
władzy sądowniczej w systemie konstytucyjnym Rzeczypospolitej Polskiej. Zasada zawarta w art. 10 Konstytucji (podziału i równowagi władz) jest - co należy podkreślić - zasadą ustroju wewnętrznego RP” (wyrok TK z 11 maja 2005 r., sygn. akt K 18/04).

Istotna, z punktu widzenia oceny zasady podziału i równowagi władz, wypowiedź Trybunału Konstytucyjnego została wyartykułowana w uzasadnieniu wyroku z 9 listopada 2005 r., sygn. akt Kp 2/05, w kontekście badania konstytucyjności ustawy o finansach publicznych, mianowicie TK stwierdził, że: „[w]yrażona przez art. 10 Konstytucji zasada podziału władzy ustawodawczej, wykonawczej i sądowniczej dotyczy przede wszystkim zachowania istotnych atrybutów każdej z tych władz. Takim atrybutem władzy sądowniczej jest, $\mathrm{w}$ jej segmencie sądowym, kompetencja do sprawowania wymiaru sprawiedliwości w celu realizacji przysługującego każdemu podmiotowego prawa do sądu (art. 45 Konstytucji). Jeśli chodzi o Trybunał Konstytucyjny - to jego rola jako części władzy sądowniczej wyraża się w kompetencji do rozstrzygania w przedmiocie hierarchicznej zgodności norm prawnych. Kompetencje budżetowe sądów i trybunałów nie odnoszą się bezpośrednio ani do sprawowania wymiaru sprawiedliwości przez sądy, ani do wykonywania funkcji orzeczniczej przez TK; nie mają zatem znaczenia przesądzającego dla zachowania niezależności sądów i niezawisłości sędziów. Mają jednak pewne znaczenie z punktu widzenia zachowania równowagi władz mającej na celu ich harmonijne współdziałanie. Zatem zgodności zaskarżonych przepisów $\mathrm{z}$ art. 10 Konstytucji Trybunał nie bada $\mathrm{z}$ punktu widzenia podziału władz, lecz ich równowagi i współdziałania. Równowaga tych trzech władz, w świetle art. 10 Konstytucji, jest zasadą konstytucyjną" (wyrok TK z 9 listopada 2005 r., sygn. akt Kp 2/05).

Trybunał Konstytucyjny wyraził również pogląd, że: „Zgodnie z konstytucyjną zasadą podziału władzy ustrój Rzeczypospolitej Polskiej opiera się na podziale i równowadze władzy ustawodawczej, władzy wykonawczej i władzy sądowniczej (art. 10 ust. 1 Konstytucji). Władzę ustawodawczą sprawują Sejm i Senat, władzę wykonawczą Prezydent Rzeczypospolitej Polskiej i Rada Ministrów, a władzę sądowniczą sądy i trybunały (art. 10 ust. 2 Konstytucji).

Podział władzy oznacza, m.in., że każdej z trzech władz powinny przypadać kompetencje materialnie odpowiadające ich istocie, a co więcej - każda $\mathrm{z}$ trzech władz powinna zachowywać pewne minimum kompetencyjne stanowiące o zachowaniu tej istoty (zob. orzeczenie z 21 listopada 1994 r., sygn. K 6/94, OTK w 1994 r., cz. II, poz. 39). Kształtując kompetencje poszczególnych organów państwowych, ustawodawca nie może naruszyć »istotnego zakresu« danej władzy (zob. orzeczenie z 22 listopada 1995 r., sygn. K 19/95, OTK w 1995 r., cz. II, poz. 35). Zakaz ingerencji $\mathrm{w}$ istotę danej władzy wyznacza nie tylko zasady kształtowania zakresu kompetencji organów państwowych w ustawodawstwie, ale również sposób korzystania z kompetencji przyznanych poszczególnym organom państwowym. 
Z kolei równowaga władz zakłada możliwość ich oddziaływania na siebie, wzajemne uzupełnianie swych funkcji przez organy i wyraża się zarówno we współpracy władz ze sobą, jak i w ich wzajemnej kontroli (zob. wyrok z 15 stycznia 2009 r., sygn. K 45/07, OTK ZU nr 1/A/2009, poz. 3).

Podział i równowaga władz muszą być interpretowane $\mathrm{z}$ uwzględnieniem treści art. 173 Konstytucji, który stanowi, że »Sądy i Trybunały są władzą odrębną i niezależną od innych władz«. To znaczy, że w stosunkach między władzą ustawodawczą a wykonawczą możliwe są różne formy wzajemnych oddziaływań i współpracy oraz dopuszcza się istnienie obszaru, w którym kompetencje organów należących do obu władz »przecinają się« lub »nakładają«. Natomiast relacje między władzą sądowniczą a pozostałymi muszą opierać się na zasadzie »separacji«, która zakłada przede wszystkim oddzielenie organizacyjne i funkcjonalne sądownictwa od organów innych władz, tak aby zapewnić sądom pełną samodzielność w zakresie rozpoznawania spraw i orzekania (zob. wyrok z 14 kwietnia 1999 r., sygn. K 8/99, OTK ZU nr 3/1999, poz. 41).

Odrębność władzy sądowniczej przejawia się w jej szczególnych kompetencjach, polegających na sprawowaniu wymiaru sprawiedliwości. Sam jednak podział władz nie eliminuje wszelkich powiązań między władzami. Sędziów powołuje Prezydent RP, jako organ władzy wykonawczej, a podstawę działalności sądów stanowią akty parlamentu, a więc władzy ustawodawczej. Wskazane powiązania nie mogą naruszać odrębności władzy sądowniczej, co oznacza, że pozostałym władzom nie można powierzać wymiaru sprawiedliwości (zob. wyrok z 19 lipca 2005 r., sygn. K 28/04, OTK ZU nr 7/A/2005, poz. 81)" (wyrok TK z 7 października 2014 r., sygn. akt K 9/13).

\section{Artykuł 60 Konstytucji}

Artykuł 60 Konstytucji stanowi: „Obywatele polscy korzystający z pełni praw publicznych mają prawo dostępu do służby publicznej na jednakowych zasadach”.

4.1. Jak podkreśla się w doktrynie, „dla wykładni art. 60 konstytucji kluczowe znaczenie ma ustalenie znaczenia terminu »służba publiczna«. Zakres tego pojęcia wyznacza zakres stosowania gwarancji konstytucyjnych zawartych w komentowanym przepisie. Według powszechnie akceptowanej opinii ani konstytucja, ani polskie prawo w ogólności nie stwarzają wystarczających podstaw dla zbudowania precyzyjnej definicji służby publicznej (zob. M. Jabłoński, Prawo dostępu do stużby publicznej, [w:] Prawa i wolności obywatelskie w Konstytucji RP, red. B. Banaszak, A. Preisner, Warszawa 2002, s. 627; Z. Witkowski, Prawo dostępu do służby publicznej, [w:] Wolności i prawa polityczne, red. W. Skrzydło, Kraków 2002, s. 193-194). Przymiot publiczności - w kontekście służby - można wyjaśniać przez uwzględnienie jego występowania w konstytucji w powiązaniu $\mathrm{z}$ innymi jeszcze niż służba wyrażeniami, jak: »instytucja publiczna« (preambuła); "władza publiczna» (art. 7, art. 15, art. 30, art. 51 ust. 2, art. 61 ust. 1 i 2, art. 63, art. 68 ust. $2-5$, art. 70 ust. 3 i 4, art. 71, art. 72 ust. 2 i 3, art. 74 ust. 1, 2 i 4, art. 75 
ust. 1 , art. 76, art. 77 ust. 1, art. 80, art. 123 ust. 1, art. 163, art. 228 ust. 3, art. 238 ust. 1, 2 i 3); »administracja publiczna « (art. 71 ust. 1), a także »działalność publiczna« (art. 178, art. 195 ust. 3, art. 205 ust. 3, art. 209 ust. 3, art. 214 ust. 2); »funkcja publiczna« (art. 61 ust. 1, art. 103 ust. 3, art. 132), "godność publiczna« (art. 33); »obowiązki publiczne« (członka Rady Ministrów) (art. 150).

W tym kontekście pojęciu »służba publiczna« wyznacza granice, po pierwsze, okoliczność, że służba ta polega na udziale w działalności instytucji publicznych, a przede wszystkim i najczęściej, instytucji władzy publicznej, tzn. państwowych (a nie tylko rządowych) oraz samorządu terytorialnego [...]. Pojęcie »służba publiczna « w znaczeniu podmiotowym (strukturalnym) znaczy to samo, co służba w instytucjach publicznych. Po drugie, udział w działalności instytucji publicznej, aby mieścił się w definicji służby publicznej, musi być trwały, a nie doraźny, zaś związek danej osoby z tą instytucją - aby można było zakwalifikować go jako służbę publiczną - mieć charakter pracowniczy lub quasi-pracowniczy, bez względu zresztą na formę jego nawiązania oraz nazwę stanowiska [...]. W zwrocie »służba publiczna« przez służbę należy rozumieć trwałe [...] powiązanie natury organizacyjnej lub tylko funkcjonalnej, najczęściej - ale niekoniecznie stosunkiem pracy z instytucją o charakterze publicznym. Nie musi to być zatem umowny stosunek pracy w ścisłym tego słowa znaczeniu.

W tej sytuacji pojęcie »służba publiczna« należy rozumieć szeroko, nadając mu charakter pojęcia zbiorczego, obejmującego bardzo różne rodzajowo postaci tej służby [...]. Służbą publiczną będzie trwałe wykonywanie wszelkich zajęć związanych bezpośrednio lub tylko pośrednio z realizacją zadań władzy publicznej, wypełnianiem funkcji publicznych oraz/lub zaspokajaniem potrzeb publicznych (powszechnych, masowych, powtarzalnych) oraz/lub działanie w interesie publicznym (zob. art. 22, art. 213 ust. 1) bądź dla osiągnięcia celu publicznego (art. 216 ust. 2). Szerokie rozumienie służby publicznej przyjmuje orzecznictwo Trybunału Konstytucyjnego. Organ ten wyraził m.in. pogląd, że »użyte na gruncie art. 60 ustawy zasadniczej pojęcie 'służby publicznej' ma szerokie - konstytucyjnoprawne znaczenie. Obejmuje tym samym ogół stanowisk w organach władzy publicznej, w tym m.in. w pochodzących $\mathrm{z}$ wyborów organach stanowiących jednostek samorządu terytorialnego " (wyrok z 23 marca 2010 r., K 19/09)" (W. Sokolewicz, K. Wojtyczek, Komentarz do art. 60 [w:] Konstytucja Rzeczypospolitej Polskiej. Komentarz, red. L. Garlicki, M. Zubik, t. II, Warszawa 2016, s. 441-442).

4.2. Trybunał Konstytucyjny wielokrotnie wypowiadał się na temat prawa równego dostępu do służby publicznej, wynikającego z art. 60 Konstytucji. Stwierdził m. in., że „artykuł 60 Konstytucji gwarantuje zatem każdemu obywatelowi korzystającemu z pełni praw publicznych prawo do ubiegania się o przyjęcie do służby publicznej. Jak stwierdził Trybunał Konstytucyjny w wyroku z 9 czerwca 1998 r. (sygn. K 28/97) nie oznacza to, że każda osoba posiadająca obywatelstwo polskie i pełnię praw publicznych ma zostać przyjęta do służby publicznej na 
swój wniosek. Do państwa należy bowiem określenie liczby stanowisk w służbie publicznej oraz warunków wymaganych do ich uzyskania. Art. 60 Konstytucji wymaga, aby zasady dostępu do służby publicznej były takie same dla wszystkich obywateli korzystających z pełni praw publicznych. Ustawa musi zatem ustanowić obiektywne kryteria doboru kandydatów do tej służby oraz uregulować zasady i procedurę rekrutacji w taki sposób, aby zapewnić przestrzeganie zasady równości szans wszystkich kandydatów, bez jakiejkolwiek dyskryminacji i nieuzasadnionych ograniczeń. Nie odbiera to wszelako władzy publicznej możliwości ustalenia szczegółowych warunków dostępu do konkretnej służby, ze względu na jej rodzaj i istotę. W systemach demokratycznych zasadą jest selekcyjny charakter naboru do służby publicznej. Ustawa powinna również określić kryteria zwalniania ze służby oraz procedurę podejmowania decyzji w tym zakresie, tak aby wykluczyć wszelką dowolność działania władz publicznych. Konieczne jest także stworzenie odpowiednich gwarancji praworządności decyzji dotyczących dostępu do służby publicznej, a więc przede wszystkim decyzji o przyjęciu lub odmowie przyjęcia do służby publicznej oraz zwolnieniu z tej służby (OTK ZU nr 4/1998, poz. 50, s. 302)" (wyrok TK z 13 lutego 2007 r., sygn. akt K 46/05).

Problem przestrzegania konstytucyjnej zasady równego dostępu do służby publicznej w kontekście powierzenia Krajowej Radzie Sądownictwa kompetencji do ustalania kryteriów oceny kandydatów na sędziów, na gruncie ustawy z dnia 27 lipca 2001 r. o Krajowej Radzie Sądownictwa (Dz. U. Nr 100, poz. 1082, ze zm.), był przedmiotem oceny Trybunału Konstytucyjnego, który stwierdził, że „należy zwrócić uwagę, że Konstytucja stanowi w art. 60, że obywatele polscy korzystający z pełni praw publicznych mają prawo dostępu do służby publicznej na jednakowych zasadach. Trybunał Konstytucyjny przypominał znaczenie tego przepisu w wielu orzeczeniach. Zgodnie z ustalonym orzecznictwem Trybunału Konstytucyjnego, przepis ten gwarantuje każdemu obywatelowi, korzystającemu z pełni praw publicznych, prawo ubiegania się o przyjęcie do służby publicznej, nie gwarantuje natomiast przyjęcia do tej służby. Ustawodawca uprawniony jest bowiem do sformułowania dodatkowych warunków, uzależniając od ich spełnienia uzyskanie określonych stanowisk w służbie publicznej z uwzględnieniem ich rodzaju oraz istoty. Organy władzy publicznej muszą ponadto określić liczbę obsadzanych stanowisk stosownie do potrzeb państwa. W tym kontekście podstawowym celem art. 60 Konstytucji jest zapewnienie równości szans dla osób podejmujących starania o pełnienie funkcji w służbie publicznej. Analizowany przepis z jednej strony wymaga od ustawodawcy ustanowienia regulacji materialnoprawnych określających przejrzyste kryteria selekcji kandydatów i obsadzania poszczególnych stanowisk w służbie publicznej, a z drugiej strony nakazuje stworzenie odpowiednich gwarancji proceduralnych, zapewniających weryfikowalność decyzji w sprawie naboru do służby. Brak odpowiednich procedur kontrolnych i odwoławczych stanowić może istotną przeszkodę w stosowaniu przyjętych reguł, a tym samym naruszać będzie konstytucyjny wymóg 
traktowania starających się o dostęp do służby na jednakowych zasadach (por. w szczególności wyroki: z 9 czerwca 1998 r., sygn. K 28/97, OTK ZU nr 4/1998, poz. 50, z 14 grudnia 1999 r., sygn. SK 14/98, OTK ZU nr 7/1999, poz. 163, z 8 kwietnia 2002 r., sygn. SK 18/01, OTK ZU nr 2/A/2002, poz. 16). Art. 60 Konstytucji stanowi źródło precyzyjnie określonych konstytucyjnych praw podmiotowych, które muszą być przestrzegane przez organy władzy publicznej.

Zdaniem Trybunału regułą powinien być dostęp do stanowisk w służbie publicznej w drodze konkursu przeprowadzanego na podstawie jasnych określonych w ustawie kryteriów. Takie rozwiązanie odpowiada nie tylko wymogom sprawiedliwości, wykluczając arbitralność rozstrzygnięć, ale ponadto służy realizacji dobra wspólnego, umożliwiając nabór najlepszych kandydatów na poszczególne stanowiska w służbie publicznej. Ustawodawca powinien dążyć do coraz szerszego wprowadzania procedury konkursowej przy obsadzaniu stanowisk w służbie publicznej.

Nie podlega dyskusji, że prawo dostępu do służby publicznej obejmuje także stanowiska sędziowskie. Szczególna ranga oraz rola sądów w zakresie realizacji konstytucyjnych wolności i praw wymaga, aby przedstawione wyżej zasady konstytucyjne były respektowane w sposób szczególnie skrupulatny przy obsadzaniu stanowisk sędziowskich. Biorąc pod uwagę konstytucyjną zasadę niezawisłości sędziów, należy wykluczyć wszelką arbitralność i dowolność w tym zakresie.

Art. 60 Konstytucji nie gwarantuje prawa do awansu osobom przyjętym do służby publicznej. $\mathrm{Z}$ drugiej jednak strony ubieganie się o przeniesienie na wyższe stanowisko zbiega się $\mathrm{z}$ reguły $\mathrm{z}$ kandydowaniem na to stanowisko nie tylko osób, które już zostały przyjęte do służby publicznej, ale także osób, które ubiegają się o dane stanowisko, nie należąc jeszcze do służby publicznej. $Z$ tego względu konstytucyjne prawo dostępu do służby publicznej musi zostać odniesione do poszczególnych rodzajów stanowisk w obrębie służby publicznej. Rozważane prawo obejmuje nie tylko ogólne prawo do ubiegania się o przyjęcie do służby publicznej w ogóle, ale także prawo do ubiegania się o określone stanowisko w obrębie tej służby, a przedstawione wyżej gwarancje dotyczące dostępu do służby publicznej muszą odnosić się do procedur obsadzania poszczególnych rodzajów stanowisk w służbie publicznej. Gwarancje te zapewniają jednakową ochronę kandydatów już zatrudnionych w służbie publicznej i kandydatów spoza tej służby. Nie podlega dyskusji, że zaskarżone regulacje dotyczące powoływania i awansowania sędziów dotykają prawa dostępu do służby publicznej.

Kryteria oceny kandydatów na sędziów stanowią materię o szczególnym znaczeniu z punktu widzenia realizacji konstytucyjnego prawa dostępu do służby publicznej. Z tego względu podstawowe kryteria selekcji kandydatów powinny być określone $\mathrm{w}$ samej ustawie. Ustawodawca powinien przy tym preferować konkursowe procedury naboru do służby publicznej oparte na obiektywnych kryteriach zdefiniowanych przez ustawę" (wyrok TK z 29 listopada 2007 r., sygn. akt SK 43/06). 
W wyroku z 27 maja 2008 r., sygn. SK 57/06 Trybunał Konstytucyjny stwierdził, że „prawo wynikające z art. 60 Konstytucji ma charakter gwarancji formalnej, jako że normy konstytucyjne, poza wymogiem obywatelstwa polskiego, nie określają przesłanek, jakie muszą być spełnione przez osoby ubiegające się o stanowisko w służbie publicznej. Przepis ten nie może być zatem podstawą dochodzenia przed sądem roszczenia o dopuszczenie do pracy czy pełnienie konkretnej funkcji, zajmowanie określonego stanowiska. Dobrem chronionym przez art. 60 Konstytucji jest przejrzystość i jawność reguł stosowanych przy określaniu wymagań związanych $z$ objęciem funkcji w służbie publicznej. W prawie gwarantowanym tym przepisem Konstytucji mieści się również weryfikowalność stosowanych kryteriów naboru do służby - władza publiczna uprawniona jest do ustalania szczególnych warunków dostępu do konkretnej służby, a więc selekcyjnego naboru do służby publicznej. Konieczne jest jednak stworzenie odpowiednich gwarancji praworządności decyzji dotyczących dostępu do służby publicznej, tak aby wykluczyć wszelką dowolność działania władzy publicznej (por. wyrok z 9 czerwca 1998 r., sygn. K 28/97). W przywołanym wcześniej wyroku z 29 listopada 2007 r. (sygn. SK 43/06), Trybunał stwierdził również, że nie ulega wątpliwości, iż prawo dostępu do służby publicznej obejmuje także stanowiska sędziowskie. "Szczególna ranga oraz rola sądów w zakresie realizacji konstytucyjnych wolności i praw wymaga, aby przedstawione wyżej zasady konstytucyjne były respektowane w sposób szczególnie skrupulatny przy obsadzaniu stanowisk sędziowskich. Biorąc pod uwagę konstytucyjną zasadę niezawisłości sędziów, należy wykluczyć wszelką arbitralność i dowolność w tym zakresie. Art. 60 Konstytucji nie gwarantuje prawa do awansu osobom przyjętym do służby publicznej. Z drugiej jednak strony ubieganie się o przeniesienie na wyższe stanowisko zbiega się z reguły z kandydowaniem na to stanowisko nie tylko osób, które już zostały przyjęte do służby publicznej, ale także osób, które ubiegają się o dane stanowisko, nie należąc jeszcze do służby publicznej. Z tego względu konstytucyjne prawo dostępu do służby publicznej musi zostać odniesione do poszczególnych rodzajów stanowisk w obrębie służby publicznej. Rozważane prawo obejmuje nie tylko ogólne prawo do ubiegania się o przyjęcie do służby publicznej w ogóle, ale także prawo do ubiegania się o określone stanowisko w obrębie tej służby, a przedstawione wyżej gwarancje dotyczące dostępu do służby publicznej muszą odnosić się do procedur obsadzania poszczególnych rodzajów stanowisk w służbie publicznej. Gwarancje te zapewniają jednakową ochronę kandydatów już zatrudnionych w służbie publicznej i kandydatów spoza tej służby«.

Trybunał Konstytucyjny podkreślał wielokrotnie, że art. 60 Konstytucji nie gwarantuje przyjęcia do służby publicznej, gwarantuje jednak każdemu obywatelowi, korzystającemu z pełni praw publicznych, prawo dostępu do służby publicznej na jednakowych zasadach. Z art. 60 Konstytucji wynika więc konstytucyjne prawo każdego do ubiegania się o przyjęcie do służby publicznej na jednakowych zasadach. Ustawodawca uprawniony jest do sformułowania szcze- 
gółowych warunków, uzależniając od ich spełnienia ubieganie się o określone stanowiska w służbie publicznej, z uwzględnieniem rodzaju stanowiska oraz jego charakteru. Organy władzy publicznej muszą ponadto określić liczbę obsadzanych stanowisk stosownie do potrzeb państwa. W tym kontekście celem art. 60 Konstytucji jest zapewnienie równości szans dla osób podejmujących starania o pełnienie funkcji w służbie publicznej; realizacja art. 60 Konstytucji z jednej strony wymaga od ustawodawcy ustanowienia regulacji materialnoprawnych, określających przejrzyste kryteria selekcji kandydatów i obsadzania poszczególnych stanowisk w służbie publicznej, a z drugiej strony nakazuje stworzenie odpowiednich gwarancji proceduralnych, zapewniających weryfikowalność decyzji w sprawie naboru do służby" (wyrok TK z 27 maja 2008 r., sygn. akt SK 57/06).

\section{Artykuł 144 ust. 3 pkt 17 Konstytucji}

Artykuł 144 ust. 3 pkt 17 Konstytucji stanowi: „Przepis ust. 2 [zgodnie z którym »akty urzędowe Prezydenta Rzeczypospolitej wymagają dla swojej ważności podpisu Prezesa Rady Ministrów, który przez podpisanie aktu ponosi odpowiedzialność przez Sejmem «- uzupełnienie J.P.] nie dotyczy: [... 17) powoływania sędziów".

5.1. Artykuł 144 ust. 3 pkt 17 Konstytucji wskazuje na jeden z aktów urzędowych Prezydenta Rzeczypospolitej, który nie wymaga kontrasygnaty, którym jest powoływanie sędziów. Jest to jedna z prerogatyw prezydenckich.

5.2. W odniesieniu do art. 144 ust. 3 Konstytucji Trybunał Konstytucyjny stwierdził, że „kontrasygnata nie jest wymagana, gdy dotyczy aktów wymienionych $w$ art. 144 ust. 3 Konstytucji. Trybunał Konstytucyjny stwierdza, że brak jest podstaw do uznania, że uprawnienia Prezydenta wykonywane na podstawie art. 144 ust. 3 Konstytucji mogą być rozszerzane drogą ustawową na zasadzie »dalszego ciągu « aktu zwolnionego z kontrasygnaty czy na zasadzie kompetencji analogicznych.

Art. 144 ust. 3 Konstytucji jest jednym z kluczowych przepisów kształtujących ustrojową rolę Prezydenta w systemie konstytucyjnym. Określa on zakres uprawnień Prezydenta realizowanych poza systemem kontroli politycznej Sejmu, i w tym względzie Konstytucja nie dopuszcza żadnych odstępstw. Trybunał Konstytucyjny wielokrotnie wyrażał pogląd, że kompetencje organów nie mogą być wywodzone na zasadzie analogii, lecz zawsze muszą mieć podstawę w wyraźnie sformułowanym przepisie prawa. Zasada ta odnosi się w szczególności do takich kompetencji organu konstytucyjnego, które mają charakter wyjątku od reguły działania tego organu" (wyrok TK z 23 marca 2006 r., sygn. akt K 4/06).

\section{- 6. Artykuł 173 Konstytucji}

Artykuł 173 Konstytucji stanowi: „Sądy i Trybunały są władzą odrębną i niezależną od innych władz". 
6.1. Jak podkreśla doktryna, art. 173 Konstytucji „określa relację władzy sądowniczej w stosunku do pozostałych władz. Stanowi rozwinięcie postanowień zawartych w art. 10 Konstytucji RP, wprowadzających w Polsce system trójpodziału władzy (odwołanie wewnętrzne do art. 10). Zgodnie z ust. 2 art. 10 Konstytucji RP władzę sądowniczą sprawują sądy i trybunały. Przepisy te określają pozycję ustrojową sądów w strukturze organów państwa. Natomiast art. 173 Konstytucji RP określa wzajemną relację zachodzącą między władzą sądowniczą a pozostałymi rodzajami władzy. Stwierdzenie, że sądy i trybunały są władzą odrębną i niezależną od innych władz, stanowi także emanację zasady równowagi władz wyrażonej w art. 10 ust. 1 Konstytucji RP” (P. Wiliński, P. Karlik, Art. 173 [w:] Konstytucja RP, t. II, Komentarz. Art. 87-243, red. M. Safjan, L. Bosek, Warszawa 2016, nb. 1).

Wyjaśniając znaczenie wyrażenia „odrębność i niezależność sądów i Trybunałów od pozostałych władz”, należy stwierdzić, że oznacza ono, że przyznane tym podmiotom „uprawnienia i kompetencje nie mogą być wykonywane przez inne podmioty (wyr. TK z: 19.7.2005 r., K 28/04, OTK-A 2005, Nr 7, poz. 81; 29.11.2005 r., P 16/04, OTK-A 2005, Nr 10, poz. 119). Przepis art. 173 Konstytucji RP nie pozostawia w tym zakresie jakiegokolwiek pola do interpretacji czy wątpliwości. Niedopuszczalna jest jakakolwiek ingerencja innych władz w sprawy objęte monopolem sądów w zakresie sprawowania wymiaru sprawiedliwości (»jądro kompetencyjne«) (wyr. TK z 7.11.2013 r., K 31/12, OTK-A 2013, Nr 8, poz. 121), a także niestanowiących wymiaru sprawiedliwości, ale przekazanych do jurysdykcji tych sądów i Trybunałów.

Odrębność władzy sądowniczej oznacza jednocześnie wydzielenie organizacyjne spośród innych władz [...]. Jej naturalną konsekwencją jest konieczność zapewnienia sądom i trybunałom należytych warunków funkcjonowania, adekwatnych do zakresu kompetencji, jurysdykcji i zapewniających efektywność tej działalności. Sposób dokonywania tej oceny oraz określenia rodzaju, ilości i jakości potrzeb pozostawać musi w zgodzie z nadrzędnymi regułami konstytucyjnej niezależności sądów i trybunałów, a zatem nie może stanowić ukrytego mechanizmu nacisku na organy władzy sądowniczej.

Za B. Banaszakiem warto zwrócić uwagę także na uzupełniające elementy wyznaczające odrębność i niezależność władzy sądowniczej. Autor zalicza do nich, poza oddzieleniem organizacyjnym sądów i trybunałów, także: pozostawienie wyłącznie sądowi decydowania o tym, czy sprawa należy do jego kompetencji; udział samorządu sędziowskiego w wybieraniu prezesów sądu; obywatelskie prawo do sądu; zapewnienie środków finansowych gwarantujących funkcjonowanie sądów i trybunałów; dopuszczalność ingerencji pozostałych władz jedynie w działalność pozaorzeczniczą oraz gwarancje o charakterze procesowym i te dotyczące pozycji sędziego (zob. Banaszak, Konstytucja, 2012, s. 871-871 [B. Banaszak, Konstytucja Rzeczypospolitej Polskiej. Komentarz, Warszawa 2012 - uzupełnienie J.P.]). 
Należy jednocześnie pamiętać, że odrębność i niezależność nie oznacza całkowitego zerwania jakichkolwiek relacji zachodzących pomiędzy władzą sądowniczą a władzą ustawodawczą i wykonawczą. Przede wszystkim należy zwrócić uwagę na treść art. 10 ust. 1 Konstytucji RP, w myśl którego ustrój Rzeczypospolitej opiera się na podziale, ale i równowadze wszystkich rodzajów władzy" (P. Wiliński, P. Karlik, Art. 173, [w:] Konstytucja RP, op. cit., nb. 22-23).

6.2. Trybunał Konstytucyjny, w kontekście oceny zgodności z Konstytucją przepisów upoważniających Ministra Sprawiedliwości do odwoływania prezesa sądu, stwierdził, że „art. 173 Konstytucji, w którym mowa o sądach i trybunałach, jako władzy odrębnej i niezależnej od innych władz, nie znosi podstawowej zasady ustrojowej Rzeczypospolitej Polskiej podziału i równowagi władzy ustawodawczej, wykonawczej i sądowniczej, ani też w żadnym stopniu jej nie modyfikuje. Należy także mieć na uwadze, że rozdzielone władze nie są tym samym niezależnymi od siebie elementami ustroju państwa. Stanowią one w istocie rzeczy jedną konstrukcję, w ramach której obowiązane są współdziałać w celu zapewnienia rzetelności i sprawności instytucji publicznych (zasada współdziałania określona w preambule do Konstytucji). Innymi słowy, odrębność i niezależność sądów nie może prowadzić do zniesienia mechanizmu koniecznej równowagi pomiędzy wszystkimi tymi władzami. Każda z nich powinna dysponować natomiast takimi instrumentami, które "pozwalają jej powstrzymywać, hamować działania pozostałych, zarazem muszą istnieć instrumenty, które pozwalają innym władzom powstrzymywać, hamować jej działania [...] Zasada ta, wyrażana także znaną formułą checks and balance, jest jedną z najstarszych zasad ustrojowych i zarazem jedną z najistotniejszych i najlepiej sprawdzonych w praktyce reguł demokracji.

$\mathrm{Z}$ drugiej jednak strony należy mieć na uwadze, że każda $\mathrm{z}$ wymienionych władz ma swoje jak gdyby »jądro kompetencyjne«, w które inne władze nie mogą wkraczać, gdyż oznaczałoby to przekreślenie zasady ich podziału [...]. Jest w tym kontekście poza sporem, że mechanizm hamowania i równowagi, zakładający możliwość ingerencji w zakres władzy sądowniczej nie może dotykać niezawisłości sędziowskiej w zakresie sprawowania urzędu, a jakiekolwiek wkraczanie w działanie i organizację władzy sądowniczej, w sferze nie objętej bezwzględną zasadą niezawisłości, może być dokonywane jedynie wyjątkowo i posiadać dostateczne uzasadnienie merytoryczne (por. orzeczenie Trybunału Konstytucyjnego w sprawie K 11/93)" (wyrok TK z 18 lutego 2004 r., sygn. akt K 12/03).

\section{- 7. Artykuł 178 Konstytucji}

Artykuł 178 stanowi: „1. Sędziowie w sprawowaniu swojego urzędu są niezawiśli i podlegają tylko Konstytucji oraz ustawom. 2. Sędziom zapewnia się warunki pracy i wynagrodzenie odpowiadające godności urzędu oraz zakresowi ich obowiązków. 3. Sędzia nie może należeć do partii politycznej, związku zawodowego ani prowadzić działalności publicznej nie dającej się pogodzić z zasadami niezależności sądów i niezawisłości sędziów." 
7. 1. Pojęcie niezawisłości sędziowskiej zostało „użyte w Konstytucji RP bez bliższego zdefiniowania, ale nie ulega wątpliwości, że ustawodawca konstytucyjny posłużył się »terminem zastanym «, którego znaczenie uformowało się jeszcze w Polsce międzywojennej. W piśmiennictwie wskazuje się, że na niezawisłość składają się następujące elementy: 1) bezstronność w stosunku do uczestników postępowania; 2) niezależność wobec organów (instytucji) pozasądowych; 3 ) samodzielność sędziego wobec władz i innych organów sądowych; 4) niezależność od wpływu czynników politycznych, zwłaszcza partii politycznych; 5) wewnętrzna niezależność sędziego. Poszanowanie i obrona tych wszystkich elementów niezawisłości są konstytucyjnym obowiązkiem wszystkich organów i osób stykających się z działalnością sądów, a także są konstytucyjnym obowiązkiem samego sędziego [...]. W komentowanym przepisie ustawodawca konstytucyjny posługuje się autonomicznym wobec »wymierzania sprawiedliwości« pojęciem »sprawowanie urzędu «, co oznacza, że zasada niezawisłości odnosi się do wszystkich działań sędziego związanych z procesem orzekania oraz działań podejmowanych w związku z procesem orzekania (np. ustalania abstrakcyjnej wykładni ustaw), jak również do działań podejmowanych przez sądy w formach orzeczniczych, lecz nie traktowanych jako wymierzanie sprawiedliwości (np. rozstrzyganie o ważności wyborów) oraz do wszystkich sytuacji, gdy sędzia - jako osoba zaufania publicznego - zostanie powołana do składu organów pozasądowych, np. do komisji wyborczych" (M. Masternak-Kubiak, Art. 178. Sędziowie; niezawisłość sędziowska [w:] Konstytucja Rzeczypospolitej Polskiej. Komentarz, red. M. Haczkowska, Warszawa 2014, s. 441).

7.2. Określając zakres przedmiotowy oddziaływania niezawisłości sędziowskiej „należy zwrócić uwagę na wykorzystany przez ustawodawcę zwrot »sprawowanie urzędu «. Zgodnie bowiem z art. 178 ust. 1 Konstytucji RP niezawisłość jest atrybutem sędziego w »sprawowaniu swojego urzędu «. Wykorzystanie przez ustrojodawcę tego pojęcia traktować należy jako zabieg celowy, mający podkreślić różnicę pomiędzy zakresem sprawowania urzędu sędziego a pojęciem sprawowania przez sędziego wymiaru sprawiedliwości. [...] pojęcie sprawowania urzędu sędziego ma szerszy charakter aniżeli pojęcie sprawowania wymiaru sprawiedliwości. Dotyczy czynności z zakresu orzekania oraz wszelkich działań podejmowanych w związku z tymi czynnościami, które jednak takiego charakteru nie mają. Należy tutaj wskazać przede wszystkim na aktywność organizacyjną związaną z orzekaniem [M. Masternak-Kubiak, w: M. Haczkowska (red.), Konstytucja, s. 441]. Kwestia ta nie jest jednak oceniania jednoznacznie. B. Naleziński podkreśla, że zwrotu w »sprawowaniu swojego urzędu« nie należy rozumieć zbyt szeroko, gdyż odnosi się on jedynie do płaszczyzny orzeczniczej, nie obejmując czynności związanych z administracją sądową (B. Naleziński, w: P. Sarnecki (red.), Prawo konstytucyjne [Prawo konstytucyjne Rzeczypospolitej Polskiej], [Warszawa - uzupełnienie J.P.] 2002, s. 392). Z kolei L. Garlicki stoi na stanowisku, że omawiany zwrot powinien być interpretowany szeroko, ponie- 
waż w zdecydowany sposób wykracza poza konstytucyjne pojęcie wymierzania sprawiedliwości (L. Garlicki, Artykut 178, w: L. Garlicki, Konstytucja, t. 4, s. 11 [Konstytucja Rzeczypospolitej Polskiej. Komentarz, t. IV, red. L. Garlicki, Warszawa 2005 - uzupełnienie J.P.]). Jednocześnie autor ten wskazuje, że zasada niezawisłości nie znajduje zastosowania do wszystkich sfer działalności sędziego, wyróżniając m.in. czynności należące do administracji sądowej (L. Garlicki, Artykuł 178, w: L. Garlicki, Konstytucja, t. 4, s. 11). Jeszcze inaczej na ten problem zdaje się zapatrywać TK, który wskazuje, że z faktu, iż część czynności z zakresu administracji sądowej wykonywana jest przez sędziów nie wynika pozbawienie ich niezawisłości w tym zakresie (wyr. TK z 15.1.2009 r., K 45/07, OTK-A 2009, $\mathrm{Nr}$ 1, poz. 3). [...] Pojęcie sprawowania urzędu sędziego mimo wszystko należy interpretować szeroko. $Z$ całą pewnością pojęcie to nie jest ograniczone jedynie do czynności stricte orzeczniczych, stanowiących ściśle wymiar sprawiedliwości. W jego zakres wchodzą czynności stanowiące sprawowanie wymiaru sprawiedliwości, ale jednocześnie mieścić się tu muszą także te sfery działalności sędziego, kiedy działa on zarówno jako członek składu orzekającego nie w ramach czynności orzeczniczych, jak też gdy działa jako organ sądu (przewodniczący wydziału, prezes, sędzia wizytator), oraz $\mathrm{w}$ ramach innych uprawnień przyznanych $\mathrm{w}$ drodze ustawy sądom i sędziom. Uzasadnione jest przyjęcie, że sędzia sprawuje swój urząd także, gdy wykonuje inne powierzone mu zadania i kompetencje, a więc nie jako osoba prywatna, lecz funkcjonariusz państwowy.

Sprawowanie urzędu sędziego ma miejsce zarówno wtedy, gdy sędzia orzeka, a więc bezpośrednio realizuje swoje kompetencje w sprawowaniu wymiaru sprawiedliwości, jak też gdy wypełnia inne obowiązki wynikające z ustawy, a przypisane sędziemu, np. bierze udział w zgromadzeniu sędziów, dokonuje czynności dowodowych na żądanie stron postępowania karnego (m.in. art. $316 \$ 3 \mathrm{KPK}$ ), występuje jako rzecznik dyscyplinarny.

Sprawowanie wszystkich tych funkcji, które wykraczają poza sprawowanie wymiaru sprawiedliwości, nie zawsze co prawda wymaga niezawisłości dla ich skuteczności. Jednak zachodzi zależność odwrotna. Rozszerzenie oddziaływania niezawisłości sędziego na te inne sfery aktywności działa gwarancyjnie i uwalnia sędziego od zagrożeń, których wystąpienie mogłoby wywrzeć wtórnie wpływ na działalność orzeczniczą sędziego. Uwalnia go w każdym razie od możliwości stawiania zarzutu jednoczesnego działania w przestrzeni publicznej w stanie niezawisłości i do niego przeciwnym, co niewątpliwie prowadziłoby do istotnego podważenia zaufania do faktycznej niezawisłości sprawowania funkcji podstawowej.

Nieuzasadnione byłoby jednak odnoszenie zasady niezawisłości do sytuacji, w których sędziowie wykonują czynności przekraczające ich zakres kompetencji dotyczący sprawowania wymiaru sprawiedliwości i wszelkich działań z nim związanych (związanych $\mathrm{z}$ funkcjonowaniem wymiaru sprawiedliwości, działalnością w ramach samorządu zawodowego, innych powiązanych ustawowych obowiązków). Nie obejmuje zatem działalności społecznej, charytatywnej, innej 
niepublicznej, czy prywatnej. Zatem najodpowiedniejsze wydaje się takie interpretowanie zakresu przedmiotowego niezawisłości sędziowskiej, który funkcjonalnie związany jest z powierzonymi sędziom zadaniami” (P. Wiliński, P. Karlik, Art. 178 [w:] Konstytucja RP, t. II, Komentarz. Art. 87-243, red. M. Safjan, L. Bosek, Warszawa 2016, nb. 45-50).

\section{- 8. Artykuł 179 Konstytucji}

Artykuł 179 Konstytucji stanowi: „Sędziowie są powoływani przez Prezydenta Rzeczypospolitej, na wniosek Krajowej Rady Sądownictwa, na czas nieoznaczony".

8.1. W art. 179 Konstytucji ustrojodawca wskazał podmioty biorące udział $\mathrm{w}$ procedurze powoływania sędziego. Zgodnie $\mathrm{z}$ tym przepisem najpierw Krajowa Rada Sądownictwa przedkłada Prezydentowi wniosek, a następnie Prezydent powołuje sędziów. „W świetle art. 179 wniosek pochodzący od KRS jest koniecznym warunkiem powołania określonej osoby do pełnienia urzędu sędziego. Do pełnienia urzędu sędziego może zostać powołana wyłącznie taka osoba, co do której KRS sformułowała odpowiedni wniosek [...]. Wniosek Krajowej Rady jest nie tylko konieczny, lecz także ma charakter konstytutywny, ponieważ dopiero wystąpienie z nim do Prezydenta uruchamia jego kompetencję do powołania danej osoby na urząd sędziego. [...] rozwiązanie to jest wyrazem założenia, że przy powołaniu na urząd sędziego niezbędne jest współdziałanie dwóch konstytucyjnych organów, z których żaden odrębnie nie może spowodować, aby określona osoba została powołana na urząd sędziego. Służy to zapewnieniu właściwej równowagi pomiędzy kompetencjami nominacyjnymi Prezydenta a zasadą niezależności władzy sądowniczej [...]. KRS ma przy tym wyłączną kompetencję, aby wystąpić do Prezydenta $\mathrm{z}$ wnioskiem o powołanie określonej osoby na urząd sędziego. W myśl art. 179 kompetencji takiej nie ma żaden inny konstytucyjny organ. Rozwiązanie to wiąże się z tym, że Konstytucja powierza to Krajowej Radzie należy stanie na straży niezależności sądów i niezawisłości sędziów. Prezydent nie może także powołać osoby, której dotyczy wniosek KRS, do innego sądu lub na inne stanowisko niż wskazane we wniosku [...]. Przepis art. 179 nie przesądza o kształcie etapów poprzedzających złożenie wniosku przez KRS, jak również o kryteriach, jakie powinien spełniać kandydat na urząd sędziego (por. wyr. TK z 8.5.2012 r., K 7/10, OTK-A 2012, Nr 5, poz. 48)" (K. Weitz, Art. 179 [w:] Konstytucja RP, t. II, Komentarz. Art. 87-243, red. M. Safjan, L. Bosek, Warszawa 2016, nb. 11-12).

8.2. Jak podkreśla doktryna, powoływanie sędziów „Konstytucja powierza Prezydentowi. Oznacza to, że sądy nie tylko działają w imieniu państwa, wydając wyroki, ale też państwo, a konkretnie jeden z jego naczelnych organów, powołuje sędziów. Prezydent czyni to na wniosek KRS. Powołuje sędziów na czas nieoznaczony. Konstytucja nie nakłada na Prezydenta obowiązku uzasadnienia zarówno uwzględnienia wniosku KRS, jak i odmowy uczynienia tego. Ustrojodawca czy- 
niąc tak, daje wyraźnie Prezydentowi pełną swobodę zarówno w podejmowaniu decyzji, jak i w określaniu jej przesłanek. [...] Odmowa powołania sędziów nie może być uznana za niezgodną z zasadą podziału władz (art. 10 ust. 1 Konstytucji). Z istoty tej zasady we wszystkich państwach demokratycznych wynika właśnie to, by organ nominacyjny nienależący do władzy sądowniczej nie był związany decyzjami personalnymi organów tej władzy. Elementem zasady równoważenia władz jest to, aby sama władza sądownicza nie decydowała o swoim składzie” (B. Banaszak, Konstytucja Rzeczypospolitej Polskiej. Komentarz, Warszawa 2009, s. 795-799).

Odmiennie na temat związania Prezydenta wnioskiem KRS inni przedstawiciele doktryny uzasadniają „stanowczym brzmieniem art. 179, odwołaniem do relacji między władzami sądowniczą i wykonawczą oraz funkcjami KRS. W treści art. 179 mowa jest wprost o tym, że Prezydent powołuje sędziów, a nie że tylko może ich powołać na wniosek KRS (por. J. Ciapała, Charakter kompetencji, [Charakter kompetencji Prezydenta RP. Uwagi w kontekście kompetencji $w$ zakresie powoływania sędziów, „Przegląd Sejmowy” 2008, nr 4 - uzupełnienie J.P.] s. 38). Władza sądownicza jest władzą odrębną od pozostałych władz, wobec czego ingerencje innych władz, w tym władzy wykonawczej, muszą mieć wyraźną podstawę konstytucyjną, a istniejące przejawy tej ingerencji nie mogą być interpretowane w sposób rozszerzający [por. T. Ereciński, J. Gudowski, J. Iwulski, w: J. Gudowski (red.), Prawo o ustroju sądów powszechnych [Prawo o ustroju sądów powszechnych. Ustawa o Krajowej Radzie Sądownictwa. Komentarz, Warszawa 2009 - uzupełnienie J.P.], s. 186]. KRS jest jedynym organem konstytucyjnym powołanym do stania na straży niezależności sądów i niezawisłości sędziów (art. 186 ust. 1), Prezydent zaś nie dysponuje w swoim zakresie działania taką funkcją (por. J. Ciapała, Charakter kompetencji, s. 34-36). Za nie bez znaczenia uważa się także to, że Konstytucja nie przewiduje wprost takiego aktu, jak odmowa powołania na urząd sędziego, lecz jedynie akt powołania na taki urząd, a jeśli już przyjąć, że akt odmowy powołania jest konstytucyjnie możliwy, wówczas powstaje wspomniany już problem kontrasygnaty Prezesa RM (por. M. Ziółkowski, Prerogatywa Prezydenta RP [Prerogatywa Prezydenta RP do powolywania sędziów (uwagi o art. 144 ust. 3 pkt 17 i art. 179 Konstytucji), „Przegląd Sejmowy” 2013, nr 1 - uzupełnienie J.P.], s. 67). Prezydent ma swojego przedstawiciela w KRS, w związku z czym ewentualne zastrzeżenia co do rozpatrywanych kandydatur może przedstawić przed podjęciem przez Radę uchwały w sprawie wystąpienia z wnioskiem. Powoływany jest też argument odwołujący się do systematyki przepisów konstytucyjnych - skoro art. 179 jest ulokowany wśród przepisów traktujących o pozycji sędziego oraz formalnych i materialnych gwarancjach jego niezawisłości (art. 178, 180 i 181), to kompetencja Prezydenta do powoływania sędziów jest związana nie tyle z jego ustrojowo-polityczną rolą, ile z pozycją władzy sądowniczej i jej odrębnością (zob. J. Ciapała, Charakter kompetencji, s. 40)" (K. Weitz, Art. 179 [w:] Konstytucja RP, op. cit., nb. 15). 


\section{- 9. Artykuł 184 Konstytucji}

Artykuł 184 Konstytucji stanowi: „Naczelny Sąd Administracyjny oraz inne sądy administracyjne sprawują, w zakresie określonym w ustawie, kontrolę działalności administracji publicznej. Kontrola ta obejmuje również orzekanie o zgodności z ustawami uchwał organów samorządu terytorialnego i aktów normatywnych terenowych organów administracji rządowej”.

9.1. Jak słusznie podkreśla doktryna, „zgodnie z art. 175 ust. 1 Konstytucji RP wymiar sprawiedliwości sprawują SN, sądy powszechne, administracyjne i wojskowe. Sądy administracyjne są pionem sądownictwa wyodrębnionym i niezależnym od sądów powszechnych, wojskowych i SN [...]. Ponadto art. 183 ust. 1 Konstytucji RP stanowi, że SN sprawuje nadzór orzeczniczy tylko nad działalnością sądów powszechnych i wojskowych, a nie administracyjnych. Niedopuszczalne byłoby więc wprowadzenie środków prawnych, za pomocą których orzecznictwo NSA mogłoby zostać poddane nadzorowi orzeczniczemu czy instancyjnemu ze strony sądów powszechnych lub SN (np. wprowadzenie nadzwyczajnego środka zaskarżenia kierowanego do SN od orzeczeń NSA). Również uchwały SN nie mają mocy wiążącej wobec sądów administracyjnych" (M. Wiącek, Art. 184 [w:] Konstytucja RP, t. II, Komentarz do art. 87-243, red. M. Safjan, L. Bosek, Warszawa 2016, nb.17).

Zgodnie z art. 184 Konstytucji „to sądy administracyjne są powołane do kontroli działalności administracji publicznej. Przepis ten ma znaczenie dla wykładni art. 177 Konstytucji RP. Kontrola działalności administracji jest sprawą »zastrzeżoną dla właściwości innych sądów«. W przypadku milczenia ustawy sprawa mieszcząca się w pojęciu »kontroli administracji publicznej « należy do właściwości sądu administracyjnego (por. wyr. TK z 15.10.2013 r., P 26/11, OTK-A 2013, Nr 7, poz. 99). Domniemanie właściwości sądów powszechnych, wynikające $\mathrm{z}$ art. 177 Konstytucji RP, nie rozciąga się więc na kontrolę działalności administracji. W takim przypadku $\mathrm{z}$ art. 184 Konstytucji RP wynika domniemanie właściwości sądów administracyjnych" (ibidem, nb.18).

Jednakże doktryna podnosi również, że „nie oznacza to, że między orzecznictwem sądów administracyjnych a orzecznictwem sądów powszechnych i SN nie zachodzą pewne interferencje. Zjawisko to jest nieuniknione $\mathrm{z}$ powodu pojawiających się niekiedy trudności w ścisłym rozgraniczeniu kognicji sądów administracyjnych i powszechnych. Trudności te wiążą się z wzajemnym przenikaniem prawa publicznego i prywatnego, co może rodzić problemy w określeniu rodzaju stosunku prawnego, na tle którego wywiązał się spór. [...] W skrajnym przypadku sporu kompetencyjnego między SN a NSA - które są centralnymi konstytucyjnymi organami państwa - mógłby on zostać rozstrzygnięty przez TK na podstawie art. 189 Konstytucji RP” (ibidem, nb. 19).

Ponadto, jak ustalono w doktrynie, z art. 184 Konstytucji wynika „zasada, że NSA sprawuje nadzór nad działalnością sądów administracyjnych w zakresie orzekania [...]. W konsekwencji ustawodawca jest zobowiązany do wyposażenia 
NSA w odpowiednie kompetencje nadzorcze, w szczególności do uregulowania właściwości NSA do wydawania uchwał i do określenia zakresu mocy wiążącej tych uchwał, tak by nadzór orzeczniczy był realny i efektywny" (ibidem, nb. 21).

Pod pojęciem administracji publicznej „należy zaś rozumieć $\mathrm{w}$ świetle art. $184 \mathrm{zd} .2$ »w zakresie podmiotowym [...] ogół podmiotów wykonujących zadania z zakresu administracji publicznej« (post. WSA w Warszawie z 5.4.2011 r., VI SA/Wa 123/11, ZNSA 2001, Nr 6, s. 169). Będą to zgodnie z regulacją ustawową rozwijającą postanowienia Konstytucji organy jednostek samorządu terytorialnego, samorządowe kolegia odwoławcze i organy administracji rządowej" (B. Banaszak, Konstytucja Rzeczypospolitej Polskiej. Komentarz, Warszawa 2012, nb. 4).

9.2. Trybunał Konstytucyjny stwierdził w jednym z orzeczeń, że z art. 184 zdanie pierwsze Konstytucji „wypływa zasada, iż kontrolę działalności administracji publicznej sprawują: NSA oraz inne sądy administracyjne. Odesłanie przez Konstytucję do ustawy, jeśli chodzi o zakres owej kontroli nie może prowadzić do zniesienia prawa do sądu. W sprawach z zakresu administracji publicznej prawo do sądu realizowane jest poprzez sądownictwo administracyjne. Skoro art. 184 konstytucji stwierdza, że Naczelny Sąd Administracyjny sprawuje kontrolę w zakresie określonym w ustawie, to ustawy określające zakres tej kontroli mają charakter dopełniający treść art. 184 zdanie pierwsze konstytucji, w ten sposób, by zapewnić realizację prawa do sądu - poprzez kognicję sądu administracyjnego. Kontrola określona w art. 184 konstytucji ma na celu zapewnienie prawa do sądu, a więc jest sprawowana jako wymiar sprawiedliwości w stosunku do podmiotów, które tej sprawiedliwości przed sądem dochodzą. Naczelny Sąd Administracyjny jest zatem wyodrębnioną konstytucyjnie częścią władzy sądowniczej, specjalnie powołaną dla tego celu, nie zaś organem kontroli zewnętrznej nad administracją publiczną. Inne są bowiem cele kontroli administracji publicznej. Kontrola ta sprawowana jest wyłącznie z punktu widzenia interesu publicznego, polegającego na zapewnieniu legalnego i celowego działania tej administracji w imię dobra wspólnego. Jeśli zaś chodzi o kontrolę sądową, to jej podstawowym celem jest sprawowanie wymiaru sprawiedliwości. Chodzi tu przede wszystkim o ochronę praw i wolności jednostki (podmiotów prawa), choć i te inne cele są przez sądy administracyjne brane pod uwagę. Takie rozumienie ustrojowej pozycji sądów administracyjnych jest zgodne także z brzmieniem art. 14 ust. 1 Międzynarodowego paktu praw obywatelskich i politycznych (Dz.U. z 1977 r., Nr 38, poz. 167) oraz art. 6 ust. 1 Konwencji o Ochronie Praw Człowieka i Podstawowych Wolności (Dz.U. z 1993 r., Nr 61, poz. 284; zm.: uzup. 1995 r., Nr 36, poz. 175, Nr 95, poz. 176; Nr 36, poz. 177)" (wyrok TK z 14 czerwca 1999 r., sygn. akt K 11/98).

Szeroko na temat odpowiedniego ukształtowania właściwości rzeczowej sądów na tle art. 184 Konstytucji Trybunał Konstytucyjny wypowiedział się w uzasadnieniu wyroku 19 października 2010 r., sygn. akt P 10/10. Stwierdził mianowicie: „Zgodnie z art. 184 Konstytucji »Naczelny Sąd Administracyjny oraz 
inne sądy administracyjne sprawują, w zakresie określonym w ustawie, kontrolę działalności administracji publicznej. Kontrola ta obejmuje również orzekanie o zgodności z ustawami uchwał organów samorządu terytorialnego i aktów normatywnych terenowych organów administracji rządowej«.

Treścią tego przepisu jest wskazanie "podstawowych elementów struktury sądownictwa administracyjnego oraz zakresu właściwości sądów administracyjnych« (L. Garlicki, Uwagi do art. 184, [w:] Konstytucja Rzeczypospolitej Polskiej. Komentarz, red. L. Garlicki, t. IV, Warszawa 2005, s. 3). Zarzuty sądu pytającego odnoszą się do problematyki należącej wyłącznie do tej drugiej sfery, a mianowicie właściwości rzeczowej sądów administracyjnych (kwestie właściwości instancyjnej i miejscowej zostały pominięte).

Trybunał Konstytucyjny dotychczas kilka razy wypowiadał się na temat odpowiedniego ukształtowania właściwości rzeczowej sądów. Zdaniem składu orzekającego w niniejszej sprawie, można mówić o ukształtowaniu się w tym zakresie jednolitej linii orzecznictwa, przyznającej ustawodawcy prawo i obowiązek wyboru sądu odpowiedzialnego za rozstrzygnięcie danej sprawy. Podkreślano przy tym, że ustawodawca, podejmując decyzję w tym zakresie, powinien kierować się m.in. następującymi względami:

- rodzajem« (por. wyroki z: 9 listopada 1999 r., sygn. K 28/98, OTK ZU nr 7/1999, poz. 156; 31 marca 2008 r., sygn. SK 75/06, OTK ZU nr 2/A/2008, poz. 30; 4 lipca 2002 r., sygn. P 12/01, OTK ZU nr 4/A/2002, poz. 50 oraz postanowienie z 8 marca 2000 r., sygn. K 32/98, OTK ZU nr 2/2000, poz. 64) albo »charakterem « sprawy (por. powołany wyrok o sygn. P 12/01 oraz wyrok z 10 maja 2000 r., sygn. K 21/99, OTK ZU nr 4/2000, poz. 109),

- charakterystyką ustrojową danego typu sądu: »sądowa kontrola danej kategorii spraw powinna zostać powierzona sądowi, który jest najlepiej przygotowany do jej rozpoznania - czy to ze względu na swą specjalizację, czy też miejsce w strukturze sądownictwa« (wyrok z 10 czerwca 2008 r., sygn. SK 17/07, OTK ZU nr 5/A/2008, poz. 78);

- procedurą stosowaną przez konkretny rodzaj sądu: »Konstytucja nakazuje ukształtować właściwość poszczególnych sądów tak, by rodzaj rozpatrywanych przez nie spraw był adekwatny do stosowanej procedury« (powołany wyrok o sygn. SK 17/07);

- koniecznością zapewnienia, aby wszystkie sprawy w znaczeniu konstytucyjnym były objęte kontrolą sądową, przy czym w razie "milczenia ustawodawcy» należy uznać dopuszczalność rozpoznania sprawy przez sąd powszechny (por. wyrok z 10 lipca 2000 r., sygn. SK 12/99, OTK ZU nr 5/2000, poz. 143, odwołujący się do wyroku z 9 czerwca 1998 r., sygn. K 28/97, OTK ZU nr 4/1998, poz. 50: "gwarancja prawa do sądu oznacza, że ustawodawcy zwykłemu pozostaje jedynie swoboda wyboru właściwej drogi sądowej: przed sądem powszechnym lub administracyjnym (...) W braku wskazania, iż w konkretnej sprawie, z którą zainteresowany zwrócił się do sądu powszechnego, kompetentny jest inny sąd - 
sąd powszechny powinien sprawę rozpoznać merytorycznie. Tak należy rozumieć konsekwencje konstytucyjnego domniemania ustanowionego $\mathrm{w}$ art. 177 ustawy zasadniczej«; teza powtórzona m.in. w wyroku z 9 grudnia 2003 r., sygn. P 9/02, OTK ZU nr 9/A/2003, poz. 100 i postanowieniu z 14 listopada 2007 r., sygn. SK 53/06, OTK ZU nr 10/A/2007, poz. 139).

Jeżeli zaś chodzi o ocenę podziału właściwości między sądy powszechne (zwłaszcza cywilne) i administracyjne, to Trybunał Konstytucyjny podkreślał m.in., że:

- treść konstytucyjnego prawa do sądu nie może być utożsamiana z 'prawem do sądu powszechnego' " (postanowienie z 14 stycznia 2003 r., sygn. Ts 165/01, OTK ZU nr 1/B/2003, poz. 17);

- nie można [...] z Konstytucji wyprowadzać, ani na podstawie jej art. 45 formułować, prawa podmiotowego do rozpoznania sprawy określonego rodzaju przez sąd administracyjny« (powołane postanowienie o sygn. SK 53/06);

- za sprzeczne z konstytucją należy uznać stosowanie przez sądy swoistego automatyzmu: jeśli źródłem powstałego stosunku prawnego jest decyzja administracyjna (akt administracyjny), to stosunek ten nie może mieć charakteru cywilnoprawnego i - w konsekwencji - droga sądowa [do sądu powszechnego] jest niedopuszczalna" (wspomniane wyroki o sygn. SK 12/99 i P 12/01; por. także problem »wielostopniowości« orzeczeń administracyjnych i cywilnych w sprawach dotyczących nieruchomości przejętych przez Skarb Państwa na podstawie dekretu Polskiego Komitetu Wyzwolenia Narodowego z dnia 6 września 1944 r. o przeprowadzeniu reformy rolnej, Dz. U. z $1945 \mathrm{r}$. Nr 3, poz. 13, ze zm. - postanowienie z 1 marca 2010 r., sygn. P 107/08, OTK ZU nr 3/A/2010, poz. 27);

- zasada, w myśl której sprawy administracyjne mieszczą się w zakresie kognicji Naczelnego Sądu Administracyjnego ma charakter zasady konstytucyjnej, określonej w art. 184 Konstytucji RP. Z istoty więc rzeczy musi to rzutować na interpretację gwarantowanego w art. 45 ust. 1 prawa do 'właściwego sądu'« (postanowienie z 23 stycznia 2002 r., sygn. Ts 77/01, OTK ZU nr 1/B/2002, poz. 68);

- zadanie sprawowania kontroli działalności administracji publicznej sądy administracyjne wykonują ' $w$ zakresie określonym $w$ ustawie', a więc ustawodawca może $w$ uzasadnionych przypadkach przekazać sprawowanie wymiaru sprawiedliwości w tym zakresie sądom powszechnym« (postanowienie z 9 maja 2000 r., sygn. SK 15/98, OTK ZU nr 4/2000, poz. 113).

W kwestii podziału kompetencji między sądy powszechne i sądy administracyjne wypowiadała się także doktryna, w której najwięcej sporów budziła możliwość poszerzania właściwości sądów administracyjnych o sprawy niebędące »kontrolą działalności administracji publicznej«. Problem ten był rozważany nie tylko na tle art. 177 i art. 184 Konstytucji, ale także - zwłaszcza w literaturze z zakresu prawa administracyjnego - art. $3 \$ 3$ p.p.s.a. [ustawa z 30 sierpnia 
2002 r. - Prawo o postępowaniu przed sądami administracyjnymi, t.j. Dz.U. 2017, poz. 1369, ze zm. - uzupełnienie J.P.] (»Sądy administracyjne orzekają także w sprawach, w których przepisy ustaw szczególnych przewidują sądową kontrolę, i stosują środki określone w tych przepisach«). Stanowiska doktryny można umownie podzielić na trzy grupy.

Do pierwszej należy zaliczyć opracowania uznające generalną dopuszczalność powierzania sądom administracyjnym innych spraw niż wymienione wprost w art. 184 Konstytucji ze względu na przysługującą ustawodawcy swobodę kształtowania właściwości sądów, wynikającą z art. 176 ust. 2 Konstytucji. Zawsze zawierają one zastrzeżenie, że tego typu rozwiązania powinny mieć charakter wyjątkowy, bo mogą prowadzić do zawężenia prawa do sądu i zniekształcenia konstytucyjnych zasad podziału właściwości między sądy powszechne i sądy administracyjne (por. L. Garlicki, op. cit., s. 7-8; M. Jaśkowska, Właściwość sądów administracyjnych (zagadnienia wybrane), [w:] Koncepcja systemu prawa administracyjnego, red. J. Zimmermann, Warszawa 2007, s. 568-569).

Do drugiej (dominującej) należą stanowiska koncyliacyjne, wskazujące, że art. $3 \$ 3$ p.p.s.a. w świetle art. 184 Konstytucji wprawdzie upoważnia do poszerzenia kognicji sądów administracyjnych w drodze ustaw szczególnych, ale tylko w bardzo wąskim zakresie. Odsyła on wyłącznie do tych przepisów szczególnych, które przewidują sądową kontrolę administracji publicznej (por. R. Hauser, A. Kabat, Właściwość sądów administracyjnych, „Ruch Prawniczy, Ekonomiczny i Socjologiczny" nr 2/2004, s. 28). W związku z tym kategorycznie wykluczano możliwość orzekania przez sądy administracyjne w sprawach typowo cywilnych (por. np. T. Ereciński, J. Gudowski, J. Iwulski, Komentarz do prawa o ustroju sqdów i ustawy o KRS, Warszawa 2002, s. 24; B. Banaszak, Konstytucja Rzeczypospolitej Polskiej. Komentarz, Warszawa 2009, s. 813), a równocześnie dopuszczano możliwość orzekania w niektórych sprawach wynikających z działalności administracji publicznej przez sądy powszechne (w zależności od tego, czy postępowanie sądowe ma polegać na kontroli działalności administracji, czy na rozpoznaniu sprawy przekazanej sądowi do ostatecznego załatwienia - por. R. Hauser, Nieporozumienia wokół charakteru orzeczeń sądów administracyjnych, [w:] Ratio est anima legis. Księga jubileuszowa ku czci Profesora Janusza Trzcińskiego, Warszawa 2007, s. 237; R. Hauser, A. Kabat, op. cit., s. 25-26).

Do trzeciej należałoby zaliczyć poglądy o niezgodności art. $3 \$ 3$ p.p.s.a. $\mathrm{z}$ art. 184 Konstytucji ze względu na zawarte $\mathrm{w}$ tym przepisie upoważnienie do pozakonstytucyjnego poszerzenia kognicji sądów administracyjnych (por. T. Woś, H. Knysiak-Molczyk, M. Romańska, Postępowanie sq̨dowoadministracyjne, Warszawa 2004, s. 27; wątpliwości w tym zakresie wyrażono także w publikacji W. Chróścielewski, J.P. Tarno, Postępowanie administracyjne i postępowanie przed sądami administracyjnymi, Warszawa 2009, s. 364-365).

Kwestia ustalenia granic właściwości sądów administracyjnych i sądów powszechnych była również rozważana na gruncie konkretnych rozwiązań doty- 
czących kognicji sądów administracyjnych w sprawach dotyczących stosunku pracy, uchwał samorządów zawodowych czy prawa prasowego. Jako - negatywnie oceniany - przykład regulacji ewidentnie wykraczającej poza kontrolę administracji publicznej i ingerującej w relacje między podmiotami prawa cywilnego wskazywano skargę do sądu administracyjnego na odmowę udzielenia prasie informacji przez przedsiębiorców i inne podmioty prywatne (por. np. P. Chróścielewski, J.P. Tarno, op. cit., s. 364-365; M. Jaśkowska, op. cit., s. 567)" (wyrok TK z 19 października 2010 r., sygn. akt P 10/10).

\section{- 10. Artykuł 186 ust. 1 Konstytucji}

Artykuł 186 ust. 1 Konstytucji stanowi: „Krajowa Rada Sądownictwa stoi na straży niezależności sądów i niezawisłości sędziów".

10.1. Zgodnie z poglądem doktryny, „ustrojodawca powierzył KRS szczególną rolę. Ma ona bowiem stać na straży niezależności sądów i niezawisłości sędziów [...]. Jej rola ma zatem fundamentalne znacznie z perspektywy zasad ustrojowych, albowiem KRS ma przez to niejako gwarantować prawidłowe egzekwowanie zasady trójpodziału władzy wyrażonej w art. 10 Konstytucji RP, zwłaszcza w relacjach innych władz do władzy sądowniczej. Ponadto stanie na straży niezależności sądów i niezawisłości sędziów ma także zabezpieczać możliwość prawidłowej realizacji prawa do sądu gwarantowanego każdemu w art. 45 Konstytucji RP. Tym samym KRS, realizując zadanie powierzone jej w art. 186 ust. 1 Konstytucji RP, przyczynia się pośrednio do zachowania zasady trójpodziału władzy oraz gwarantuje możliwość zrealizowania jednego z najważniejszych praw człowieka gwarantowanych w Konstytucji RP, jakim jest prawo do sądu. Należy zauważyć, że stanie na straży niezależności sądów i niezawisłości sędziów dotyczy sądów powszechnych, administracyjnych, wojskowych oraz SN i sędziów pracujących $w$ tych sądach, nie obejmuje natomiast TK oraz TS oraz sędziów tych trybunałów (wyr. TK z 9.12.2015 r., K 35/15, Legalis)" (K. Szczucki, Art. 186 [w:] Konstytucja RP, t. II, Komentarz. Art. 87-243, red. M. Safjan, L. Bosek, Warszawa 2016, nb. 10).

10.2. Wypowiadając się na temat kompetencji Krajowej Rady Sądownictwa, Trybunał Konstytucyjny stwierdził, że: „Krajowa Rada Sądownictwa jest konstytucyjnym, kolegialnym organem państwa, a jej zadania statuują ją w bezpośredniej bliskości władzy sądowniczej, co wynika z systematyki Konstytucji, konstytucyjnie określonego składu Rady i jej kompetencji. [...] Trybunał Konstytucyjny w wyroku z 18 lipca 2007 r., sygn. K 25/07 (OTK ZU nr 7/A/2007, poz. 80), podkreślił, że Rada - jak żaden inny konstytucyjny organ państwa - jest powołana do ochrony niezależności sądów i niezawisłości sędziów. Wskazał, że systematyka Konstytucji nakazuje, aby uprawnienia Krajowej Rady Sądownictwa były traktowane całościowo, zaś kwestia stania na straży nie ogranicza się jedynie do monopolu w zakresie opiniowania nominacji sędziowskich czy też projektów przepisów w zakresie określonym przez art. 186 ust. 1 Konstytucji, ale również, 
w razie uznania przez Radę takiej konieczności, do skorzystania z uprawnienia określonego w art. 186 ust. 2 Konstytucji, czyli wystąpienia do Trybunału.

W wyroku z 28 listopada 2007 r., sygn. K 39/07 (OTK ZU nr 10/A/2007, poz. 129) Trybunał Konstytucyjny stwierdził m.in. że Krajowa Rada Sądownictwa jako organ konstytucyjny »stoi na straży niezależności sądów i niezawisłości sędziów«, a emanacją jej ustrojowej pozycji jest wskazana expressis verbis zdolność inicjowania w takich sprawach abstrakcyjnej kontroli konstytucyjnej ustaw dotykających niezależności sądów i niezawisłości sędziów. W tych sprawach KRS ma dalej idącą zdolność wnioskowania o kontrolę konstytucyjną, wynikającą z konstytucyjnej pozycji KRS. Skoro kompetencje KRS w kwestiach dotyczących niezależności sądów i niezawisłości sędziów mają konstytucyjne zakotwiczenie, to ustawodawca zwykły ma prawo jedynie w konstytucyjnych granicach je doprecyzowywać. Trybunał w wyżej powołanym wyroku o sygn. K 39/07, stwierdził, iż »rozumując zatem a rubrica z treści art. 186 Konstytucji, należy uznać, że pojęcie 'straży', o której mowa w art. 186 ust. 1 Konstytucji, obejmuje czuwanie nad brakiem zagrożeń dla niezależności sądów i niezawisłości sędziów w systemie prawnym «.

Nie jest to tylko stanowisko Trybunału. Warto w tym miejscu przywołać poglądy przedstawione w trakcie prac Komisji Konstytucyjnej Zgromadzenia Narodowego, przy redagowaniu art. 186 Konstytucji, konstytuującego KRS. Podczas posiedzenia podkomisji redakcyjnej, zagadnień ogólnych i przepisów wprowadzających Konstytucję (18, 19 i 20 stycznia 1995 r., Biuletyn KKZN nr XI, s. 325-327), stwierdzono m.in., że troska o niezależność sądów i niezawisłość sędziów w stosunku do innych władz wymaga podkreślenia w tekście Konstytucji, a podkreśleniem tego obowiązku KRS w założeniu ustrojodawcy jest właśnie »stanie na straży« (głosy przedstawiciela Prezydenta PR prof. A. Rzeplińskiego i eksperta Komisji prof. P. Winczorka oraz członków Komisji senatora H. Rota i posła J. Ciemniewskiego). Tezy te znalazły potwierdzenie w czasie obrad Komisji Konstytucyjnej 27 września 1995 r. oraz 20 sierpnia 1996 r. (Biuletyny KKZN Nr XXV, s. 71-72 oraz nr XXXVIII, s. 109-110) i w konsekwencji w tekście uchwalonej Konstytucji” (wyrok TK z 16 kwietnia 2008 r., sygn. akt K 40/07).

W jednym z najnowszych orzeczeń Trybunał Konstytucyjny w odniesieniu do art. 186 Konstytucji stwierdził, że przepis ten „określa ogólne zadanie Krajowej Rady Sądownictwa, jakim jest stanie na straży niezawisłości sędziów i niezależności sądów, ale - poza przyznaniem KRS prawa inicjowania postępowań przed Trybunałem Konstytucyjnym - przepis ten nie wskazuje ani środków, ani procedur służących realizacji tego zadania. Co do zasady pozostawione to zostało ustawodawcy zwykłemu, a wyjątek w tym względzie stanowi art. 179 Konstytucji, zgodnie z którym sędziowie są powoływani przez Prezydenta Rzeczypospolitej na wniosek KRS (zob. wyrok TK o sygn. P 16/04).

Trybunał Konstytucyjny podkreślał, że Rada jest powołana do ochrony niezależności sądów i niezawisłości sędziów. Realizuje to za pomocą posiadanych 
instrumentów prawnych. Z kolei systematyka Konstytucji wymaga, by uprawnienia KRS były traktowane całościowo. Dlatego zadanie stania na straży nie ogranicza się jedynie do monopolu w zakresie opiniowania nominacji sędziowskich czy też projektów przepisów w zakresie określonym przez art. 186 ust. 1 Konstytucji, ale również, w razie uznania przez Radę takiej konieczności, polega na skorzystaniu z uprawnienia określonego w art. 186 ust. 2 Konstytucji, czyli wystąpieniu z wnioskiem o zbadanie konstytucyjności określonych przepisów prawa do Trybunału (zob. wyroki TK o sygn. K 25/07 i o sygn. K 40/07)" (wyrok TK z 20 czerwca 2017 r., sygn. akt K 5/17).

\section{- 11. Artykuł 187 ust. 1 pkt 2 i art. 187 ust. 4 Konstytucji}

Artykuł 187 ust. 1 pkt 2 Konstytucji stanowi: „1. Krajowa Rada Sądownictwa składa się z: [...] 2) piętnastu członków wybranych spośród sędziów Sądu Najwyższego, sądów powszechnych, sądów administracyjnych i sądów wojskowych”.

Artykuł 187 ust. 4 Konstytucji stanowi: „Ustrój, zakres działania i tryb pracy Krajowej Rady Sądownictwa oraz sposób wyboru jej członków określa ustawa”.

11.1. W art. 187 ust. 1 Konstytucji określony został skład Krajowej Rady Sądownictwa. Do pierwszej grupy członków KRS należą osoby wchodzące w jej skład z urzędu, a mianowicie zgodnie z brzmieniem art. 187 ust. 1 pkt 1 Konstytucji Krajowa Rada Sądownictwa składa się z: „1) Pierwszego Prezesa Sądu Najwyższego, Ministra Sprawiedliwości, Prezesa Naczelnego Sądu Administracyjnego i osoby powołanej przez Prezydenta Rzeczypospolitej”. Drugą grupę stanowią wybrani sędziowie, zgodnie z brzmieniem art. 187 ust. 1 pkt 2 Konstytucji: „2) piętnastu członków wybranych spośród sędziów Sądu Najwyższego, sądów powszechnych, sądów administracyjnych i sądów wojskowych”. Trzecią grupę stanowią wybrani posłowie i senatorowie, co normuje art. 187 ust. 1 pkt 3 Konstytucji: „3) czterech członków wybranych przez Sejm spośród posłów oraz dwóch członków wybranych przez Senat spośród senatorów”.

W doktrynie przekonująco podnosi się, że na gruncie art. 187 ust. 1 Konstytucji RP rodzi się wątpliwość w odniesieniu do sposobu wyboru piętnastu członków spośród sędziów SN, sądów powszechnych, sądów administracyjnych i sądów wojkkowych: „W literaturze oraz orzecznictwie toczy się dyskusja, w której niektórzy podnoszą zarzut nadreprezentacji sędziów reprezentujących wyższe szczeble instancyjne względem pozostałych. Sąd Najwyższy zajmuje jednolite stanowisko, w którym wskazuje, że art. 187 ust. 1 Konstytucji RP nie zawiera szczegółowych zasad wyboru sędziów do KRS, a więc nie gwarantuje każdemu sędziemu równego prawa głosu. Konstytucja pozostawia w tym zakresie swobodę ustawodawcy (wyr. SN z 2.4.2014 r., III KRS 8/14, niepubl.; zob. też wyr. SN z: 17.8.2010 r., III KRS 10/10 Legalis; 15.3.2012 r., III KRS 1/11, OSNAPiUS 2012, Nr 9-10, poz. 131; por. też B. Kostyk, Niekonstytucyjność trybu wyboru [Niekonstytucyjność trybu wyboru części członków Krajowej Rady Sądownictwa, „Iustitia” 2015, nr 2 - uzupełnienie J.P.], s. 88). Ten sposób rozumowania SN krytyko- 
wany jest przez niektórych przedstawicieli środowiska sędziowskiego. Wskazuje się, że każdy sędzia w tym samym stopniu jest reprezentantem władzy sądowniczej, zaś wszelkie różnice są efektem przyjętej struktury sądów, a nie skutkiem zróżnicowania konstytucyjnego statusu sędziów (B. Kostyk, Niekonstytucyjność trybu wyboru, s. 89). Przywołany autor wskazuje, że: »Konstytucja nie preferuje w wyborach do KRS sędziów żadnego rodzaju sądów. Tymczasem SN stwierdził, że 'przepis art. 187 ust. 1 Konstytucji nie gwarantuje każdemu sędziemu równego prawa głosu ani nie zawiera żadnych sugestii w tym kierunku'. Z tym poglądem nie sposób się zgodzić. Skoro Konstytucja nie ogranicza w żaden sposób praw wyborczych żadnego sędziego, to wykładnia językowa nakazuje uznać, że wszyscy oni mają ten sam status wyborczy nadany przez art. 187 ust. 1 pkt 2 Konstytucji RP. Podstawowy błąd w rozumowaniu SN, powielony za ustawodawcą zwykłym, polega na rozróżnieniu statusu wyborczego sędziów, pomimo, że cytowany wyżej przepis konstytucyjny na to nie zezwala (lege non distinguente nec nostrum est distinguere) «(B. Kostyk, Niekonstytucyjność trybu wyboru, s. 89). Autor podnosi także argument z niezawisłości sędziowskiej: »Sąd Najwyższy nie przeanalizował skutków swego orzeczenia w kontekście sędziowskiej zasady niezawisłości (art. 178 ust. 1 Konstytucji RP). Wydaje się, że częścią składową (jedną z wielu) niezawisłości sędziego są jego niczym nieograniczone prawa wyborcze. Jak bowiem przekonać obywatela, że sędzia sądu okręgowego jest tak samo niezawisły jak sędzia SN, skoro pierwszy z nich funkcjonuje w przestrzeni wyborów kurialnych stanowiących ustrojowy relikt, a drugi korzysta $\mathrm{z}$ wyborczej zasady równości w kreowaniu tego samego organu konstytucyjnego? Niezawisłość sędziego oznacza także brak jego uzależnienia od innych sędziów również w sferze samorządowej. Nie jest to możliwe do osiągnięcia na płaszczyźnie wyborów kurialnych. Między innymi tym uzależnieniem organizacyjnym należy tłumaczyć zjawisko orzekania 'pod drugą instancję. Ograniczenie wielu negatywnych zjawisk występujących w sądownictwie jest możliwe tylko przy zachowaniu wyborczej zasady równości w sferze samorządowej, kreującej również członków KRS « (B. Kostyk, Niekonstytucyjność trybu wyboru, s. 90)" (K. Szczucki, Art. 187 [w:] Konstytucja RP, t. II, Komentarz. Art. 87-243, red. M. Safjan, L. Bosek, Warszawa 2016, nb. 7).

11.2. Artykuł 187 ust. 4 Konstytucji przekazuje ustawodawcy kompetencję do określenia ustroju, zakresu działania, trybu pracy oraz sposobu wyboru członków Krajowej Rady Sądownictwa: „Ustrój, zakres działania i tryb pracy Krajowej Rady Sądownictwa oraz sposób wyboru jej członków określa ustawa”.

Przepis art. 187 ust. 4 Konstytucji daje ustawodawcy bardzo szeroki zakres swobody regulacji w ustawie zarówno ustroju, zakresu działania, trybu pracy Krajowej Rady Sądownictwa, jak i sposobu wyboru jej członków. Ustawodawca nie może jednak w sposób dowolny regulować tych materii w ustawie, lecz powinien respektować zasady konstytucyjne, m.in. zasadę równości, wyrażoną w art. 32 Konstytucji. 
Zgodnie z poglądem Trybunału Konstytucyjnego, z istoty KRS wynika, że „wyraża ona na zewnątrz swą wolę jako jednolity organ (uchwała KRS), ale sposób dochodzenia do uchwały, czy procedura podejmowania decyzji, będzie określona ustawą, gdyż wynika to wprost $\mathrm{z}$ art. 187 ust. 4 Konstytucji. Trybunał dostrzega tu konstytucyjnie umocowaną znaczącą rolę ustawodawcy. Zakres swobody jego działania wskazany w art. 187 ust. 4 Konstytucji jest szeroki. Obejmuje ustrój, zakres działania i tryb pracy Krajowej Rady Sądownictwa oraz sposób wyboru jej członków, co powoduje, że wśród przepisów konstytucyjnych zawierających odesłania do uregulowania określonych zagadnień dotyczących konstytucyjnych organów państwa w ustawie - regulacja dotycząca KRS daje ustawodawcy dużą swobodę. To znaczy, że ustawodawca może uregulować więcej zagadnień dotyczących KRS niż w odniesieniu do innych organów wskazanych w Konstytucji. Dla porównania, w wypadku Trybunału Konstytucyjnego i Trybunału Stanu ustawa ma określać ich organizację oraz tryb postępowania przed danym trybunałem (art. 197 i art. 201 Konstytucji). Skład tych organów i sposób ich powoływania jest uregulowany w Konstytucji. Z kolei, zgodnie z art. 207 Konstytucji, organizację i tryb działania Najwyższej Izby Kontroli określa ustawa. W art. 227 ust. 7 Konstytucji ustrojodawca przesądził zaś o tym, że organizację i zasady działania Narodowego Banku Polskiego oraz szczegółowe zasady powoływania i odwoływania jego organów określa ustawa.

Wskazane przykłady pokazują, że nie można jednakowo podchodzić do oceny realizacji przez ustawodawcę konstytucyjnej delegacji dotyczącej uregulowania określonych zagadnień dotyczących danego organu w ustawie. Do każdego z tych organów należy podchodzić w sposób autonomiczny" (wyrok TK z 20 czerwca 2017 r., sygn. akt K 5/17).

\section{Analiza zgodności}

- 1. Kwestia zgodności art. 9a ust. 1 uKRS z art. 186 ust. 1 oraz z art. 187 ust. 1 pkt 2 i ust. 4 w związku z art. 2, art. 10 ust. 1 i art. 173 Konstytucji

Zaskarżone $\mathrm{w}$ punkcie pierwszym petitum wniosku przepisy weszły w życie w wyniku nowelizacji ustawy o KRS, wprowadzonej ustawą z dnia 8 grudnia 2017 r. o zmianie ustawy o Krajowej Radzie Sądownictwa oraz niektórych innych ustaw (Dz. U. 2018, poz. 3). Ich ostateczny kształt - jak zaznacza wnioskodawca - był wynikiem z jednej strony, trwających od pewnego czasu działań ustawodawczych, zaś z drugiej - refleksem poglądów Trybunału Konstytucyjnego dotyczących normatywnej treści art. 187 ust. 1 pkt 2 Konstytucji, przedstawionych w uzasadnieniu wyroku z dnia 20 czerwca 2017 r., sygn. akt K 5/17.

Wnioskodawca określa istotę problemu konstytucyjnego $\mathrm{w}$ odniesieniu do punktu pierwszego petitum wniosku jako potrzebę dokonania oceny, „czy $\mathrm{w}$ świetle normatywnych treści zawartych w powołanych w przedmiotowej spra- 
wie jako wzorce kontroli art. 187 ust. 1 pkt 2 i ust. 4 w zw. z art. 2, art. 10 ust. 1 i art. 173 Konstytucji oraz art. 186 ust. 1 Konstytucji RP dopuszczalne jest unormowanie przewidujące powoływanie sędziów wchodzących w skład KRS przez inny podmiot niż samo środowisko sędziowskie" (wniosek, s. 28).

Tak określony problem konstytucyjny był przedmiotem licznych kontrowersji w doktrynie wyrażonych na etapie prac legislacyjnych nad uchwaleniem ustawy zmieniającej ustawę o KRS, a także po wejściu w życie zaskarżonych przepisów normujących procedurę powoływania sędziów wchodzących w skład KRS przez Sejm.

Przekonanie o konstytucyjnym umocowaniu zasady wybierania sędziów przez sędziów wyraził Trybunał Konstytucyjny w wyroku z 18 lipca 2007 r., sygn. akt K 25/07, w którym Trybunał stwierdził m.in., że: „Konstytucja w art. 187 ust. 1 pkt 2 reguluje bezpośrednio zasadę wybieralności sędziów do KRS, decydując w ten sposób o strukturze osobowej Rady. Wyraźnie określa, że członkami KRS mogą być sędziowie, wybierani przez sędziów”.

Nie można zgodzić się z przytoczonym poglądem Trybunału Konstytucyjnego, jakoby Konstytucja w art. 187 ust. 1 pkt 2 „wyraźnie” określała, że członkami KRS mogą być sędziowie „wybierani przez sędziów”, ponieważ w przepisie tym brak nie tylko wyraźnego określenia tej kwestii, ale brak jej jakiegokolwiek określenia.

W innym fragmencie cytowanego wyroku Trybunał Konstytucyjny stwierdził, że: „Art. 187 ust. 1 Konstytucji stanowi, że skład KRS ma charakter mieszany: łączy przedstawicieli środowiska sędziowskiego (z obligatoryjnym udziałem Prezesów SN i NSA), przedstawicieli władzy wykonawczej (Ministra Sprawiedliwości i osoby powołanej przez Prezydenta RP) oraz po dwóch posłów i senatorów".

Jeśli w argumentacji na rzecz rzekomo wyraźnie określonej zasady wybierania sędziów przez sędziów w art. 187 ust. 1 pkt 2 Konstytucji, zwolennicy takiego poglądu podają z pełną powagą ustalenia Trybunału Konstytucyjnego poczynione w uzasadnieniu wyroku z 18 lipca 2007 r., sygn. akt K 25/07, to z taką samą powagą powinni również traktować stwierdzenie TK w tym samym uzasadnieniu, że z art. 187 ust. 1 Konstytucji jasno wynika, że w skład KRS wchodzi „po dwóch posłów i senatorów".

Słusznie zatem, w przekonaniu Sejmu, Trybunał Konstytucyjny w wyroku z 20 czerwca 2017 r., sygn. akt K 5/17 nie zgodził się ze „stanowiskiem zajętym w wyroku o sygn. K 25/07, że Konstytucja określa, iż członkami KRS mogą być sędziowie wybierani przez sędziów. Art. 187 ust. 1 pkt 2 Konstytucji stanowi jedynie, że osoby te są wybierane spośród sędziów. Ustrojodawca nie wskazał jednak, kto ma wybierać tych sędziów. Zatem z Konstytucji wynika, kto może być wybranym członkiem KRS, ale nie jest określone, jak wybrać sędziów członków KRS do tej Rady. Te kwestie zostały przekazane do uregulowania w ustawie. Nic nie stoi na przeszkodzie, aby sędziów do KRS wybierali sędziowie. Jednak nie można się zgodzić z twierdzeniem, że piastunem czynnego prawa wyborczego 
muszą tu być wyłącznie gremia sędziowskie. O ile art. 187 ust. 1 pkt 3 Konstytucji wyraźnie wskazuje, że do KRS posłowie wybierani przez Sejm, a senatorowie przez Senat, o tyle w stosunku do sędziów członków KRS nie ma w tym zakresie żadnych wytycznych konstytucyjnych. To znaczy, że Konstytucja nie przesądza tego, kto może wybierać w skład KRS sędziów. Z tego względu należy stwierdzić, że w granicach swobody ustawodawczej kwestia ta może być w różny sposób uregulowana.

Polski system prawny dopuszcza sytuację, gdy członkami danego organu władzy publicznej są sędziowie, których w skład tego organu powołuje organ spoza władzy sądowniczej. Jako przykłady należy tu podać Państwową Komisję Wyborczą (dalej: PKW), która nie jest sądem, ale ma skład sędziowski. Członków PKW powołuje Prezydent RP spośród sędziów TK, SN i NSA wskazanych odpowiednio przez Prezesa TK, Pierwszego Prezesa SN i Prezesa NSA. Również okręgowe komisje wyborcze, mimo że nie są sądami, składają się z sędziów i są powoływane przez PKW. I mówi o tym właśnie ustawa, która wskazuje podmiot wyznaczający grono kandydatów (zob. ustawa z dnia 5 stycznia 2011 r. - Kodeks wyborczy, Dz. U. z 2017 r. poz. 15)" (wyrok TK z 20 czerwca 2017 r., sygn. akt K 5/17).

Należy również podkreślić, że art. 253 Traktatu o funkcjonowaniu Unii Europejskiej (Dz. U. 2004, Nr 90, poz. 864/2, ze zm., tekst skonsolidowany: Dz. Urz. UE C 202 z 2016 r., s. 47, dalej: TFUE), regulujący wybór i mianowanie sędziów i rzeczników generalnych Trybunału Sprawiedliwości, przewiduje, że: „[s]ędziowie i rzecznicy generalni Trybunału Sprawiedliwości są wybierani spośród osób o niekwestionowanej niezależności i mających kwalifikacje wymagane w ich państwach do zajmowania najwyższych stanowisk sądowych lub są prawnikami o uznanej kompetencji. Są oni mianowani za wspólnym porozumieniem przez rządy Państw Członkowskich na okres sześciu lat, po konsultacji z komitetem przewidzianym w artykule 255”. Zatem zgodnie z art. 253 TFUE, sędziowie Trybunału Sprawiedliwości Unii Europejskiej są wybierani przez rządy państw członkowskich.

Przekonująca, zdaniem Sejmu, argumentacja na rzecz dopuszczalności unormowania przewidującego powoływanie sędziów wchodzących w skład KRS przez inny podmiot niż samo środowisko sędziowskie została wyartykułowana $\mathrm{w}$ jednej z opinii eksperckich, sformułowanej w toku prac legislacyjnych nad uchwaleniem ustawy zmieniającej ustawę o KRS. W opinii tej stwierdzono, co następuje: „Z porównania kształtu językowego art. 187 ust. 1 pkt 2 Konstytucji ("piętnastu członków wybranych spośród sędziów Sądu Najwyższego, sądów powszechnych, sądów administracyjnych i sądów wojkkowych «) i art. 187 ust. 1 pkt 3 Konstytucji (»czterech członków wybranych przez Sejm spośród posłów oraz dwóch członków wybranych przez Senat spośród senatorów«) jasno wynika, że ustrojodawca w art. 187 ust. 1 pkt 2 Konstytucji świadomie nie posłużył się wyrażeniem "wybranych przez sędziów», aby pozostawić otwartą kwestię 
podmiotu, który będzie dokonywał wyboru sędziów. Gdyby chciał wskazać ten podmiot, zapewne zastosowałby analogiczną metodę, jak w przypadku sformułowania art. 187 ust. 1 pkt 3 Konstytucji. Wówczas przepis art. 187 ust. 1 pkt 2 Konstytucji powinien otrzymać brzmienie: »2) piętnastu członków wybranych przez sędziów spośród sędziów Sądu Najwyższego, sądów powszechnych, sądów administracyjnych i sądów wojskowych «, ale takiego brzmienia nie otrzymał. Zatem na podstawie art. 187 ust. 1 pkt 2 Konstytucji nie można wyprowadzać, ani domniemywać, kompetencji sędziów do dokonywania wyboru sędziów. Kompetencję tę wyraźnie określa obecnie uKRS. Czyni to nie na podstawie art. 187 ust. 1 pkt 2 Konstytucji, lecz na podstawie art. 187 ust. 4 Konstytucji, zgodnie z którym: »Ustrój, zakres działania i tryb pracy Krajowej Rady Sądownictwa oraz sposób wyboru jej członków określa ustawa«. Ponieważ ustrojodawca świadomie pozostawił otwartą kwestię, kto będzie dokonywał wyboru sędziów, inaczej niż w przypadku określenia, kto będzie wybierał posłów i kto będzie wybierał senatorów, ustawodawca ma kompetencję i obowiązek, wynikający z art. 187 ust. 4 Konstytucji, wskazać ten podmiot.

Wobec powyższych argumentów należy stwierdzić, że wprowadzone w projekcie unormowanie, zgodnie z którym Sejm wybiera sędziów-członków Krajowej Rady Sądownictwa, o których mowa w art. 187 ust. 1 pkt 2 Konstytucji, mieści się w ramach swobody ustawodawcy do określenia sposobu wyboru członków Krajowej Rady Sądownictwa, określonej w art. 187 ust. 4 Konstytucji” (J. Potrzeszcz, Opinia prawna w sprawie zgodności z Konstytucja przedstawionego przez Prezydenta Rzeczypospolitej Polskiej projektu ustawy o zmianie ustawy o Krajowej Radzie Sądownictwa oraz niektórych innych ustaw, http://www.sejm. gov.pl/sejm8.nsf/opinieBAS.xsp?nr=2002).

Argumenty krytyków obowiązujących unormowań określających kompetencję Sejmu do wybierania sędziów-członków KRS, które przytacza wnioskodawca, oparte są nie na wykładni językowej, lecz systemowej, funkcjonalnej czy nawet na wnioskowaniu a contrario.

Należy jednak podkreślić, że w przypadku przepisów kompetencyjnych nie można posługiwać się tego rodzaju dyrektywami interpretacyjnymi. Jednoznacznie na ten temat wypowiedział się Trybunał Konstytucyjny, który stwierdził, że: „Nauka prawa konstytucyjnego (jak również teoria państwa i prawa) pojęcie kompetencji wiąże nierozłącznie $\mathrm{z}$ określonym zespołem norm prawnych »wyznaczających sytuację, w których organ państwa w odpowiedni sposób zachowa się, przez co ulegnie w jakimś stopniu zmianie sytuacja prawna innych podmiotów tzn. organów państwa czy ludzi« (J. Trzciński, Pojęcie konstytucyjnego organu państwa... Ossolineum 1974 [Pojęcie konstytucyjnego organu państwa socjalistycznego (na tle Konstytucji PRL), Wrocław 1974 - uzupełnienie J.P.], s. 75. Podobnie Z. Ziembiński, Kompetencja i norma kompetencyjna, „Ruch Prawniczy, Ekonomiczny i Socjologiczny" 1969, z. 4, s. 9). Założenie to znajduje oparcie w konstytucyjnej zasadzie legalności nakazującej oparcie działalności organów 
państwowych wyłącznie na przepisach prawa. Zasada wg. której wszystkie organy władzy i administracji państwowej działają na podstawie przepisów prawa oznacza »konieczność istnienia podstawy prawnej do jakiejkolwiek działalności organu państwa. Organy państwa mogą działać tylko wtedy, gdy jest do tego podstawa prawna [...] tylko w tych wypadkach, gdy mu prawo na to zezwala « (J. Trzciński, j. w., s. 108).

Z. Ziembiński dokonując wykładni tego postanowienia pisze: »Rozumieć to należy w ten sposób, że jakiś człowiek czy zespół osób może dokonywać odpowiednich czynności konwencjonalnych, występując jako organ państwa dopiero wtedy, gdy odpowiednia norma prawna udziela mu do tego kompetencji, nakazując innym podmiotom odpowiednio podporządkować się aktom dokonanym na podstawie tej kompetencji. Czynności konwencjonalne osób nie oparte na udzielonej im jako organowi państwa kompetencji, teoretycznie biorąc 'nie liczą się jako czynności organu państwa, są dotknięte nieważnością« ([Z. Ziembiński] Analiza pojęcia czynu, Warszawa 1972, s. 149).

Przytoczone poglądy nauki odnoszące się do kompetencji organów państwa świadczą o tym, iż były one jednoznaczne na wiele lat przed zmianami konstytucyjnymi. Pogląd, iż organ państwa może działać tylko wtedy, gdy prawo mu na to zezwala stanowi communis opinio nauki prawa konstytucyjnego.

Trybunał Konstytucyjny w swoim orzecznictwie zajmował w sprawie przepisów kompetencyjnych stanowisko zdecydowane, stwierdzając wielokrotnie, iż przepis kompetencyjny: "podlega zawsze ścisłej wykładni literalnej, domniemanie objęcia upoważnieniem materii w nim nie wymienionych w drodze np. wykładni celowościowej nie może wchodzić w rachubę... (orzeczenie K 5/86, zob. też P 2/86, U 6/87, K 1/87, K 1/89, U 3/92, K 11/93).

Zdaniem Trybunału Konstytucyjnego z konstytucyjnej zasady legalności jak również z zasady demokratycznego państwa prawa wynika jednoznaczny wniosek, że w przypadku, gdy normy prawne nie przewidują wyraźnie kompetencji organu państwowego, kompetencji tej nie wolno domniemywać i w oparciu o inną rodzajowo kompetencję przypisywać ustawodawcy zamiaru, którego nie wyraził" (orzeczenie TK z 10 maja 1994 r., sygn. akt W 7/94).

Pomimo że jest powszechnie znana i uznawana dyrektywa wykładni odnosząca się do przepisu kompetencyjnego, zgodnie z którą podlega on „zawsze ścisłej wykładni literalnej, domniemanie objęcia upoważnieniem materii w nim nie wymienionych w drodze np. wykładni celowościowej nie może wchodzić w rachubę", formułowane są w doktrynie alternatywne sposoby wykładni art. 187 ust. 1 pkt 2 Konstytucji, które stoją w oczywistej sprzeczności z tą dyrektywą.

Wnioskodawca przytacza mianowicie pogląd, zgodnie z którym, „przyjęcie, że sędziów-członków KRS może wybierać władza ustawodawcza, jest nie do pogodzenia z Konstytucją RP. W pierwszej kolejności wniosek taki wyprowadza się z systemowego i funkcjonalnego powiązania art. 187 ust. 1 Konstytucji, określającego skład KRS, z art. 10 i art. 173 Konstytucji, które ustanawiają zasady podziału 
i równowagi władz oraz odrębności i niezależności sądów. Jak to przedstawiono, art. 187 ust. 1 Konstytucji przyznaje władzy wykonawczej i władzy ustawodawczej zarówno odpowiednią liczbę przedstawicieli w KRS, jak i przyznaje każdej z tych władz kompetencję do ich powołania. Nie sposób twierdzić, że w przypadku trzeciej władzy Konstytucja RP, określając skład, a co za tym idzie - w znacznym stopniu funkcjonowanie organu konstytucyjnego odpowiedzialnego za niezależność sądów i niezawisłość sędziów, »dyskryminowała « władzę sądowniczą, przyznając jej wprawdzie reprezentantów w KRS, lecz nakazując wybór tych reprezentantów innej władzy - władzy ustawodawczej. Brak wyraźnego wskazania w art. 187 ust. 1 pkt 2 Konstytucji podmiotu, który wybiera sędziów członków KRS, uznać należałoby jedynie za lukę konstrukcyjną, którą, zgodnie z przyjętymi zasadami wykładni przepisów prawa, należy uzupełnić poprzez zastosowanie systemowych i funkcjonalnych metod wykładni” (wniosek, s. 28-29).

W dalszym fragmencie cytowanego poglądu sformułowany został argument, że wymóg podziału i równowagi nie jest spełniony, „jeśli jedna z władz - władza ustawodawcza - oprócz kompetencji do powołania swoich reprezentantów otrzymuje kompetencję wyboru reprezentantów władzy sądowniczej. [...] W ten sposób zachwiana zostaje zrównoważona konstrukcja, w ramach której każdej z władz przypisane jest dwuelementowe uprawnienie: odpowiednia liczba reprezentantów i kompetencja do ich wyboru. Konstrukcja ta wymaga więc, aby władza sądownicza miała, podobnie jak władza ustawodawcza i wykonawcza, nie tylko swoich reprezentantów, ale także kompetencję do ich powołania" (ibidem, s. 29).

Idąc tym tokiem rozumowania można byłoby uzasadniać, że równowaga władz byłaby zachowana, jeśli każda $\mathrm{z}$ władz miałaby kompetencję do wybrania takiej samej liczby reprezentantów. W obecnym stanie prawnym pod tym względem uprzywilejowaną pozycję ma władza sądownicza.

Kolejny argument mający uzasadniać naruszenie wskazanych wzorców konstytucyjnych przez unormowania ustawy o KRS powierzające Sejmowi kompetencję do wybierania sędziów-członków KRS, „wynikać ma z charakteru KRS - organu, który oprócz swojej kluczowej funkcji, jaką jest stanie na straży niezależności sądów i niezawisłości sędziów, ma umożliwiać przewidziane przez Preambułę Konstytucji RP współdziałanie władz. [...] Według tej argumentacji »zapewniony przez Konstytucję RP udział władzy ustawodawczej i wykonawczej w składzie KRS, a tym samym dopuszczenie tych władz do współdecydowania o procesie opiniowania i powoływania sędziów, należy traktować w kategoriach wyjątku od ogólnej zasady odrębności i niezależności, przewidzianej w art. 173 Konstytucji RP. Jako wyjątek, udział ten nie powinien podlegać rozszerzaniu, zgodnie z paremią (sic!) exceptiones non sunt extendendae. Tymczasem przyznanie władzy ustawodawczej kompetencji do wybrania do KRS nie tylko jej reprezentantów, ale także reprezentantów władzy sądowniczej, w sposób oczywisty rozszerza wyjątkowo przyznany Konstytucją RP innym władzom udział we 
współdecydowaniu o sprawach kluczowych dla władzy sądowniczej«" (ibidem, s. 30).

Odnosząc się do tak sformułowanego argumentu, należy zwrócić uwagę na przyjęcie w nim nietrafnego założenia, jakoby współdecydowanie o procesie opiniowania i powoływania sędziów przez władzę ustawodawczą było wyjątkiem od ogólnej zasady odrębności i niezależności, przewidzianej w art. 173 Konstytucji. Idąc tym tokiem myślenia, należałoby przyjąć, że zasadą jest odrębność i niezależność sądów i trybunałów od innych władz, a wyjątkiem, czyli odstępstwem, od tej zasady współdecydowanie o procesie opiniowania i powoływania sędziów przez władzę ustawodawczą. Wobec tego rzeczone współdecydowanie stanowiłoby zagrożenie (czy przekreślenie?) zasady odrębności i niezależności sądów i trybunałów od innych władz. W takim wypadku Konstytucja zawierałaby przepisy wzajemnie sprzeczne. Zakładając jednak, że ustawodawca konstytucyjny jest racjonalny, nie można dokonywać wykładni przepisów konstytucyjnych w taki sposób, aby prowadziło to do absurdalnych rezultatów. Idąc dalej tokiem myślenia przyjętym $\mathrm{w}$ analizowanym argumencie, należałoby stwierdzić, że racjonalny prawodawca nie mógłby również wprowadzić do Konstytucji art. 194 ust. 1 zdanie pierwsze, zgodnie z którym: „Trybunał Konstytucyjny składa się z 15 sędziów, wybieranych indywidualnie przez Sejm na 9 lat spośród osób wyróżniających się wiedzą prawniczą". Nie mógłby jednocześnie wprowadzić art. 195 ust. 1, zgodnie z którym: „Sędziowie Trybunału Konstytucyjnego w sprawowaniu swojego urzędu są niezawiśli i podlegają tylko Konstytucji”.

Skoro jednak wskazane przepisy znalazły miejsce w Konstytucji, to niewątpliwie musi to świadczyć o tym, że racjonalny prawodawca nie dostrzegał zagrożeń dla odrębności i niezależności, a także niezawisłości sędziów, w tym sędziów Trybunału Konstytucyjnego, w samym fakcie ich wyboru przez Sejm.

Trzeci przytoczony przez wnioskodawcę argument „za niedopuszczalnością powierzenia wyboru sędziów-członków KRS Sejmowi wynikać ma z gramatycznej i systemowej konstrukcji art. 187 Konstytucji RP, uzupełnionej przez rozumowanie zgodne $\mathrm{z}$ modelem argumentum a contrario oraz argumentacją $\mathrm{z}$ racjonalności językowej ustawodawcy konstytucyjnego. Podnosi się bowiem, że «skoro [...] brzmienie art. 187 ust. 1 pkt 1 i 3 zawiera wyraźne wskazanie podmiotów upoważnionych do powołania członków KRS (tj. wskazanie Prezydenta w pkt 1 oraz Sejmu i Senatu w pkt 3), to należy przyjąć, że racjonalny ustawodawca konstytucyjny także w punkcie 2 wskazałby podmiot upoważniony do powołania sędziów-członków KRS. Ponieważ tego nie zrobił, należy uzupełnić tę lukę przez wskazaną powyżej wykładnię systemową, uwzględniającą powiązania pomiędzy art. $187 \mathrm{i}$ art. 10 Konstytucji, oraz funkcjonalną, uwzględniającą powiązania pomiędzy art. 187 a art. 187 i 173 Konstytucji, wskazującymi na rolę KRS. Przyjęcie, że właściwym uzupełnieniem tej luki jest powierzenie kompetencji do powołania sędziów-członków KRS Sejmowi stoi w sprzeczności z faktem, że ustawodawca konstytucyjny tam, gdzie to zamierzył, wyraźnie tę kompetencję 
Sejmowi przyznał (art. 187 ust. 1 pkt 3). Rozumując a contrario, skoro w art. 187 ust. 1 pkt 3 kompetencja do wyboru określonej liczby członków KRS została Sejmowi przyznana expressis verbis, nie można przyjąć, że jest ona dopuszczalna także w art. 187 ust. 1 pkt 2. Gdyby tak było, racjonalny językowo ustawodawca konstytucyjny przyznałby tę kompetencję Sejmowi wprost «” (ibidem, s. 30-31).

W odniesieniu do tego argumentu, powołującego się na racjonalność językową ustawodawcy konstytucyjnego, można zgodzić się, że tam, gdzie to zamierzył, wyraźnie kompetencję do powołania sędziów-członków KRS Sejmowi przyznał, ale nie można uznać za trafne posłużenie się rozumowaniem a contrario, aby w ten sposób uzupełnić lukę w miejscu, w którym brak przyznania kompetencji jakiemukolwiek podmiotowi do wyboru sędziów-członków KRS i przyznać tę kompetencję sędziom. Jak to już wcześniej zostało podkreślone, przepisy kompetencyjne podlegają zawsze ścisłej wykładni literalnej.

Wobec pozostawienia przez ustawodawcę konstytucyjnego nierozstrzygniętej kwestii powierzenia kompetencji do wybierania sędziów-członków KRS, jedynym racjonalnym wyjaśnieniem tego faktu jest przyjęcie, że świadomie pozostawił tę kwestię do uregulowania w ustawie, zgodnie z art. 187 ust. 4 Konstytucji: „Ustrój, zakres działania i tryb pracy Krajowej Rady Sądownictwa oraz sposób wyboru jej członków określa ustawa”. Racjonalny prawodawca, znający reguły wykładni przepisów kompetencyjnych, nie mógłby wprowadzić do Konstytucji art. 187 ust. 1 pkt 2 z taką intencją, aby kompetencja sędziów musiała być wyprowadzana w drodze skomplikowanych operacji myślowych, angażujących wszelkie możliwe dyrektywy wykładni, z wyłączeniem wykładni językowej.

Konkludując Sejm jednoznacznie twierdząco odpowiada na postawione przez wnioskodawcę pytanie, „czy w świetle normatywnych treści zawartych w powołanych w przedmiotowej sprawie jako wzorce kontroli art. 187 ust. 1 pkt 2 i ust. 4 W ZW. z art. 2, art. 10 ust. 1 i art. 173 Konstytucji oraz art. 186 ust. 1 Konstytucji RP dopuszczalne jest unormowanie przewidujące powoływanie sędziów wchodzących w skład KRS przez inny podmiot niż samo środowisko sędziowskie”.

Zdaniem Sejmu, art. 9a ust. 1 uKRS jest zgodny z art. 186 ust. 1 oraz z art. 187 ust. 1 pkt 2 i ust. 4 w związku z art. 2, art. 10 ust. 1 i art. 173 Konstytucji.

\section{- 2. Kwestia zgodności art. 44 ust. 1 uKRS, w zakresie, w jakim dopuszcza odwołanie od uchwał Krajowej Rady Sądownictwa w sprawach, o których mowa w art. 3 ust. 1 pkt 1 i 2 tej ustawy, z art. 2, art. 10, art. 144 ust. 3 pkt 17, art. 173, art. 178, art. 179 i art. 186 ust. 1 Konstytucji}

Na podstawie art. 44 ust. 1 uKRS uczestnicy postępowania mogą odwołać się do Sądu Najwyższego od uchwał dotyczących przedstawienia Prezydentowi RP wniosków o powołanie sędziów w sądach powszechnych, sądach administracyjnych i sądach wojskowych oraz o powołanie asesorów sądowych w sądach administracyjnych (art. 3 ust. 1 pkt 2 uKRS) i związanej z tym procedury polegającej 
na rozpatrywaniu i ocenie kandydatów do pełnienia urzędu na stanowiskach sędziowskich w sądach powszechnych, sądach administracyjnych i sądach wojskowych oraz na stanowiskach asesorów sądowych w sądach administracyjnych (art. 3 ust. 1 pkt 1 uKRS).

Ustanowiony w art. 44 ust. 1 uKRS środek prawny w postaci umożliwienia uczestnikowi postępowania przed Krajową Radą Sądownictwa zakwestionowania uchwały KRS podjętej w indywidualnej sprawie, ma swoją genezę w wyroku Trybunału Konstytucyjnego z 27 maja 2008 r., sygn. akt SK 57/06, w którym przedmiotem kontroli był aktualnie już nieobowiązujący art. 13 ust. 2 zdanie drugie ustawy z dnia 27 lipca 2001 r. o Krajowej Radzie Sądownictwa, który wyłączał, w sprawach określonych w obecnie nieobowiązującym już art. 2 ust. 1 pkt 2, 3 i 6 tej ustawy możliwość odwołania się od uchwały KRS do Sądu Najwyższego przez sędziego albo osobę, której praw lub obowiązków dotyczyła taka uchwała, wydana w indywidualnej sprawie. Zatem możliwość odwołania się do Sądu Najwyższego była wyłączona $\mathrm{z}$ mocy art. 13 ust. 2 zdanie drugie uKRS w odniesieniu do: 1) uchwał podjętych w wyniku rozpatrzenia i oceny kandydatury do pełnienia urzędu sędziowskiego na stanowiskach sędziów Sądu Najwyższego i Naczelnego Sądu Administracyjnego oraz na stanowiska sędziowskie w sądach powszechnych, wojewódzkich sądach administracyjnych i w sądach wojskowych (art. 2 ust. 1 pkt 2 uKRS); 2) uchwał w sprawie przedstawienia Prezydentowi RP wniosków o powołanie sędziów w Sądzie Najwyższym, Naczelnym Sądzie Administracyjnym, sądach powszechnych, wojewódzkich sądach administracyjnych i sądach wojskowych (art. 2 ust. 1 pkt 3 uKRS) oraz 3) uchwał w sprawie wyboru rzecznika dyscyplinarnego sędziów sądów powszechnych (art. 2 ust. 1 pkt 6 uKRS).

W wyroku z 27 maja 2008 r., sygn. akt SK 57/06 Trybunał Konstytucyjny odniósł się do jeszcze wcześniejszej ustawy, stwierdził mianowicie, że „na gruncie poprzednio obowiązującej ustawy o Krajowej Radzie Sądownictwa, tj. ustawy z dnia 20 grudnia 1989 r. (Dz. U. Nr 73, poz. 435, ze zm.) o możliwości odwoływania się od uchwał Krajowej Rady Sądownictwa w sprawach indywidualnych przesądziło orzecznictwo Sądu Najwyższego oraz Naczelnego Sądu Administracyjnego. Sąd Najwyższy w uchwale z 23 lipca 1992 r., sygn. akt III AZP 9/92 (OSNC nr 7-8/1994, poz. 147) stwierdził, że od uchwały Rady, rozstrzygającej o przeniesieniu sędziego na inne miejsce służbowe ze względu na powagę stanowiska, przysługuje zainteresowanemu skarga do Naczelnego Sądu Administracyjnego. W uzasadnieniu Sąd Najwyższy wskazał, że skład osobowy KRS i jej ustawowe kompetencje są na tyle zróżnicowane, że uniemożliwiają jednoznaczne zakwalifikowanie tego organu do kategorii ośrodków władzy, administracji lub samorządu. Sąd Najwyższy uznał jednak, że KRS stanowi część systemu podmiotów wyposażonych przez ustawę w kompetencje do prowadzenia działalności organizatorskiej i administrującej zarówno wewnątrz systemu wymiaru sprawiedliwości, jak i w stosunku do osób i organów usytuowanych poza tym 
systemem. Uchwały Rady w sprawach dotyczących indywidualnych spraw pracowniczych w resorcie wymiaru sprawiedliwości »zapadają w pewnym szczególnym postępowaniu administracyjnym «, a postępowanie Rady w tych sprawach odpowiada kryteriom postępowania administracyjnego. Wspomniana uchwała Sądu Najwyższego, jak i późniejsze orzecznictwo Sądu Najwyższego oraz Naczelnego Sądu Administracyjnego, podtrzymujące zawartą w niej interpretację, spotkały się z licznymi opiniami krytycznymi opierającymi się na stwierdzeniu, że, ze względu na usytuowanie wśród innych naczelnych organów państwowych oraz kompetencje, KRS była organem władzy sądowniczej sensu largo i wobec tego nie można traktować jej jako organu administracji, którego działania podlegają kontroli sądu administracyjnego" (wyrok TK z 27 maja 2008 r., sygn. akt SK 57/06).

W dalszej części cytowanego uzasadnienia Trybunał Konstytucyjny stwierdził, że: „w tego typu sprawach, jak przedstawianie Prezydentowi Rzeczypospolitej Polskiej wniosków określonych w art. 2 ust. 1 pkt 3 ustawy o KRS, Krajowa Rada Sądownictwa działa jako organ administracyjny wydający decyzję w indywidualnych sprawach. Nie znaczy to wszakże, że przy realizacji wszystkich zadań, czy też we wszystkich formach działania, KRS działa jako organ administracyjny. Analiza wszystkich zadań oraz form działania KRS (art. 2 ust. 2 pkt 1-10) skłaniać może do wniosków, że Rada działa również jako organ samorządu sędziowskiego czy też organ opiniodawczy dla Prezydenta Rzeczypospolitej Polskiej oraz innych organów władzy publicznej. Status prawny KRS jest więc na gruncie ustawy, co wynika z założeń Konstytucji, niejednolity i trudny do jednoznacznego zakwalifikowania. Nie ma to jednak większego znaczenia dla omawianego problemu i rozpatrywanej sprawy. Zdaniem Trybunału, w zakresie realizacji »zadania « określonego w art. 2 ust. 1 pkt 3 ustawy o KRS Krajowa Rada Sądownictwa działa jako organ administracji i mieści się z tego punktu widzenia w pojęciu »organu administracji publicznej«, o którym mowa w art. 79 ust. 1 Konstytucji” (wyrok TK z 27 maja 2008 r., sygn. akt SK 57/06).

Trybunał Konstytucyjny w cytowanym wyroku z 27 maja 2008 r. nie podzielił stanowiska Marszałka Sejmu, „wedle którego odwołanie od uchwał w sprawach wskazanych w art. 13 ust. 2 zdaniu drugim ustawy o KRS nie mieści się w zakresie przedmiotowym terminu »sprawa«, którym posługuje się art. 45 ust. 1 Konstytucji. Zdaniem Marszałka, chodzi tutaj o sprawę wynikającą z podległości służbowej, a konkretnie o kwestię awansu służbowego, w związku z czym sprawa ta nie podlega ocenie sądu, lecz »dyskrecjonalnej władzy pracodawcy«. Postępowanie w sprawie oceny kandydata do pełnienia urzędu sędziowskiego na określonym stanowisku sędziowskim wpływa bezpośrednio na określenie sytuacji prawnej tej osoby. Nie można uznać, że kwestie powołania na określone stanowisko sędziowskie to sprawy z zakresu podległości służbowej. Ubieganie się o stanowisko sędziowskie nie jest zagadnieniem mieszczącym się w treści istniejącego stosunku pracy. Kandydat ubiegający się o stanowisko sędziego 
uczestniczy w procedurze "zewnętrznej « wobec istniejących do tej pory relacji służbowych; ocena jego kandydatury, będąca warunkiem powołania na stanowisko sędziowskie, dokonywana jest przez organ zewnętrzny w stosunku do sądu, w którym dotychczas funkcjonuje. Wynika to już z samej regulacji konstytucyjnej umiejscawiającej KRS na zewnątrz systemu sądów powszechnych, administracyjnych i wojskowych, jako organ, który stoi na straży niezależności sądów (art. 186 ust. 1), jednak nie sprawuje wymiaru sprawiedliwości (art. 175 oraz art. 177 Konstytucji). Po doręczeniu sędziemu aktu powołania zostaje nawiązany nowy w swej treści stosunek służbowy [...]. Ponadto zaskarżona regulacja odnosi się także do osób niepełniących jeszcze urzędu sędziowskiego na żadnym stanowisku. Zdaniem Trybunału, ani szczególna, konstytucyjna, pozycja ustrojowa KRS, ani fakt, że w myśl art. 12 ust. 5 ustawy o KRS w postępowaniu przed Radą nie stosuje się przepisów kodeksu postępowania administracyjnego, nie odbierają postępowaniu przed Radą w sprawach indywidualnych, dotyczących powołania na stanowiska sędziowskie, charakteru postępowania administracyjnego. Przedmiot postępowania $\mathrm{w}$ kwestii oceny kandydata i przedstawienia wniosku o jego powołanie na stanowisko sędziego ma charakter sprawy $\mathrm{w}$ rozumieniu art. 45 ust. 1 Konstytucji. I jako taka powinna podlegać kontroli sądowej w zakresie właściwym tego rodzaju sprawom, tj. pod kątem legalności, przestrzegania stosownych procedur prawnych. Zgodzić się natomiast należy ze stanowiskiem, że merytoryczna ingerencja sądu w rozstrzygnięcia Rady byłaby niedopuszczalna, wkraczałaby bowiem w sferę szczególnego władztwa Rady, wynikającego $\mathrm{z}$ samych norm konstytucyjnych. Jednakże kontrola sądowa przestrzegania praw obywateli, w rozważanym wypadku praw wynikających $\mathrm{z}$ art. 60 Konstytucji, tj. prawa równego dostępu do służby publicznej, a zatem w sprawach prowadzenia naboru na podstawie przejrzystych kryteriów selekcji kandydatów i obsadzania poszczególnych stanowisk w służbie publicznej, jest, w myśl art. 45 ust. 1 Konstytucji, konieczna" (wyrok TK z 27 maja 2008 r., sygn. akt SK 57/06).

Wnioskodawca podnosi, że w obowiązującej ustawie o KRS, w przeciwieństwie do nieobowiązującego już art. 13 ust. 5 uKRS „nie uregulowano kwestii związanych z orzeczeniami, które wydaje Sąd Najwyższy po rozpoznaniu sprawy w wyniku odwołania od uchwały Rady. W związku z tym odpowiednie zastosowanie będą miały art. $398^{14}$ k.p.c., stanowiący podstawę oddalenia skargi kasacyjnej oraz art. $398^{15}$ k.p.c., dotyczący uchylenia zaskarżonego orzeczenia i przekazania sprawy do ponownego rozpoznania, w tym przypadku Krajowej Radzie Sądownictwa. Wyłączone jest stosowanie art. $398^{16}$ k.p.c., dającego Sądowi Najwyższemu podstawę do wydania wyroku reformatoryjnego" (wniosek, s. 34).

W przypadku uwzględnienia odwołania Sąd Najwyższy uchyla zaskarżoną uchwałę w całości lub w części i przekazuje sprawę do ponownego rozpoznania Krajowej Radzie Sądownictwa.

W orzecznictwie Sądu Najwyższego przyjmuje się, że przedmiotem kontroli jest formalny aspekt dostępu do służby, dotyczący przestrzegania przez KRS 
przyjętych kryteriów i procedur postepowania, nie zaś sama ocena kwalifikacji czy predyspozycji danej osoby, ponieważ mogłoby to naruszać uprawnienia i kompetencje KRS wynikające $z$ art. 179 Konstytucji i z art. 3 ust. 1 pkt 1 i 2 uKRS (wyroki SN z: 13 lipca 2017 r., sygn. akt III KRS 17/17; 7 marca 2017 r., sygn. akt III KRS 3/17; 26 stycznia 2017 r., sygn. akt III KRS 37/16).

Jak wskazuje wnioskodawca, „Sąd Najwyższy zastrzega, że ocena doboru kryteriów oraz znaczenie przywiązywane do poszczególnych kryteriów przy ocenie kandydatów na stanowiska sędziowskie pozostają poza zakresem kompetencji Sądu Najwyższego do kontroli zgodności uchwał Rady z prawem (art. 44 ust. 1 ustawy o Krajowej Radzie Sądownictwa), chyba że naruszają podstawowe zasady prawne lub opierają się na zastosowaniu niedozwolonych kryteriów oceny. [...] Kierunek rozwoju poglądu Sądu Najwyższego świadczy o tym, że nie wyklucza on, że w określonych przypadkach mógłby ocenić zasadność i sposób wyznaczenia kryteriów dla kandydatów na urząd sędziego, a takie działanie zbliża się niebezpiecznie do ingerencji w konstytucyjnie ukształtowany status Krajowej Rady Sądownictwa w zakresie dotyczącym procedury powoływania sędziów" (wniosek, s. 35).

Sejm zgadza się z poglądem wnioskodawcy, który wskazuje na problemy konstytucyjne wynikające z zaskarżonego art. 44 ust. 1 uKRS w zakresie, w jakim dopuszcza odwołanie od uchwał Krajowej Rady Sądownictwa w sprawach, o których mowa w art. 3 ust. 1 pkt 1 i 2 uKRS. Chodzi mianowicie o „dysfunkcjonalność stworzonej instytucji, ingerencję w zasadę podziału i równowagi władz poprzez dopuszczenie niedozwolonego wpływu władzy sądowniczej na proces nominacji sędziów, a przez to naruszenie zasady niezależności sądów i niezależności sędziów" (ibidem, s. 35).

Zdaniem Sejmu wnioskodawca przedstawił przekonujące argumenty na poparcie swoich zarzutów. W szczególności Sejm podziela zarzut wnioskodawcy, że analizowana instytucja odwołania od uchwał KRS do Sądu Najwyższego, „mimo że została ukształtowana w wyniku wyroku TK zobowiązującego do zapewnienia kontroli procedur dostępu do służby publicznej na jednakowych zasadach, jest rozwiązaniem dysfunkcjonalnym, przez co utrudnia realizację konstytucyjnych uprawnień organów władzy publicznej. Praktyka pokazuje, że w znakomitej większości przypadków odwołania są oddalane, a Sąd nie dysponuje normatywnymi narzędziami do dokonania właściwej weryfikacji tylko pod względem dopełnienia kwestii formalnych bez wchodzenia w kwestie merytoryczne dotyczące kryteriów oceny sędziów. W ten sposób orzekanie w sprawie może być daleko uznaniowe, a nawet arbitralne. Również zakres kognicji Sądu Najwyższego, zakreślony przez TK w wyroku o sygn. SK 57/05, ogranicza w sposób znaczący skuteczność i celowość weryfikacji realizacji prawa dostępu do służby publicznej. Oznacza to, że w istocie - mimo istnienia formalnej procedury - mamy do czynienia $z$ instytucją dysfunkcjonalną i pozorną, a taki stan rzeczy jest niezgodny z art. 2 i art. 7 Konstytucji RP” (ibidem, s. 36). 
Godny wzięcia pod rozwage jest także argument wnioskodawcy, że „część aktualnych wypowiedzi SN świadczy o tym, że w pewnych przypadkach sąd ten - w ramach kontroli spełnienia wymogów konstytucyjnych - byłby zdolny do weryfikacji kryteriów oceny kandydatów na sędziów oraz sposobu ich przypisania w konkretnej sprawie. Wejście w ocenę merytoryczną decyzji Krajowej Rady Sądownictwa bez wyraźnej podstawy prawnej jest naruszeniem zasady legalizmu (art. 7 Konstytucji RP), a także ingeruje w konstytucyjnie ukształtowane kompetencje KRS do wnioskowania o powołanie sędziów, a przez to wpływa na realizację kompetencji do powoływania sędziów przez Prezydenta RP. Dzięki odwołaniu Sąd Najwyższy w pewnych wypadkach może bowiem narzucić określony sposób działania KRS, gdyż w orzecznictwie SN pojawia się nierzadko stanowisko, że gdy Sąd ten przekaże Radzie sprawę do ponownego rozpoznania, Rada jest związana stanowiskiem sądu, zgodnie z przepisami Kodeksu postępowania cywilnego. To oznacza, że możliwość odwołania od uchwał KRS w zakwestionowanym zakresie stanowi nieadekwatną i nieproporcjonalną ingerencję w konstytucyjne kompetencje Prezydenta RP i Krajowej Rady Sądownictwa. Przez to naruszona jest nie tylko wynikająca $\mathrm{z}$ art. 2 Konstytucji zasada proporcjonalności, ale także zasada podziału i równowagi władzy (art. 10 Konstytucji RP) i konstytucyjne przepisy o powoływaniu sędziów (art. 179 i art. 144 ust. 3 pkt 17 Konstytucji RP)" (ibidem, s. 36-37).

Sejm przychyla się do argumentacji wnioskodawcy, który podkreśla, że przyznanie prawa do analizowanego odwołania od uchwały KRS „zostało oparte na przekonaniu, że uchwała KRS powoduje, że mamy do czynienia ze sprawą z zakresu administracji publicznej. Tymczasem, nie można o postępowaniu przed Krajową Radą Sądownictwa mówić jako o postępowaniu przed organem administracji publicznej. KRS nie jest organem administracji publicznej, ale jest konstytucyjnym organem państwa nienależącym do władzy wykonawczej i niewykonującym zadań z zakresu administracji publicznej. Stąd wprowadzenie uproszczenia w tym zakresie, przez które uzasadnia się określone działania legislacyjne, stoi w sprzeczności z konstytucyjną pozycją Krajowej Rady Sądownictwa. Sprowadzenie tego organu do organu administracyjnego, a postępowania przed nim do postępowania administracyjnego (mimo że ustawa wyraźnie wskazuje, że przepisów Kodeksu postępowania administracyjnego się w tym przypadku nie stosuje) narusza konstytucyjne przepisy o ustroju KRS i powoduje, że ogranicza się jej możliwość działania w ramach stania na straży niezależności sądów i niezawisłości sędziów" (ibidem, s. 37).

Konkludując, Sejm uznaje za przekonujące i uzasadnione zarzuty wnioskodawcy, wobec czego wnosi o stwierdzenie, że art. 44 ust. 1 uKRS w zakresie, w jakim dopuszcza odwołanie od uchwał Krajowej Rady Sądownictwa w sprawach, o których mowa w art. 3 ust. 1 pkt 1 i 2 tej ustawy, jest niezgodny z art. 2, art. 10, art. 144 ust. 3 pkt 17, art. 173, art. 178, art. 179 i art. 186 ust. 1 Konstytucji. 


\section{Kwestia zgodności art. 44 ust. 1 a uKRS z art. 2, art. 10, art. 60,} art. 144 ust. 3 pkt 17, art. 173, art. 178, art. 179 i art. 184 Konstytucji Artykuł 44 ust. 1a uKRS został dodany na mocy ustawy z dnia 8 grudnia 2017 r. o zmianie ustawy o Krajowej Radzie Sadownictwa oraz niektórych innych ustaw (Dz. U. 2018, poz. 3). Celem tej regulacji było uniemożliwienie oceny przez Sąd Najwyższy uchwał KRS w sprawach przedstawienia kandydatów na sędziów Sądu Najwyższego. Przepis ten wprowadza mechanizm odwoławczy do Naczelnego Sądu Administracyjnego w odniesieniu do spraw indywidualnych dotyczących powołania do pełnienia urzędu na stanowisku sędziego Sądu Najwyższego.

Wnioskodawca podnosi, że do Naczelnego Sądu Administracyjnego wpływają odwołania od uchwał KRS, a NSA zastosował już w kilku sprawach art. $388 \$ 1$ k.p.c., postanawiając wstrzymać wykonanie skarżonych uchwał KRS (zob. postanowienia NSA z: 25 września 2018 r., sygn. akt II GW 23/18; 25 września 2018 r., sygn. akt II GW 22/18). Wobec tego „poprzez instytucję odwołania od uchwał KRS do Naczelnego Sądu Administracyjnego, Sąd ten podejmuje rozstrzygnięcia dotyczące ustrojowej procedury, jaką jest proces powoływania sędziów" (wniosek, s. 39).

Sejm podziela zdanie wnioskodawcy, który wskazuje, że problemy konstytucyjne wynikające z art. 44 ust. 1a uKRS „obejmują dysfunkcjonalność stworzonej instytucji, naruszenie określoności prawa, a także są związane $\mathrm{z}$ ingerencją w zasadę podziału i równowagi władzy poprzez dopuszczenie niedozwolonego wpływu władzy sądowniczej na proces nominacji sędziów, a przez to naruszenie zasady niezależności sądów i niezależności sędziów. Dodatkowo przepisy budzą wątpliwość co do ich zgodności z konstytucyjną pozycją Naczelnego Sądu Administracyjnego i jego kompetencjami” (ibidem).

Zdaniem Sejmu wnioskodawca trafnie podnosi, że jeśli ustawodawca konstytucyjny powierzył daną kompetencję określonym podmiotom, a mianowicie kompetencję KRS do przedstawienia wniosku oraz kompetencję Prezydentowi RP do dokonania aktu powołania, to należy z tej perspektywy oceniać dopuszczalny zakres regulacji ustawowej tej materii. Stworzenie procedury odwoławczej do NSA włącza ten sąd w proces decyzyjny związany z powoływaniem sędziów. Ponieważ zakres odwołania jest sformułowany w sposób nieostry, co powoduje, że może być doprecyzowany w procesie stosowania prawa, w rezultacie sprawia, że taka regulacja stanowi nieproporcjonalną ingerencję w konstytucyjną prerogatywę Prezydenta RP i w uprawnienia KRS do przedkładania wniosku w sprawie powołania na urząd sędziowski.

Wnioskodawca powołuje się na pierwsze postanowienia NSA o zawieszeniu wykonania uchwał, które „pokazują, że w praktyce przepis ten może mieć charakter hamujący konstytucyjne procedury powoływania sędziów, przez co dochodzi do dysfunkcji systemu organów władzy publicznej. Wskazane działanie nie jest proporcjonalne i nie realizuje założonego celu, którym miała być ochrona prawa dostępu do służby publicznej na równych zasadach” (ibidem, s. 40). 
Wnioskodawca trafnie podnosi, że: „sposób sformułowania przepisu nie daje odpowiedzi, w jaki sposób powinna być przez Naczelny Sąd Administracyjny badana uchwała KRS, aby nie naruszać konstytucyjnego podziału kompetencji organów. To wprowadza poczucie niepewności prawnej i brak stabilności systemu prawa. Daje też szeroki margines swobody sądowi administracyjnemu do działania, co powoduje ryzyko, że w pewnych przypadkach będzie on podejmował rozstrzygnięcia bez podstawy prawnej. Z tego względu wskazane przepisy należy ocenić jako naruszające art. 2 i art. 7 Konstytucji RP” (ibidem).

Sejm zgadza się z wnioskodawcą, który zarzuca, że włączenie NSA w proces powoływania sędziów sprawia, że art. 44 ust. 1a uKRS stanowi nadmierną ingerencję w zasadę podziału i równowagi władzy, a także niewspółmiernie ingeruje w zasadę niezależności sądów, które zostają włączone, bez podstawy konstytucyjnej, w ustrojowy proces powoływania sędziów.

Trafny jest także, zdaniem Sejmu, zarzut wnioskodawcy, że art. 44 ust. 1a uKRS „różnicuje środki weryfikacji uchwał KRS dotyczących przedstawiania kandydatów na stanowisko sędziego w zależności od tego, czy mamy do czynienia $z$ kandydatem do Sądu Najwyższego, czy do innego sądu. W przypadku kandydatów do SN właściwy jest Naczelny Sąd Administracyjny, w pozostałych przypadkach odwołania rozpoznaje Sąd Najwyższy. Wprowadzanie różnych reżimów w tym zakresie stoi w sprzeczności z prawem dostępu do służby publicznej na jednakowych zasadach w kontekście jednakowych procedur weryfikacji aktów KRS. Przez to ustawodawca wprowadza różne standardy gwarancji proceduralnych w procesie powoływania sędziów, co stoi w sprzeczności z prawami konstytucyjnymi" (ibidem, s. 41).

Sejm przychyla się także do stwierdzenia wnioskodawcy, że powierzenie weryfikacji uchwał KRS w zakresie wynikającym z art. 44 ust. 1a uKRS sądowi administracyjnemu czyni z postępowania przed KRS, dotyczącego wyłaniania kandydatów na sędziego, sui generis postępowanie administracyjne. Wnioskodawca słusznie nie zgadza się z przyjętą przez TK w sprawie o sygn. akt SK 57/06 wykładnią, że postępowanie to dotyczy spraw z zakresu administracji publicznej, a kwestia przedstawienia albo nieprzedstawienia kandydata na stanowisko sędziego Prezydentowi RP jest sprawą z zakresu administracji publicznej. W przeciwieństwie do tego poglądu wnioskodawca stwierdza, że kompetencje KRS w zakresie oceny kandydatów i ich przedstawiania Prezydentowi RP mają charakter ustrojowy, wobec czego art. 44 ust. 1a uKRS narusza przypisane sądom administracyjnym zadania, które wynikają z art. 184 Konstytucji.

Konkludując, Sejm wnosi o stwierdzenie, że art. 44 ust. 1a uKRS jest niezgodny $z$ art. 2 , art. 10, art. 60, art. 144 ust. 3 pkt 17, art. 173, art. 178, art. $179 \mathrm{i}$ art. 184 Konstytucji. 
- 4. Kwestia zgodności art. 44 ust. 3 uKRS w związku z art. 388 § 1 k.p.c. w zakresie, w jakim umożliwia wstrzymanie uprawnień Prezydenta Rzeczypospolitej Polskiej do powołania sędziego, z art. 2, art. 7, art. 10, art. 144 ust. 3 pkt 17, art. 173, art. 178, art. 179 i art. 184 Konstytucji

Przystępując do rozważenia kwestii zgodności art. 44 ust. 3 uKRS w związku $\mathrm{z}$ art. $388 \$ 1$ k.p.c. w zakresie, w jakim umożliwia wstrzymanie uprawnień Prezydenta Rzeczypospolitej Polskiej do powołania sędziego, z powołanymi wzorcami konstytucyjnymi, Sejm sygnalizuje pewną wątpliwość, czy zarzut sformułowany przez wnioskodawcę w punkcie piątym petitum wniosku nie wykracza poza legitymację wnioskową Krajowej Rady Sądownictwa, która zgodnie z art. 186 ust. 2 Konstytucji może wystąpić do TK z wnioskiem w sprawie zgodności z Konstytucją aktów normatywnych w zakresie, w jakim dotyczą one niezależności sądów i niezawisłości sędziów. W przypadku analizowanego zarzutu problem dotyczy wprost uprawnień Prezydenta RP, choć pośrednio nie jest wykluczone, że może oddziaływać na kwestię niezależności sądów lub niezawisłości sędziów.

Zgodnie z treścią art. $388 \$ 1$ k.p.c. w przypadku wniesienia skargi kasacyjnej, gdyby na skutek wykonania orzeczenia stronie mogła być wyrządzona niepowetowana szkoda, sąd drugiej instancji może wstrzymać wykonanie zaskarżonego orzeczenia do czasu ukończenia postępowania kasacyjnego lub uzależnić wykonanie tego orzeczenia (w przypadku oddalenia apelacji także orzeczenia sądu pierwszej instancji) od złożenia przez powoda stosowanego zabezpieczenia.

Ponieważ art. 44 ust. 3 uKRS nakazuje do postępowania przed SN i NSA stosować przepisy Kodeksu postępowania cywilnego o skardze kasacyjnej, nie można wykluczyć, że NSA zastosuje do postępowania w sprawie rozpatrywania odwołań od uchwał KRS przepis art. $388 \$ 1$ k.p.c., umożliwiający wstrzymanie wykonania zaskarżonego orzeczenia.

Jak podnosi wnioskodawca, „wskazany przepis odnosi się wprawdzie do orzeczenia, ale uznano, że skoro do odwołań od uchwał KRS stosuje się przepisy k.p.c. o skardze kasacyjnej, to także ten przepis będzie miał zastosowanie, z tym, że należy go czytać w taki sposób, że zamiast orzeczenia mamy do czynienia z uchwałą. Zastosowanie tej normy miało miejsce w praktyce, choć do postanowień NSA zostało złożone zdanie odrębne (zob. postanowienie NSA z dnia 25 września 2018 r., II GW 23118; postanowienie NSA z dnia 25 września 2018 r., II GW 22118), co oznacza, że obowiązuje ona w obrocie prawnym i może być przedmiotem kontroli przed Trybunałem Konstytucyjnym” (wniosek, s. 46).

Sejm zgadza się z argumentacją wnioskodawcy, który wskazuje na problem konstytucyjny wynikający ze skarżonej normy, który polega na tym, że przy jej pomocy NSA „może władczo oddziaływać na procedurę powoływania sędziów, co stoi w sprzeczności z konstytucyjnymi przepisami dotyczącymi tego zagadnienia. Ponadto regulacja ta stanowi naruszenie zasad państwa prawnego związanych z zasadami racjonalności ustawodawcy oraz spójności i określoności 
prawa. Wreszcie oddziałuje ona na pozycję ustrojową tak NSA, jak i Krajowej Rady Sądownictwa w kontekście koncepcji podziału i równowagi władzy. Z tego względu zarysowana kompetencja budzi też wątpliwość co do jej zgodności z zasadą niezależności sądów, a w konsekwencji, jako że dotyczy powoływania sędziów, także z niezależnością sędziów" (ibidem).

Wnioskodawca zarzuca, że „przyznanie uchwale KRS przymiotu orzeczenia $\mathrm{w}$ rozumieniu art. $388 \$ 1$ k.p.c. powoduje, że wbrew ustrojowemu znaczeniu aktu Rady wynikającemu z art. 179 Konstytucji RP, uchwała taka staje się aktem wiążącym Prezydenta RP. To zaś stoi w sprzeczności z przepisami konstytucyjnymi dotyczącymi powoływania sędziów (art. 179, art. 144 ust. 3 pkt 17 Konstytucji), a także z elementarnymi wymogami zasady podziału i równowagi władzy (art. 10 Konstytucji RP) i niezależności sądów (art. 173 Konstytucji RP)" (ibidem, s. 47).

Ponadto należy zgodzić się z argumentem wnioskodawcy, że „skoro sprawa powoływania sędziów (w tym przedstawiania Prezydentowi RP kandydatów na urząd sędziowski) ma charakter publicznoprawny, to nie towarzyszy jej ryzyko sytuacji, o której mowa w art. $388 \$ 1$ k.p.c., która stanowiłaby przesłankę jego stosowania. Należy zatem uznać, że dopuszczenie do funkcjonowania w obrocie prawnym skarżonej normy powoduje naruszenie przepisów konstytucyjnych dotyczących pozycji ustrojowej Naczelnego Sądu Administracyjnego" (ibidem, s. 47-48).

Konkludując, Sejm wnosi o uznanie, że art. 44 ust. 3 uKRS w związku $\mathrm{z}$ art. $388 \$ 1$ k.p.c. w zakresie, w jakim umożliwia wstrzymanie uprawnień Prezydenta Rzeczypospolitej Polskiej do powołania sędziego, jest niezgodny z art. 2, art. 7, art. 10, art. 144 ust. 3 pkt 17, art. 173, art. 178, art. 179 i art. 184 Konstytucji.

- 5. Kwestia zgodności art. 44 ust. 4 uKRS z art. 2, art. 7, art. 10, art. 60, art. 173 , art. 178 , art. 179 i art. 186 ust. 1 Konstytucji

Przystępując do rozważenia kwestii zgodności art. 44 ust. 4 uKRS z art. 2, art. 7, art. 10, art. 60, art. 173, art. 178, art. 179 i art. 186 ust. 1 Konstytucji, Sejm sygnalizuje pewną wątpliwość, czy zarzut sformułowany przez wnioskodawcę w punkcie szóstym petitum wniosku nie wykracza poza legitymację wnioskową Krajowej Rady Sądownictwa. W szczególności w odniesieniu do art. 60 Konstytucji, uwzględniając treść sformułowanego zarzutu, należy podnieść wątpliwość, czy KRS przysługuje zdolność wnioskowa. Warto zwrócić uwagę, czy analizowana regulacja prowadzi do naruszenia niezależności sądów i niezawisłości sędziów. Ze względu na to, że być może w sposób pośredni oddziałuje na kwestię niezależności sądów lub niezawisłości sędziów, Sejm uznaje za zasadne merytoryczne rozważenie tego zarzutu.

Artykuł 44 ust. 4 uKRS dotyczy konsekwencji uchylenia przez NSA uchwały KRS o nieprzedstawieniu wniosku o powołanie do pełnienia urzędu sędziego Sądu Najwyższego. Uchylenie to jest równoznaczne z przyjęciem zgłoszenia, a je- 
śli procedura już się zakończyła, z przyjęciem zgłoszenia na kolejne wolne stanowisko sędziowskie w Sądzie Najwyższym objętego obwieszczeniem.

Przewidziana w art. 44 ust. 4 uKRS procedura pozwala osobie, która uzyskała korzystne dla siebie rozstrzygnięcie NSA, uczestniczyć w procesie powoływania sędziów na innych, niż pozostałe osoby zgłaszające swoją kandydaturę, zasadach. W szczególności dotyczy to przypadku związanego z obwieszczeniem o nowym wolnym stanowisku.

Zdaniem Sejmu wnioskodawca przedstawił przekonujące argumenty przemawiające za niekonstytucyjnością art. 44 ust. 4 uKRS. Przepis ten włącza NSA w proces powoływania sędziów SN i przyznaje NSA władcze kompetencje w tym zakresie. Zakwestionowana regulacja powoduje, że treść wniosku KRS do Prezydenta RP w sprawie przedstawienia kandydata na stanowisko sędziego SN jest kształtowana przez NSA, co narusza art. 179 i art. 144 ust. 3 pkt 17 Konstytucji.

Sejm przychyla się także do argumentu wnioskodawcy, że: „rozstrzygnięcie NSA ingeruje w autonomiczną decyzję Krajowej Rady Sądownictwa, która zgodnie $\mathrm{z}$ zasadami konstytucyjnymi nie możne być kształtowana przez inny organ (art. 186 ust. 1 Konstytucji RP, art. 10 Konstytucji RP). Jeżeli we współkształtowaniu wniosku Krajowej Rady Sądownictwa do Prezydenta RP bierze udział NSA, oznacza to, że dochodzi do naruszenia ustrojowej pozycji KRS, która na mocy Konstytucji jako wyłączny organ jest kompetentna przedłożyć Prezydentowi stosowny wniosek i jest to organ stojący na straży niezależności sądów i niezawisłości sędziów. W ten sposób dochodzi do nieproporcjonalnej ingerencji w konstytucyjne uprawnienia organów państwa w zakresie dotyczącym procedury powoływania sędziów Sądu Najwyższego (art. 2 Konstytucji RP)" (wniosek, s. 49-50).

Również kolejny argument wnioskodawcy, zdaniem Sejmu, zasługuje na aprobatę. Mianowicie wnioskodawca słusznie podnosi, że „norma wynikająca z przepisu art. 44 ust. 4 ustawy o Krajowej Radzie Sądownictwa pozwala na obejście przepisów dotyczących procedury zgłaszania kandydatów na stanowisko sędziego Sądu Najwyższego, co powoduje, że dochodzi do naruszenia zasady równości w dostępie do służby publicznej (art. 60 Konstytucji RP). Przepis art. 44 ust. 4 ustawy o KRS różnicuje bowiem podmioty podobne, w uprzywilejowany sposób traktując tych kandydatów, którzy uzyskali pozytywne w swojej sprawie rozstrzygnięcie NSA" (ibidem, s. 50).

W kontekście przytoczonych argumentów Sejm wnosi o stwierdzenie, że art. 44 ust. 4 uKRS jest niezgodny z art. 2, art. 7, art. 10, art. 60, art. 173, art. 178, art. $179 \mathrm{i}$ art. 186 ust. 1 Konstytucji.

Podsumowując poczynione uprzednio rozważania, Sejm wnosi o uznanie, że:

- art. 9a ust. 1 uKRS jest zgodny z art. 186 ust. 1 oraz z art. 187 ust. 1 pkt 2 i ust. 4 w związku z art. 2, art. 10 ust. 1 i art. 173 Konstytucji,

- art. 44 ust. 1 uKRS w zakresie, w jakim dopuszcza odwołanie od uchwał Krajowej Rady Sądownictwa w sprawach, o których mowa w art. 3 ust. 1 pkt 1 
i 2 tej ustawy, jest niezgodny z art. 2, art. 10, art. 144 ust. 3 pkt 17, art. 173, art. 178 , art. $179 \mathrm{i}$ art. 186 ust. 1 Konstytucji,

- art. 44 ust. 1a uKRS jest niezgodny z art. 2, art. 10, art. 60, art. 144 ust. 3 pkt 17, art. 173, art. 178, art. 179 i art. 184 Konstytucji,

- art. 44 ust. 3 uKRS w związku z art. $388 \$ 1$ k.p.c. w zakresie, w jakim umożliwia wstrzymanie uprawnień Prezydenta Rzeczypospolitej Polskiej do powołania sędziego, jest niezgodny z art. 2, art. 7, art. 10, art. 144 ust. 3 pkt 17, art. 173, art. 178, art. 179 i art. 184 Konstytucji,

- art. 44 ust. 4 uKRS jest niezgodny z art. 2, art. 7, art. 10, art. 60, art. 173, art. 178 , art. 179 i art. 186 ust. 1 Konstytucji.

Sejm wnosi także o umorzenie postępowania w pozostałym zakresie na podstawie art. 59 ust. 1 pkt 2 ustawy z dnia 30 listopada 2016 r. o organizacji i trybie postępowania przed Trybunałem Konstytucyjnym (Dz. U. poz. 2072) ze względu na niedopuszczalność wydania wyroku.

\section{Bibliografia}

Banaszak B., Konstytucja Rzeczypospolitej Polskiej. Komentarz, Warszawa 2009.

Banaszak B., Konstytucja Rzeczypospolitej Polskiej. Komentarz, Warszawa 2012.

Ciapała J., Charakter kompetencji Prezydenta RP. Uwagi w kontekście kompetencji w zakresie powoływania sędziów, „Przegląd Sejmowy” 2008, nr 4.

Complak K., Art. 7. Działanie na podstawie i w granicach prawa [w:] Konstytucja Rzeczypospolitej Polskiej. Komentarz, red. M. Haczkowska, Warszawa 2014.

Garlicki L., Komentarz do art. 178 [w:] Konstytucja Rzeczypospolitej Polskiej. Komentarz, t. IV, red. L. Garlicki, Warszawa 2005.

Garlicki L., Wolności i prawa jednostki w Konstytucji Rzeczypospolitej Polskiej z 1997 r. [w:] Pięć lat Konstytucji Rzeczypospolitej Polskiej. Materiały z konferencji na Zamku Królewskim w Warszawie, 17 października 2002, red. H. Jerzmański,Warszawa 2002.

Kostyk B., Niekonstytucyjność trybu wyboru części członków Krajowej Rady Sądownictwa, „Iustitia” 2015, nr 2.

Kozłowski K., Tuleja P., Ewolucja ustrojowej pozycji sądów a konstytucyjne zadania Krajowej Rady Sądownictwa, „Krajowa Rada Sądownictwa” 2015, nr 1.

Masternak-Kubiak M., Art. 178. Sędziowie; niezawisłość sędziowska [w:] Konstytucja Rzeczypospolitej Polskiej. Komentarz, red. M. Haczkowska, Warszawa 2014.

Pach M., Tuleja P., Art. 10 [w:] Konstytucja RP, t. I, Komentarz. Art. 1-86, red. M. Safjan, L. Bosek, Warszawa 2016.

Potrzeszcz J., Opinia prawna w sprawie zgodności z Konstytucja przedstawionego przez Prezydenta Rzeczypospolitej Polskiej projektu ustawy o zmianie ustawy o Krajowej Radzie Sądownictwa oraz niektórych innych ustaw, http://www.sejm.gov.pl/sejm8.nsf/ opinieBAS.xsp?nr=2002. 
Prawo konstytucyjne Rzeczypospolitej Polskiej, red. P. Sarnecki, Warszawa 2002.

Prawo o ustroju sądów powszechnych. Ustawa o Krajowej Radzie Sądownictwa. Komentarz, red. J. Gudowski, Warszawa 2009.

Sarnecki P., Komentarz do art. 10 [w:] Konstytucja Rzeczypospolitej Polskiej. Komentarz, red. L. Garlicki, M. Zubik, t. I, Warszawa 2016.

Sokolewicz W., Wojtyczek K., Komentarz do art. 60 [w:] Konstytucja Rzeczypospolitej Polskiej. Komentarz, red. L. Garlicki, M. Zubik, t. II, Warszawa 2016.

Szczucki K., Art. 186; Art. 187 [w:] Konstytucja RP, t. II, Komentarz. Art. 87-243, red. M. Safjan, L. Bosek, Warszawa 2016.

Trzciński J., Pojęcie konstytucyjnego organu państwa socjalistycznego (na tle Konstytucji $P R L)$, Wrocław 1974.

Tuleja P., Art. 2; Art. 7 [w:] Konstytucja RP, t. I, Komentarz. Art. 1-86, red. M. Safjan, L. Bosek, Warszawa 2016.

Tuleja P., Konstytucyjny status Krajowej Rady Sadownictwa [w:] Krajowa Rada Sadownictwa. XX-lecie działalności, red. P. Tuleja, Warszawa 2010

Tuleja P., Postepowanie przed Trybunałem Konstytucyjnym w sprawie hierarchicznej kontroli norm, „Przegląd Sejmowy” 2009, nr 5.

Weitz K., Art. 179 [w:] Konstytucja RP, t. II, Komentarz. Art. 87-243, red. M. Safjan, L. Bosek, Warszawa 2016.

Wiącek M., Art. 184 [w:] Konstytucja RP, t. II, Komentarz do art. 87-243, red. M. Safjan, L. Bosek, Warszawa 2016.

Wiliński P., Karlik P., Art. 173; Art. 178 [w:] Konstytucja RP, t. II, Komentarz. Art. 87-243, red. M. Safjan, L. Bosek, Warszawa 2016.

Ziembiński Z., Analiza pojęcia czynu, Warszawa 1972.

Ziółkowski M., Prerogatywa Prezydenta RP do powoływania sędziów (uwagi o art. 144 ust. 3 pkt 17 i art. 179 Konstytucji), „Przegląd Sejmowy” 2013, nr 1. 